UNIVERSIDADE DE SÃO PAULO

INSTITUTO DE PSICOLOGIA

AILTON BEDANI

\title{
A RELAÇÃO ENTRE SENSAÇÃO E PRODUÇÃO DE CONHECIMENTO NA OBRA DE WILHELM REICH
}

São Paulo

2013 


\section{A RELAÇÃO ENTRE SENSAÇÃO E PRODUÇÃO DE CONHECIMENTO NA OBRA DE WILHELM REICH}

(Versão original)

Tese apresentada ao Instituto de Psicologia da Universidade de São Paulo como parte dos requisitos para a obtenção do título de Doutor em Psicologia.

Área de Concentração: Psicologia Escolar e do Desenvolvimento Humano.

Orientador: Prof. Dr. Paulo Albertini.

São Paulo

2013 
AUTORIZO A REPRODUÇÃO E DIVULGAÇÃO TOTAL OU PARCIAL DESTE TRABALHO, POR QUALQUER MEIO CONVENCIONAL OU ELETRÔNICO, PARA FINS DE ESTUDO E PESQUISA, DESDE QUE CITADA A FONTE.

Catalogação na publicação

Biblioteca Dante Moreira Leite

Instituto de Psicologia da Universidade de São Paulo

Bedani, Ailton.

A relação entre sensação e produção de conhecimento na obra de Wilhelm Reich / Ailton Bedani; orientador Paulo Albertini. -- São Paulo, 2013.

$212 \mathrm{f}$.

Tese (Doutorado - Programa de Pós-Graduação em Psicologia. Área de Concentração: Psicologia Escolar e do Desenvolvimento Humano) - Instituto de Psicologia da Universidade de São Paulo.

1. Reich, Wilhelm, 1897-1957 2. Sensação 3. Percepção

4. Epistemologia I. Título.

RC506 


\section{FOLHA DE APROVAÇÃO}

\section{Ailton Bedani \\ “A relação entre sensação e produção de conhecimento na obra de Wilhelm Reich"}

The relation between sensation and knowledge production in the work of Wilhelm Reich

Tese apresentada ao Instituto de Psicologia da Universidade de São Paulo como parte dos requisitos para a obtenção do título de Doutor em Psicologia.

Área de Concentração: Psicologia Escolar e do Desenvolvimento Humano.

Aprovado em:

Banca Examinadora

Prof. Dr.

Instituição:

Assinatura:

Prof. Dr.

Instituição:

Assinatura:

Prof. Dr.

Instituição:

Assinatura:

Prof. Dr.

Instituição:

Assinatura:

Prof. Dr.

Instituição:

Assinatura: 


\title{
DEDICATÓRIA
}

\begin{abstract}
À Nancy Romanelli, pelo companheirismo intenso, fortalecedor e bem-humorado! E pela criteriosa leitura desta tese e preciosos comentários.
\end{abstract}




\section{AGRADECIMENTOS}

É muito reconfortante agradecer por escrito às pessoas que contribuíram para este trabalho, embora eu não tenha certeza de que a listagem abaixo faça jus a todos que, de uma maneira ou de outra, acompanharam o desenvolvimento da pesquisa.

É com esse sentimento de dúvida, mas também com profunda gratidão, que eu gostaria de prestar meus agradecimentos:

Ao prof. Dr. Paulo Albertini, orientador de minha dissertação de mestrado e desta tese, pelo respeito aos caminhos nem sempre lineares da pesquisa e pelas intervenções certeiras. E, uma vez mais, pela ousadia de ter aberto um inovador espaço acadêmico de interlocução com o pensamento reichiano.

Aos profs. Drs. Iray Carone e Claudio Mello Wagner, pela cuidadosa e estimulante apreciação deste trabalho por ocasião do Exame de Qualificação.

Ao Jovino Camargo Junior e à Márcia D’Aglio Foss (in memoriam), por terem compartilhado comigo suas inspiradoras reflexões sobre o papel da sensação na obra reichiana.

Aos participantes do Grupo de Aprofundamento em Teoria da Corporalidade - André Luiz Arouca, José Luís Schifferli Lopes, Marcia Walter Haro e Olinda Yoshiko Miura -, que acompanharam de perto, com acolhedor afeto, o gradual desenvolvimento desta pesquisa, dando sugestões fundamentais e não temendo embarcar nas mais insólitas viagens teóricas.

À Claudia Guzzardi Altieri e ao Guilherme Luz Fenerich, pela leitura atenta e instigantes comentários.

Ao Yevaldo Lemos Pereira, pela generosidade a todo o momento. 
À Paula Fábrio, pelas pertinentes dicas sobre a língua pátria.

À Joyce Romanelli, pelo incrível suporte logístico.

Ao meu filho, Icaro, pela "força" e torcida.

Aos meus pais, Lourdes e Luciano, pelo apoio contínuo. 
“A liberdade que às vezes sentia não vinha de reflexões nítidas, mas de um estado como feito de percepções por demais orgânicas para serem formuladas em pensamentos. Às vezes no fundo da sensação tremulava uma ideia que lhe dava leve consciência [...]."

(Clarice Lispector, 1943 - Perto do Coração Selvagem)

"Sou um guardador de rebanhos.

0 rebanho é os meus pensamentos

E os meus pensamentos são todos sensações.

Penso com os olhos e com os ouvidos

E com as mãos e os pés

E com o nariz e a boca.

Pensar uma flor é vê-la e cheirá-la

E comer um fruto é saber-lhe o sentido.

Por isso quando num dia de calor

Me sinto triste de gozá-lo tanto,

E me deito ao comprido na erva,

E fecho os olhos quentes,

Sinto todo o meu corpo deitado na realidade,

Sei a verdade e sou feliz"

[(Alberto Caeiro (Fernando Pessoa), 1925 - “O guardador de rebanhos”] 


\section{RESUMO}

BEDANI, A. A relação entre sensação e produção de conhecimento na obra de Wilhelm Reich. 2013. 212 f. Tese (Doutorado) - Instituto de Psicologia, Universidade de São Paulo, São Paulo, 2013.

Esta tese examina os estudos clínico-terapêuticos, laboratoriais e epistemológicos que Wilhelm Reich endereçou, no transcurso de sua obra, ao tema da sensação. Consultaram-se as seguintes fontes de dados: a) artigos, livros, correspondências, diários e transcrições de uma entrevista e de algumas conferências de Reich; b) trabalhos de comentadores da produção reichiana; c) textos de autores que marcaram significativamente as pesquisas de Reich sobre a apreensão sensorial, em particular, Friedrich A. Lange, Henri Bergson, Sigmund Freud e Richard Semon; d) estudos nos campos da História da Ciência e Filosofia da Ciência que permitiram resgatar linhas de investigação e posicionamentos epistemológicos que inspiraram as reflexões reichianas sobre a sensação. Procurou-se apontar quatro áreas de pesquisa que contribuíram para os estudos sensorialistas de Reich: as ciências biológicas e médicas (tais como a Protozoologia e Neurologia), o conhecimento psicológico (particularmente a Psicanálise), uma disciplina fundada pelo próprio autor (a Orgonomia) e a Teoria do Conhecimento (em especial, certa tradição neokantiana). Examinando-se as incursões de Reich por essas áreas, buscou-se identificar os estudiosos e correntes de pensamento que o estimularam em suas pesquisas sobre a dimensão sensorial e examinar as proposições estritamente reichianas - de teor clínico, experimental e epistemológico - a respeito da sensação. Observou-se que Reich partilhou da concepção de que uma sensorialidade básica se manifestaria em todos os seres vivos. Resgatou-se a tese reichiana de que níveis perceptivos elementares estariam diretamente associados, em organismos vivos, a uma singular força natural (a energia orgone), que o autor julgava ter descoberto e objetivado. Analisou-se a asserção de Reich de que, na produção humana de conhecimento, certas funções perceptivas rudimentares (filogeneticamente arcaicas) seriam continuamente modeladas pela estrutura de caráter (instância construída na relação dialética indivíduo-sociedade). Constatouse, por fim, que Reich, transitando por diferentes setores do saber e perseguindo rotas investigativas originais, procurou articular dois aspectos extremos do fenômeno sensorial: a sensação como propriedade básica da matéria viva e como ingrediente central da produção humana de conhecimento.

Palavras-chave: Reich, Wilhelm, 1897-1957. Sensação. Percepção. Epistemologia. 


\begin{abstract}
BEDANI, A. The relation between sensation and knowledge production in the work of Wilhelm Reich. 2013. 212 f. Tese (Doutorado) - Instituto de Psicologia, Universidade de São Paulo, São Paulo, 2013.
\end{abstract}

This thesis examines the laboratory, clinical therapeutic and epistemological studies that Wilhelm Reich, in the course of his work, dedicated to the subject of sensation. The following resources were consulted: a) articles, books, correspondences, diaries and transcriptions of an interview and of some of Reich's conferences; b) works of Reich's commentators; c) papers from authors that have significantly influenced Reich's research on sensorial apprehension, particularly Friedrich A. Lange, Henri Bergson, Sigmund Freud, and Richard Semon; d) studies in the fields of History of Science and Philosophy of Science that allowed the recovery of lines of investigation and epistemological positionings that have inspired the reichian reflexions on sensation. We tried to indicate four fields of research that have contributed to Reich's sensorial studies: the biological and medical sciences (such as the Protozoology and Neurology), the psychological knowledge (particularly the Psychoanalysis), a discipline created by the author himself (the Orgonomy), and the Theory of Knowledge (specially certain Neokantian tradition). Examining Reich's investigations on these fields, we tried to identify the scholars and currents of thought that have stimulated him in his research on the sensorial dimension and we tried to examine the strictly reichian propositions - of clinical, experimental and epistemological content - regarding sensation. It was observed that Reich shared the notion that a basic sensoriality would manifest in all living beings. We recovered the reichian thesis that elementary perceptive levels would be directly associated, in living organisms, to a singular natural force (the orgone energy), which the author believed to have discovered and objectified. We analyzed Reich's assertion that in human knowledge production, certain rudimentary perceptive functions (phylogenetically archaic) would be continuously modeled by the structure of character (a sphere built in the dialectic relationship individual-society). Finally, it was verified that Reich, transiting through different sectors of wisdom and chasing original investigative routes, tried to articulate two extreme aspects of the sensorial phenomenon: the sensation as a basic property of the living matter, and as a central ingredient of the human production of knowledge.

Keywords: Reich, Wilhelm, 1897-1957. Sensation. Perception. Epistemology. 


\section{SUMÁRIO}

1 INTRODUÇÃO

2 SENSAÇÃO E MOTILIDADE....................................... 19

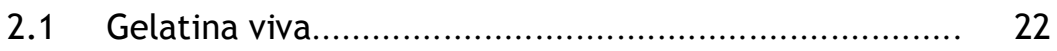

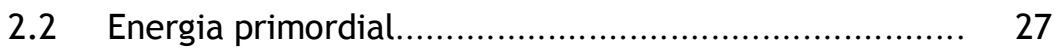

2.3 Função protoplasmática............................................ 52

2.4 Motilidade vegetativa............................................. 57

2.4.1 Crítica ao centralismo cerebral................................... 59

2.4.2 Anterioridade filogenética da função vegetativa........... 68

2.4.3 Vitalidade vegetativa e dimensão sócio-histórica........... 72

2.5 Couraça humana. ................................................ 74

2.5.1 Encouraçamento caracterial.................................... 75

2.5.2 Encouraçamento somático......................................... 80

2.6 Sensações de corrente............................................... 84

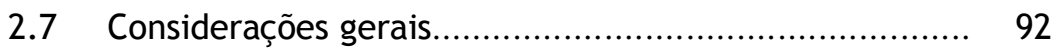

3 SENSAÇÃO E EXCITAÇÃO.......................................... 95

3.1 Psicologia como ciência natural................................. 97

3.1.1 Psicologia sem alma............................................... 98

3.1.2 Energia e psiquismo................................................ 104

3.1.3 Quantitativo e qualitativo........................................ 108

3.1.4 O terceiro fator...................................................... 113

3.1.5 Para além da psicologia.......................................... 116

3.2 Considerações gerais.................................................. 120

4 SENSAÇÃO E EMOÇÃO................................................ 124

4.1 Psicologia celular...................................................... 127

4.2 Emoção plasmática................................................... 135

4.3 Expressão emocional................................................ 139

4.4 As sensações de corrente no contexto terapêutico......... 142

4.5 Sensação, autopercepção e consciência........................ 145

4.6 Considerações gerais................................................ 152

5 SENSAÇĀO E CONHECIMENTO .................................... 155

5.1 Sensação plasmática e visão de mundo.......................... 157

5.1.1 Couraça e subjetividade............................................. 158

5.1.2 Organização psicofísica............................................. 164

5.1.3 Estrutura biopsíquica................................................ 172

5.2 Estrutura mecanicista e estrutura mística.................... 176

5.2.1 Encouraçamento e mecanicismo................................ 178

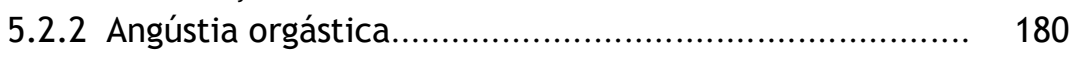

5.2.3 Encouraçamento e misticismo.................................... 183

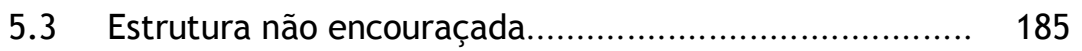

5.3.1 A função da empatia............................................... 187

5.4 Considerações gerais.................................................. 189

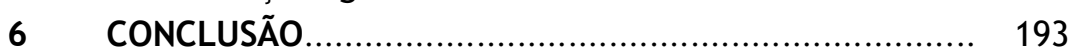

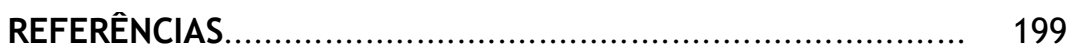




\section{INTRODUÇÃO}

"A sensação é o maior mistério da ciência natural." (W. Reich, 1949 - Ether, God and Devil). 
0 presente trabalho se propõe a examinar os estudos que o médico $\mathrm{e}$ cientista natural Wilhelm Reich (1897-1957) endereçou, no transcurso de sua obra, ao tema da sensação.

Bastante interessado, desde o início de sua produção, pelo problema da apreensão sensorial, Reich continuamente integrou a sensorialidade ao conjunto de suas pesquisas e fez dela um elemento-chave ao incursionar pelos terrenos clínicoterapêutico, laboratorial e epistemológico.

Ainda que o autor, ao longo de suas quase quatro décadas de trabalhos, tenha dedicado grande atenção ao fenômeno da sensação, não identificamos, na produção dos comentadores, análises aprofundadas sobre esse aspecto da pesquisa reichiana. Almejamos, aqui, dar alguma contribuição para minimizar essa lacuna.

Quatro áreas de estudos contribuíram significativamente, a nosso ver, para o entendimento de Reich sobre a sensação, e optamos por estruturar o presente texto de acordo com elas. Assim, examinamos, de forma sequencial, as influências que as asserções sensorialistas reichianas receberam: a) das ciências biológicas e médicas (tais como a Protozoologia e Neurologia); b) do conhecimento psicológico (particularmente, a Psicanálise); c) de uma disciplina fundada pelo próprio autor (a Orgonomia); d) da Teoria do Conhecimento (em especial, de certa tradição neokantiana).

Acompanhando o trajeto de Reich por tais setores, dedicamo-nos, sobretudo, a duas tarefas. Buscamos, sempre que possível, identificar os estudiosos e correntes de pensamento que o influenciaram em suas reflexões e pesquisas sobre a apreensão sensorial. E procuramos examinar as investigações estritamente 
reichianas - de teor clínico, experimental e epistemológico - a respeito do tema da sensação.

A conclusão geral a que chegamos, aqui, é a de que o autor, transitando por diferentes áreas do saber e perseguindo rotas investigativas próprias e originais, esforçou-se em estudar e articular dois aspectos extremos do fenômeno sensorial: a sensação como derivação de ancestrais matrizes fenomênicas do vivo e do cosmo e como ingrediente central da produção humana de conhecimento.

Ainda no que se refere ao escopo de nossa pesquisa, cumpre mencionar que não nos aventuramos a estabelecer quaisquer contrastes entre as proposições sensorialistas reichianas e outros referenciais teóricos ou estudos mais recentes acerca da sensação. Contrastes desse gênero são, sem dúvida, fundamentais e necessários, mas, dada a escassa pesquisa em relação ao tema da sensação na obra de Reich, optamos por dirigir nossos esforços, antes de tudo, no sentido de recuperar as conceituações formuladas pelo próprio autor e, na medida do possível, prospectar suas fontes históricas. Quando, contudo, nos deparamos com conceitos da Biologia ou Neurologia do século XIX e começo do século XX que não mantiveram, nos dias de hoje, seus significados originais, procuramos indicar (a título de breve contextualização e sem nos estendermos em análises críticas) a visão geral que se têm, atualmente, acerca de tais conceitos.

No que tange à pesquisa bibliográfica, consultamos, no campo da literatura reichiana, artigos, livros, correspondências e diários redigidos pelo autor ao longo de seu trajeto, além de uma entrevista concedida por ele e transcrições de algumas de suas conferências. Procuramos recorrer, também, aos comentadores do trabalho do cientista, embora ainda sejam raras, como mencionamos há pouco, as referências à temática em apreço. Consultamos ainda diversas obras, publicadas no 
século XIX e primeiras décadas do século XX, que permitiram resgatar matrizes da produção reichiana e valemo-nos de estudos nos campos da História da Ciência e Filosofia da Ciência.

O presente trabalho contém, além deste capítulo introdutório, cinco outros.

O segundo e próximo capítulo, "Sensação e motilidade", aborda certas contribuições da biologia e medicina para o entendimento reichiano acerca da sensorialidade. Nossas análises tomaram como ponto de partida, nesse capítulo, a filiação de Reich à tese de que a apreensão sensorial estaria diretamente associada a uma substância básica da matéria viva - o protoplasma - e far-se-ia presente mesmo em organismos que não apresentam sistema nervoso (tais como os seres unicelulares). Para compreender essa ampla sensorialidade plasmática, achamos por bem examinar, em um primeiro momento, o conceito de protoplasma na Biologia da segunda metade do século XIX e início do século XX. Julgamos necessário revisar brevemente, também, uma diretriz investigativa que permeou praticamente todo o trabalho de Reich: seus estudos sobre a energia, inclusive a energia orgone (uma 'força' natural que, de acordo com a visão reichiana, seria primária em relação à matéria). Após esses dois atalhos, examinamos a proposição do autor de que o protoplasma seria movido e se manteria vivo devido à ação daquela peculiar energia. Na sequência consideramos a tese reichiana de que haveria, em seres humanos, uma identidade entre o primitivo fenômeno da motilidade protoplasmática e a função vegetativa (função essa que unificaria toda massa plasmática do organismo humano). Nesse contexto pinçamos as críticas do autor à neurologia de sua época, a qual, apesar dos avanços no estudo do cérebro, estaria, a seu ver, desconsiderando a raiz filogenética do funcionamento plasmático-vegetativo. Acompanhamos, em seguida, os estudos de Reich a respeito 
de certo amortecimento ou encouraçamento, nas sociedades autoritárias, da função vegetativa e suas concomitantes pesquisas sobre um importante indicador da flexibilização desse encouraçamento: o fenômeno das correntes vegetativas (a livre movimentação do plasma no organismo). Pudemos identificar, então, um primeiro (e nuclear) elemento da teorização reichiana sobre a sensorialidade humana, posto que aquelas correntes ou fluxos se traduziriam, na visão de Reich, em um gênero específico e fundamental de apreensão sensorial (denominada por ele, de sensação plasmática, sensação vegetativa, sensação orgonótica ou sensação de órgão). Por se tratar de aspecto central no entendimento do autor sobre a dimensão sensorial e por ter suscitado, ao longo da obra reichiana, investigações clínicas, experimentais e epistemológicas, o conceito de sensação plasmática continuará sendo analisado a partir de diferentes ângulos, nos próximos capítulos deste trabalho.

No terceiro capítulo, "Sensação e excitação", examinamos as influências de certo conhecimento psicológico nas proposições sensorialistas reichianas. Para tanto, retomamos o interesse do autor por uma psicologia científico-natural, algumas de suas aproximações com o freudismo e as críticas que dirigiu à psicologia wundtiana. Averiguando inicialmente o posicionamento reichiano de que as investigações experimentais de Wundt acerca da sensação e percepção não confeririam cientificidade à pesquisa em psicologia, resgatamos, na sequência, a simpatia de Reich, no primeiro estágio de sua produção, pelos referenciais energéticos freudianos. Analisamos então como essas críticas à abordagem experimental e o contato com a teoria psicanalítica contribuíram para uma crucial diretriz de pesquisa reichiana: a tentativa de ampliar o entendimento acerca da relação entre sensação psicológica de prazer e impulso sexual somático e de 
encontrar, também, a matriz ou denominador comum desses dois fenômenos. Nesse contexto pudemos observar a forte influência, não apenas de Freud, mas de autores como Lange, Bergson e Semon no projeto reichiano de vincular, de um ângulo científico-natural, o âmbito sensório-qualitativo (a partir da percepção prazerosa) e o âmbito energético-quantitativo (a partir da excitação corporal). E constatamos que a busca de Reich por um denominador comum entre sensação e excitação determinou sua trajetória científica e apontou, uma vez mais, para a questão da motilidade plasmático-vegetativa.

O quarto capítulo, "Sensação e emoção", analisa a teorização estritamente reichiana acerca da apreensão sensorial. Como ponto de partida, resgatamos uma vez mais a tese de Reich de que as reações de prazer e angústia estariam enraizadas no automovimento protoplasmático, mesmo em micro-organismos. Procuramos demonstrar, então, que essa proposição reichiana se inspirou em uma perspectiva investigativa conhecida como psicologia celular, perspectiva essa que vislumbrou a existência, em seres unicelulares, de rudimentos do psiquismo humano. Retornando à pesquisa do autor, pudemos notar que ele, amparando-se em seus estudos clínicos e laboratoriais, não apenas atribuiu o movimento plasmático à ação de uma força específica e concreta (a energia orgone, a seu ver), como também, concebeu tal motilidade espontânea como fator unificador no campo do vivo. Observamos então que Reich se esforçou em demonstrar que o automovimento plasmático estaria na base da sensorialidade humana e, até mesmo, das complexas funções psicológicas. Verificamos ainda, nesse âmbito, que o autor atribuiu um novo sentido ao termo emoção, alargando consideravelmente seu escopo: a emoção como movimento plasmático espontâneo, em toda e qualquer criatura vivente. E averiguamos como ele articulou aquela emoção 
plasmática, não apenas ao tema da sensorialidade, mas também ao fenômeno da autopercepção e à instância da consciência.

O quinto capítulo, "Sensação e conhecimento", examina como as proposições sensorialistas reichianas se inserem em certa tradição neokantiana a respeito da construção do conhecimento. Para iniciar esse capítulo, pautamo-nos por um duplo movimento sugerido pelo autor: a sensação plasmática determinando a produção de conhecimento e, ao mesmo tempo, sendo determinada pela estrutura biopsíquica do sujeito. Focando a primeira parte dessa formulação dialética, retomamos o argumento reichiano de que a sensorialidade plasmática seria um ingrediente fundamental e, até mesmo, a base para a construção do pensamento lógico. Voltando-nos ao outro lado da moeda, averiguamos a asserção do autor de que haveria uma arraigada instância - por ele denominada, entre outras expressões, de estrutura biopsíquica - que valoraria e regularia o contato do indivíduo com suas próprias sensações plasmáticas. Nesse momento consideramos cabível retomar certas origens filosóficas desse conceito de estrutura biopsíquica, tarefa que nos fez encontrar, uma vez mais, certas ideias de Lange, especialmente seu projeto de atualizar a teoria kantiana do conhecimento por meio da noção de organização psicofisiológica. Após nos familiarizarmos com essa visão langeana acerca da modulação da subjetividade, passamos à teoria de Reich de que haveria, nas sociedades autoritárias, dois grandes grupos de estruturações ou formatações biopsicológicas: a estrutura mecanicista e a estrutura mística, segundo a terminologia proposta pelo autor. Nesse contexto, analisamos o ponto de vista reichiano de que ambas as estruturas teriam sofrido profundas disfunções em suas correntes e sensações plasmáticas e a sua tese de que haveria, na estrutura não encouraçada, uma promissora retroalimentação entre sensorialidade e visão de 
mundo afirmativa. E nos debruçamos, por fim, em duas importantes formulações do autor: a de que existiria um grande número de pesquisadores afetados por crônico amortecimento da vitalidade vegetativa e a de que tais pesquisadores, por bloquearem ou distorcerem suas sensações plasmáticas, poderiam colorizar a investigação científica com elementos mecanicistas ou espiritualistas.

No sexto e último capítulo, “Conclusão", tecemos algumas apreciações gerais sobre a pesquisa sensorialista reichiana e os limites do presente estudo. 


\section{SENSAÇÃO E MOTILIDADE}

"A percepção faz-se presente desde as primeiras expansões e contrações plasmáticas."

(W. Reich, 1944 - Orgonotic Pulsation. Part One). 
Para começarmos a averiguar a questão da sensorialidade na obra reichiana, retomaremos algumas proposições gerais sobre o fenômeno, apresentadas pelo autor em Ether, God and Devil (“Éter, Deus e o Diabo"), um escrito de teor epistemológico publicado em 1949. Na obra em apreço o pesquisador caracterizou a apreensão sensorial como um fenômeno de suma importância, não apenas para a existência humana, mas também para o funcionamento dos seres vivos em geral: "O organismo vivo percebe o entorno e a si mesmo tão somente por meio de suas sensações" (REICH, 1949/1973c, p. 56, tradução nossa, grifo do autor). A sensação, quando abordada "funcionalmente", expressaria "uma cuidadosa sondagem (feeling out) da realidade", um contínuo rastreamento dos estímulos "internos e externos”. Essa perscrutação sensorial poderia ser facilmente visualizada, segundo o autor, nos movimentos "lentos, tateantes e ondulares" das "antenas ou tentáculos” (p. 96, tradução nossa) de certos animais.

Ponderando sobre as matrizes biológicas do fenômeno sensorial, Reich partilhou da polêmica tese de que a sensorialidade manifestar-se-ia até mesmo em criaturas que não apresentam sistema nervoso: "Toda matéria plasmática percebe, com ou sem nervos sensoriais". Um micro-organismo como a ameba seria dotado, realçou o autor, de algum nível de apreensão sensorial, apesar de não dispor de "quaisquer nervos sensoriais ou motores" (REICH, 1949/1973c, p. 117-118, tradução nossa). O "protoplasma” desse unicelular apresentaria, até mesmo, “funções de expansão prazerosa e contração angustiosa” (p. 111, tradução nossa).

É possível identificar diversas outras menções, na produção reichiana, ao protoplasma e a sua sensorialidade, anteriores inclusive à publicação de Ether, God 
and Devil. Em 1934, o autor já havia expressado a opinião de que "os aparatos da função sexual e da função de angústia” (REICH, 1934/1982a, p. 38, tradução nossa) estariam presentes em criaturas unicelulares. Ao se amparar, a partir de 1935, em seus próprios experimentos microbiológicos, ${ }^{1}$ o cientista continuou designando como prazerosos e angustiantes determinados movimentos de expansão e retração observados por ele mesmo (e por pesquisadores que lhe foram contemporâneos) no protoplasma de alguns organismos unicelulares (REICH, 1938/1979). ${ }^{2}$

$\mathrm{Na}$ visão reichiana haveria, portanto, íntima conexão entre certas sensações (especialmente, de prazer e angústia) e a plasticidade do protoplasma (particularmente, os movimentos de contração e expansão), mesmo em organismos que não apresentam sistema nervoso. Indo mais longe, o autor, pautando-se por suas pesquisas teóricas e experimentais, chegou a afirmar que a própria vida tomaria raízes na “contração plasmática” (REICH, 1948/2007, p. 36, tradução nossa).

Antes de nos aprofundarmos nessas proposições sensorialistas reichianas, cabe compreender melhor um de seus principais elementos: o conceito de protoplasma. Desempenhando importante papel na obra de Reich e no trabalho de diversos pesquisadores que o antecederam ou the foram contemporâneos, a substância protoplasmática, como notaremos logo abaixo, estaria associada não apenas à perscrutação sensorial, mas também às funções motrizes e à dinâmica geral da própria vida.

\footnotetext{
${ }^{1}$ Retomaremos brevemente esses experimentos, mais adiante.

${ }^{2}$ Como veremos em detalhes no quarto capítulo do presente estudo, a ideia de que haveria algum nível de apreensão sensorial em organismos unicelulares não é nativa da produção de Reich, tendo sido explorada por diversos pesquisadores que o antecederam, alguns deles, adeptos da tese de que os microorganismos carregariam rudimentos não apenas da fisiologia, mas também do psiquismo humano.
} 


\subsection{Gelatina viva}

Uma das "mais significativas" (WELCH; CLEGG, 2010, tradução nossa) proposições da História da Biologia, o conceito de protoplasma despontou na primeira metade do século XIX e despertou grande interesse nas ciências biológicas até as décadas iniciais do século XX (CORREA, 1998; GEISON, 1969). Para os cientistas do período, o protoplasma designava, em linhas gerais, um composto gelatinoso, contráctil e irritável que, fazendo-se presente nas cavidades dos organismos unicelulares e das células dos multicelulares, estaria diretamente associado às propriedades essenciais da vida.

Em 1835, o biólogo francês Félix Dujardin (1802-1860) propôs o termo sarcode - que não tardaria a evoluir para protoplasma (TIXIER-VIDAL, 2010) - com o intuito de designar a substância viscosa, elástica, homogênea, transparente e contrátil que ele identificara no interior dos rizópodes. ${ }^{3}$ Em trabalho publicado em 1838, o biólogo afirmou que o sarcode dos "animais superiores" poderia revelar “um grau de organização mais complexo" (na forma, por exemplo, de fibras ou membranas), mas que nos "animais localizados na base da escala" nada mais se visualizaria do que uma "gelatina viva, contrátil” (DUJARDIN, 1838, p. 256-257, tradução nossa).

A partir de tais pesquisas começou a se formar, como veremos a seguir, a ideia de que as propriedades vitais de todo ser vivo dependeriam diretamente da presença, em suas células, de "substâncias fluídas" (HALL, 1950, p. 339, tradução nossa), tais como as que Dujardin descreveu. Veremos também que o grau de

\footnotetext{
${ }^{3}$ Rizópodes: categoria de unicelulares - a qual pertence a ameba - que fazem uso de pseudópodos para se locomover e obter alimentos.
} 
organização ou estruturação dessa substância tornou-se um tema relevante para diversos pesquisadores, inclusive Reich.

Em 1840, o fisiologista checo Johannes E. Purkinje (1787-1869) empregou pela primeira vez o termo protoplasma para designar certos grânulos esféricos e gelatinosos que comporiam o embrião animal (HUGHES, 1959; CORREA, 1998). 0 botânico alemão Hugo von Mohl (1805-1872) utilizou o mesmo vocábulo em 1846, referindo-se à presença de protoplasma nas células das plantas (GEISON, 1969). Não tardou para que Ferdinand Cohn (1828-1898), outro botânico alemão, visse uma identidade entre o protoplasma das plantas e dos animais (HALL, 1950), propondo em seus estudos que as cavidades de todos os tipos de células seriam preenchidas por “substância contrátil” (COHN, 1850, citado em GEISON, 1969, p. 275, tradução nossa). A própria célula chegou a ser vista, na época, como mero alojamento para o protoplasma (WELCH; CLEGG, 2010).

Amparado por pesquisas empreendidas no período 1858-1861, o anatomista alemão Max Schultze (1825-1874) chamou atenção para certas propriedades que seriam inerentes ao protoplasma - como a contratilidade (movimento espontâneo) e a irritabilidade (capacidade de responder aos estímulos) -, concebendo-o como "substrato da atividade vital dos tecidos de todos os organismos, fossem tais organismos simples ou complexos". Com os estudos de Schultze, o termo protoplasma, como indica um comentador, passou a ser amplamente adotado para designar "a substância viva de animais e plantas” (GEISON, 1969, p. 276-277, tradução nossa).

Na segunda metade do século XIX disseminou-se rapidamente a concepção de que as condições essenciais da vida residiriam "em uma substância chamada protoplasma” (GEISON, 1969, p. 278, tradução nossa), substância essa que 
simbolizaria a "funcionalidade da vida em seu nível mais básico" (WELCH; CLEGG, 2010, tradução nossa). Na década de 1860, por exemplo, o protoplasma era frequentemente definido como uma massa viscosa e transparente de caráter homogêneo, "sem estrutura” e "sem organização visível” (M’KENDRICK, 1888, citado em WELCH; CLEGG, 2010).

Matéria viva par excellence, o protoplasma seria dotado, antes de tudo, de contratilidade, como salientou em 1878 o médico e fisiologista Claude Bernard (1813-1878). Para o eminente cientista, a propriedade contráctil estaria presente na "maior parte das massas protoplasmáticas animais ou vegetais" (BERNARD, 1879, p. 224, tradução nossa), daria sustentação a todo e qualquer movimento dos seres vivos e seria regulada exclusivamente por determinações físico-químicas internas e externas, não por forças vitais especiais.

Além da contratilidade (e da irritabilidade), outras características foram atribuídas à substância protoplasmática no decorrer do século XIX, tais como digestão (assimilação de nutrientes), respiração e reprodução (WELCH; CLEGG, 2010). Tamanha seria a importância do protoplasma, que o biólogo inglês Thomas H. Huxley (1825-1895) se referiu a ele, em conferência proferida em 1868, como a “'base física da vida”” (HUXLEY, 1870, p. 7, tradução nossa). Em sua opinião, as investigações sobre o protoplasma deveriam se assentar na mais estrita abordagem físico-química - ou seja, "na natureza e disposição das moléculas” (p. 26, tradução nossa) -, não em um entendimento da vida como algo que atuaria "por meio da matéria”, mas seria “independente dela” (p. 7, tradução nossa).

Certo grupo de pesquisadores vitalistas julgou, porém, que a noção de protoplasma teria potencial para "explodir a concepção mecanicista de vida" 
(GEISON, 1969, p. 284, tradução nossa). ${ }^{4}$ O médico e microscopista inglês Lionel S. Beale (1828-1906), por exemplo, recusou-se a reduzir o funcionamento protoplasmático (e o próprio fenômeno da vida) exclusivamente a fatores físicoquímicos; em obra publicada em 1870, ele afirmou que não haveria nada na matéria viva que se assemelhasse a um "mecanismo". No protoplasma, "pequeníssimo material transparente e incolor", estariam contidas "impressionantes forças ou propriedades" responsáveis pela "forma, função e estrutura" dos seres vivos. Essas impressionantes propriedades ou potências não teriam quaisquer semelhanças com as forças físicas conhecidas e encontrariam tradução na forma de três fenômenos vitais: "crescimento, movimento espontâneo e organização (formation)" (BEALE, 1870, p. 32, tradução nossa). A capacidade de movimento representaria, aliás, um dos mais importantes "atributos da matéria viva” (p. 75, tradução nossa) e a criatura vivente seria inimaginável sem essa característica. Dos "menores organismos dotados das mais básicas características” às "texturas dos seres mais complexos" seria possível identificar, no entendimento do microscopista, dois estados básicos que, inclusive, definiriam o ser vivo de forma mais adequada do que a noção de protoplasma: a "matéria viva ou germinativa" e a "matéria estruturada (formed)" (p. 32, tradução nossa). Expressando com clareza a ação de uma força vital, a parcela do organismo concernente à "matéria viva ou germinativa" seria responsável pelas funções de

\footnotetext{
${ }^{4}$ Ora apoiando-se em perspectivas teológicas, ora circulando pelo campo da filosofia, ora procurando calcar-se na experimentação científica, surgiram, entre o século XVIII e o início do século XX, diversas proposições de índole vitalista. De forma geral, os vitalistas questionavam enfaticamente a aplicação, ao estudo da vida, de conceitos e métodos originários das ciências do inorgânico. Privilegiando perspectivas mais holísticas ou sistêmicas do que pontuais ou atomistas, eles procuraram analisar as relações - ou oposições - que se estabeleceriam entre o fenômeno 'vida' e os processos mecânicos e físico-químicos. Também foi comum, às diversas formas de vitalismo, a crença de que os organismos vivos seriam regidos por um fator intrínseco especial (força vital, potência prospectiva, entre outros) que fugiria ao alcance da análise mecanicista (BEDANI, 2007a).
} 
movimento espontâneo, crescimento e multiplicação. A “matéria estruturada (formed)", por sua vez, diria respeito à porção do corpo que, embora tivesse apresentado em algum momento a propriedade de desenvolvimento espontâneo, teria se tornado posteriormente inerte e incapaz de se multiplicar por si mesma. Nas amebas - “massas animadas" de "matéria movente transparente" - poder-seia observar com facilidade a propriedade do "automovimento" (p. 37, tradução nossa). A “fibra nervosa" humana seria, por sua vez, um exemplo de "matéria estruturada (formed)" (p. 53, tradução nossa).

Procurando compreender o protoplasma a partir de referenciais estritamente físico-químicos ou tentando identificar nele a ação de uma singular força vital irredutível às leis da mecânica (ou ainda, tentando conciliar de alguma forma as duas perspectivas), diversos biólogos do século XIX e início do século XX partilharam da ideia, em suma, de que existiria - em plantas e animais, em unicelulares e multicelulares - uma substância contráctil-irritável elementar. ${ }^{5}$

Herdeiro confesso de certas realizações “científicas e humanistas do século XIX e início do século XX” (REICH, 1949/1973c, p. 8, tradução nossa), Reich sofreu forte influência da teoria protoplasmática e valeu-se dela para formular seu entendimento a respeito da apreensão sensorial. Mas, ainda que tenha se inspirado

\footnotetext{
${ }^{5}$ Sem qualquer propósito de examinarmos o impacto e implicações da teoria protoplasmática na biologia atual, cabe mencionar en passant que o biólogo, naturalista e historiador da ciência Ernst W. Mayr (19042005) esclareceu que o protoplasma, "o material celular fora do núcleo", é atualmente designado como citoplasma. Mayr comentou, ainda, que a teoria protoplasmática caiu em desuso na literatura biológica, pois a bioquímica e a microscopia eletrônica do século XX teriam estabelecido "a verdadeira composição do citoplasma" e elucidado "a verdadeira natureza de seus vários componentes: organelas celulares, membranas e macromoléculas" (MAYR, 2008, p. 34-35). Em trabalho publicado recentemente, dois outros comentadores chamaram atenção, por sua vez, para o fato de que a teoria protoplasmática, por conceber a célula como "um todo dinâmico", desempenhou importante papel na história da Biologia, pavimentando o caminho para o estudo de "tudo o que, agora, associamos com a estrutura e função celular" e para o atual entendimento da célula como um sistema. Resíduos do conceito de protoplasma reapareceriam, na atualidade, em estudos que abordam a célula viva a partir de uma perspectiva dinâmica, funcional e "holística" (WELCH; CLEGG, 2010, tradução nossa). Foi essa perspectiva dinamista que, sem dúvida, cativou Reich e o influenciou significativamente em suas ponderações sobre o protoplasma, como veremos a seguir.
} 
na concepção protoplasmática, ele a reexaminou de uma singular perspectiva energética - perspectiva essa que permeou, aliás, toda sua produção.

Como a sensorialidade, para Reich, tomaria raízes em um protoplasma energeticamente excitado, precisaremos tomar um atalho e examinar, ainda que panoramicamente, a que energia se referia o autor. Após essa breve retomada dos estudos reichianos sobre a energia, estaremos mais instrumentalizados para compreender como o cientista, partindo de uma interpretação energética do protoplasma, construiu suas próprias teorias sensorialistas.

\subsection{Energia primordial}

Não apenas as formulações de Reich a respeito do protoplasma e da apreensão sensorial, mas praticamente todos os estudos que empreendeu ao longo de sua carreira - fossem eles de índole científica, laboratorial, sociológica ou epistemológica - receberam fortes colorações energéticas. Contudo, não nos aprofundaremos, aqui, nos diversos questionamentos que a pesquisa energética reichiana certamente suscita. A fim de não nos distanciarmos excessivamente de nossas investigações, vamos nos limitar a descrever as proposições do autor, a respeito da energia, que nos pareçam fundamentais para o entendimento do tópico da sensação.

O próprio Reich, que acreditava que seu trabalho se inseria no campo da ciência natural, realçou, aos 53 anos de idade, o papel determinante da dimensão energética em sua obra. Em uma palestra proferida em 26 de agosto de 1950, ele deixou claro que sua preocupação com o tema da energia remontava à fase inicial de seu trabalho: 
Sou antes de tudo um cientista natural, não um psicólogo e, claro, não um psicanalista. Dediquei-me a todo o campo da psiquiatria como cientista natural. Esse interesse foi ditado, em primeiro lugar, pela questão da energia. Já era assim em 1919 (REICH, 1990b, p. 50, tradução nossa).

Em 1919, Reich estava iniciando o curso de medicina na Universidade de Viena (a formatura ocorreu em 1922) e aproximando-se da psicanálise (em outubro de 1920 ele foi aceito como membro da Associação Psicanalítica de Viena, antes mesmo de terminar a graduação universitária) (REICH, 1942/1989). Foi também por volta de 1919-20 que o autor formulou a hipótese que direcionou toda a sua obra, ao conjecturar que os fenômenos naturais estariam assentados, em derradeira instância, em um peculiar processo energético. Na base dos eventos naturais deveria agir, cogitou o jovem Reich, uma energia primária ou primordial, anterior à matéria. Uma energia que seria, em si, livre de massa, mas que, de alguma maneira, poderia gerar unidades materiais (REICH, 1950/1990d).

Quando contava com aproximadamente 50 anos de idade, o autor relembrou que sua "antiga suposição de 1920" continha três aspectos: a) "que a energia funciona ANTES de qualquer massa”; b) “que não é a matéria, mas sim a energia que é primária"; c) "que a massa precisa ser derivada, de alguma forma, da energia” (REICH, 1996a, p. 13, tradução nossa, grifo do autor). ${ }^{6}$

\footnotetext{
${ }^{6}$ Veremos mais à frente que o autor, em determinado momento de sua produção, julgou ter objetivado laboratorialmente essa energia pré-massa ou primária. No que tange especificamente às especulações do jovem Reich a respeito de uma energia primordial anterior à matéria, cabe mencionar que elas dificilmente se coadunariam, como demonstramos em outro trabalho (BEDANI, 2007a), com os rumos teóricos e experimentais que a Física vinha adotando no final do século XIX e início do século XX. A ideia de uma energia fundante que antecede a matéria (ou à equivalência massa-energia) certamente soaria, ao meio científico, como uma visão metafísica da natureza. Além disso, a Física vinha evitando caracterizar a energia como uma coisa ou substância, procurando muito mais mensurá-la e quantificá-la do que especular sobre sua essência, ao passo que Reich, ao se referir a uma energia primária, tinha em mente uma entidade física concreta ou um fenômeno natural cujas propriedades poderiam ser observadas laboratorialmente, e não apenas uma relação de equivalência numérica.
} 
O Reich estudante de medicina e psicanalista não se limitou, porém, a conjecturar a respeito de um processo energético primário que se manifestaria na natureza inorgânica e que, por suas características fenomênicas, não se acomodaria às determinações mecano-materialistas; ele também mostrou simpatia pelo conceito de energia biológica específica, energia essa que seria praticamente idêntica ou, ao menos, estaria diretamente associada ao fenômeno da vida (REICH, 1942/1989). Frequentemente sugerida pelos filósofos e cientistas vitalistas, essa singular energia não se assemelharia, no entendimento daqueles estudiosos, às formas de energia investigadas pela Física e apresentaria uma dinâmica inacessível à lógica mecanicista.

Entre os autores que defendiam a existência de uma energia corporal específica estava o biólogo austríaco Paul Kammerer (1880-1926), professor de Reich na Universidade de Viena e influência teórica marcante na produção reichiana (BEDANI, 2007a). Um trecho da obra Allgemeine Biologie, publicada por Kammerer em 1915, retrata com nitidez a diretriz teórica que encantou o jovem Reich e, como veremos mais à frente, determinou sua obra:

Se, transgredindo os limites do aceitável, eu precisasse finalmente afirmar o que julgo ser o mais provável - uma crença científica não comprovada e, até o momento, não passível de comprovação -, teria então que dizer: a existência de uma força vital específica parece-me inteiramente plausível! Uma energia que não é calor, eletricidade, magnetismo, energia cinética (inclusive oscilação e radiação), nem energia química, nem um amálgama de algumas ou todas essas energias, mas uma energia que pertence especificamente àqueles processos naturais que chamamos 'vida'. 0 que não significa que sua presença se restrinja àqueles corpos naturais que denominamos de 'seres vivos', mas que ela também se faz presente, pelo menos, no processo de formação dos cristais. Por isso, uma designação mais adequada para ela, a fim de se evitar mal-entendidos, poderia ser 'energia formadora' ao invés de 'energia vital'. Essa 'energia 
formadora' não apresenta qualquer propriedade suprafísica, embora nada tenha em comum com as energias físicas conhecidas até o momento. Não seria uma misteriosa 'enteléquia' (Aristóteles, Driesch), mas sim, uma 'energia' natural autêntica, associada aos fenômenos da vida, criação e modificação de formas, assim como a energia elétrica está associada aos fenômenos elétricos e a energia química às transformações químicas. Acima de tudo, estaria sujeita à lei da conservação de energia e, sob certas circunstâncias, poderia se converter em outras formas de energia, da mesma forma que, por exemplo, o calor pode ser convertido em energia cinética e vice-versa (KAMMERER, 1915, citado em REICH, 1948/1973e, p. 9, tradução nossa). ${ }^{7}$

Reich, que tinha como centro de suas preocupações, desde o início da década de 1920, a complexa e intrigante questão “O que é a vida?” (REICH, 1942/1989, p. 22, tradução nossa), via certo sentido nas proposições vitalistas acerca de uma energia biológica específica ou força criadora, mas se incomodava profundamente com o fato de tais proposições jamais alcançarem sólida comprovação experimental e serem, por isso, frequentemente tachadas de especulação metafísica ou espiritualista. Por se opor a "qualquer concepção metafísica acerca da natureza” (REICH, 1950/1990d, p. 4, tradução nossa), ele acreditava que apenas a ciência natural teria, eventualmente, condições de validar as proposições energéticas vitalistas:

A ideia de uma força criadora que governa a vida parecia irrefutável. Contudo, ela não ganharia aceitação enquanto não se tornasse tangível, descritível e manejável concretamente. A aplicabilidade prática era considerada, com razão, o objetivo supremo da ciência natural (REICH, 1942/1989, p. 24, tradução nossa).

0 interesse de Reich pela questão energética permeou, também, sua

\footnotetext{
${ }^{7}$ Cabe lembrar, ainda, que certa perspectiva vitalista também se fez presente no trabalho de dois outros autores que marcaram a produção reichiana: o filósofo francês Henri Bergson (1859-1941) e o biólogo e filósofo alemão Hans Driesch (1867-1941) (BEDANI, 2007a).
} 
participação no movimento psicanalítico entre 1920 e 1934. Na opinião do autor, conceitos freudianos como libido e impulso (Trieb), ainda que carecessem de objetivação laboratorial, poderiam estabelecer alguma interface entre a psicanálise e a ciência natural. Em diversas oportunidades, ele reconheceu que a noção psicanalítica de energia sexual foi fundamental na primeira etapa de sua produção, contribuindo para suas pesquisas sexológicas, clínicas e sociológicas. Esse reconhecimento pode ser observado, por exemplo, em uma entrevista que o pesquisador concedeu em 1952 ao The Sigmund Freud Archives. Reich então esclareceu que havia simpatizado com a teoria da libido não por se sentir “especialmente partidário do sexo no sentido usual do termo", mas sim, porque tal teoria expressaria "um princípio científico natural concernente à quantidade de energia e ao funcionamento objetivo" (HIGGINS; RAPHAEL, 1972, p. 122, tradução nossa). Partindo do pressuposto de que a ciência natural não poderia prescindir da referência energética, ele era da opinião que, com a teoria da libido a psicologia teria se vinculado à ciência natural "pela primeira vez na história da ciência" ( $\mathrm{p}$. 126 , tradução nossa, grifo do autor). ${ }^{8}$

A teoria da potência orgástica, gradualmente elaborada pelo autor no período 1922-1926 e um dos pilares de sua obra, é um exemplo de pesquisa reichiana que recebeu forte influência da noção de libido. Trabalhando, no estágio inicial de sua produção, como médico-psicanalista em Viena, Reich pautou suas primeiras investigações clínicas pela ideia de que haveria uma fonte de energia alimentando continuamente as perturbações psíquicas. Em 1923, defendeu a tese de que essa fonte ou núcleo da neurose residiria em uma estase (estagnação ou

\footnotetext{
${ }^{8}$ No próximo capítulo retomaremos o interesse reichiano pelos referenciais energetistas freudianos.
} 
acúmulo) da excitação sexual, estase essa que, a seu ver, seria predominantemente gerada por uma insatisfatória descarga genital da libido. Impossibilitada de escoar genitalmente, a excitação acabaria tomando rotas prégenitais, as quais, ainda que trouxessem algum alívio momentâneo, intensificariam em última instância o complexo e desgastante quadro neurótico. A experiência clínica teria demonstrado a Reich, contudo, que a recuperação da "função genital" (REICH, 1942/1989, p. 110, tradução nossa) poderia propiciar o desaparecimento ou a significativa diminuição dos sintomas neuróticos. Pois, para o autor, o aparelho genital seria o mecanismo mais eficaz para a descarga das tensões sexuais acumuladas.

Em 1924, durante um congresso psicanalítico, e no ano seguinte por meio de um artigo - "Weitere Bemerkungen ueber die therapeutische Bedeutung der Genitallibido" (Observações complementares sobre o significado terapêutico da libido genital $)^{9}-$, o jovem pesquisador lançou o conceito de potência orgástica, considerando-o crucial para a resolução das “perturbações neuróticas da libido" (REICH, 1925/1975a, p. 210, tradução nossa) e ousando ainda afirmar que nenhuma análise poderia ser considerada como terminada enquanto a "potência orgástica genital” (p. 214, tradução nossa) não estivesse assegurada.

Após ter atendido um expressivo número de pacientes, fundamentou ainda mais suas formulações em obra escrita em 1926 e publicada no ano seguinte, Die Funktion des Orgasmus (“A função do orgasmo”). ${ }^{10}$ A potência orgástica foi então

\footnotetext{
9 Consultamos aqui uma tradução desse artigo para a língua inglesa - "Further remarks on the therapeutic significance of genital libido" (REICH, 1925/1975a).

${ }^{10}$ A obra Die Funktion des Orgasmus, que veio a público em Viena no ano de 1927, não deve ser confundida com a autobiografia científica de Reich, The function of the orgasm, publicada nos EUA em 1942; essa autobiografia faz referências à obra de 1927, mas vai além, pois abarca duas décadas de pesquisas reichianas. Recorremos aqui a duas versões norte-americanas de Die Funktion des Orgasmus:
} 
definida "fenomenologicamente" como a "aptidão" de a personalidade imergir plenamente na "experiência genital", "apesar de eventuais conflitos pessoais" (REICH, 1927/1980b, p.15, tradução nossa).

A capacidade psíquica de experienciar "a plena entrega genital" (REICH, 1942/1989, p. 175, tradução nossa) seria inseparável da dimensão bioenergética da experiência orgástica, como esclareceu o autor em sua autobiografia científica:

Potência orgástica é a capacidade de se entregar ao fluxo da energia biológica, sem quaisquer inibições; a capacidade de descarregar completamente, por meio de convulsões involuntárias e prazerosas do corpo, a excitação sexual acumulada (REICH, 1942/1989, p. 102 tradução nossa). ${ }^{11}$

Opondo-se, desde o início de seu trabalho, às teorias sexológicas de sua época que consideravam as potências eretiva e ejaculatória, assim como a sensibilidade e lubrificação vaginais, como critérios suficientes para uma relação sexual satisfatória (REICH, 1925/1975a, 1927/1980b), o autor, fundamentando-se em ampla pesquisa clínica, procurou demonstrar que algo mais precisaria se associar àqueles fenômenos para que o indivíduo experienciasse um profundo alívio da tensão sexual. Esse algo se manifestaria certamente, a seu ver, em indivíduos “orgasticamente potentes” (REICH, 1942/1989, p. 105, tradução nossa), ou seja,

Genitality - In the theory and therapy of neurosis (REICH, 1927/1980a), que não reproduz exatamente o livro original, posto que o autor, ao revisar a obra na década de 1940, introduziu significativas alterações no texto; e The function of the orgasm (REICH, 1927/1980b), uma tradução feita diretamente do original.

11 A teoria freudiana da libido contribuiu para diversas outras formulações do primeiro estágio do trabalho de Reich, sobre as quais não discorreremos aqui, posto que pretendemos retomar, das pesquisas reichianas sobre os processos energéticos, tão somente os aspectos necessários para avançar no entendimento do tema da sensação. Cabe registrar, no entanto, que o ponto de vista econômico freudiano marcou forte presença nos primeiros estudos de Reich sobre a teoria da técnica terapêutica consubstancializados no livro Charakteranalyse (“Análise do caráter”) (REICH, 1933/1969) - e em suas produções freudo-marxistas, como se pode observar, por exemplo, na obra Massenpsychologie des Faschismus ("Psicologia de massas do fascismo") (REICH, 1933). 
em indivíduos em que a "função genital” (p. 110, tradução nossa) teria a capacidade de concentrar a excitação sexual proveniente do corpo e desencadear, em seguida, convulsões orgásticas involuntárias. Essas convulsividades de natureza orgástica seriam indissociáveis de um concomitante sentimento de entrega e substancializariam, na visão reichiana, a experiência sexual satisfatória, com plena descarga da excitação acumulada.

A maior parte da humanidade, no entanto, padeceria, segundo o cientista, de impotência orgástica, condição patológica que, por carecer daquele algo, abarcaria desde a completa apatia erótica (com eventuais sintomas de impotência eretiva ou insensibilidade vaginal) até as relações sexuais em que a diminuta satisfação (ou mesmo a plena insatisfação) seriam a regra (REICH, 1942/1989).

Fiel à sua perspectiva científico-natural, o autor se propôs a investigar laboratorialmente aquele 'algo mais' (o fator que precisaria se associar ao âmbito fisiológico para propiciar a experiência da potência orgástica), em um período em que sua vida e obra se entrelaçavam com dramáticos acontecimentos históricos. Morando em Berlim quando Hitler chegou ao poder, Reich, crítico ferrenho do nacional-socialismo, precisou deixar a Alemanha por conta da perseguição nazista. Expulso em 1933 do Partido Comunista Alemão (realizando, desde 1927, estudos de cunho freudo-marxista e desenvolvendo, junto às organizações de esquerda, projetos sociais de orientação sobre sexualidade, ele foi acusado pelos burocratas do partido de dar mais atenção à política sexual do que à política econômica), Reich também deixou de ser reconhecido, em 1934, como membro da Associação Psicanalítica (por conta de seus posicionamentos políticos e de suas críticas a certos aspectos do pensamento freudiano). Após uma peregrinação em busca de abrigo, o cientista exilou-se na Noruega, vivendo nesse país no período 1934-1939. 
Tendo a oportunidade de utilizar um laboratório do Instituto de Pesquisa da Universidade de Oslo, Reich pôde, enfim, integrar os seus estudos clínicos e sociológicos à investigação experimental. Pautando-se por pesquisas de época sobre a eletrofisiologia dos fluidos corporais, o cientista suspeitou que o 'algo mais' deveria ser um fenômeno de natureza elétrica e pôs-se a investigar, entre 1934 e 1936, as variações da bioeletricidade da pele e mucosas em função da condição emocional do indivíduo, especialmente em relação aos estados de prazer e angústia (REICH, 1937/1982b, 1942/1989). ${ }^{12}$

Custeando de seu próprio bolso a construção de um oscilógrafo, Reich utilizou o aparelho para mensurar o potencial bioelétrico periférico em sujeitos que eram submetidos ora a estímulos agradáveis, ora a estímulos desagradáveis. Entre suas descobertas, ele constatou que, em indivíduos que seriam orgasticamente potentes, o potencial elétrico de uma dada região aumentava quando (e exclusivamente) o sujeito da pesquisa experienciava uma sensação de prazer (se a estimulação não fosse acompanhada de uma impressão agradável, o instrumento não acusava aumentos de potencial). Por outro lado, estímulos desagradáveis (angustiantes, desconfortáveis, dolorosos) produziam, de acordo com as observações de Reich, uma diminuição da bioeletricidade da pele. Ao investigar laboratorialmente, por exemplo, a ereção peniana, ele relatou que apenas havia

\footnotetext{
${ }^{12}$ Nesses experimentos é possível constatar a influência determinante do médico e patologista austríaco Friedrich Kraus (1858-1936). Em resenha escrita em 1927 para a "Internationale Zeitschrift für Psychoanalyse" (IZP), Reich, estabelecendo relações entre as ideias de Kraus e a teoria psicanalítica, já cogitara, como explica um comentador, que a "libido somática de Freud é idêntica à carga bioelétrica do corpo" (NASSELSTEIN, 2007) [a resenha foi intitulada "Kraus, Prof. Fr.: Allgemeine und spezielle Pathologie der Person, klinische Syzygiologie, besonderer Teil I: Tiefenperson" (Kraus, Prof. F.: Patologia geral e específica do indivíduo. Syzigiologia clínica. Em especial, a parte 1: A pessoa profunda") e publicada na IZP, XIII(3), p. 338-339, 1927]. Em sua autobiografia de 1942, Reich, entre outras referências a Kraus, comentou: "Valendo-se de experimentos pioneiros, Kraus, médico internista em Berlim, verificou que o corpo é governado por processos elétricos, compondo-se de incontáveis 'superfícies fronteiriças' entre as membranas e os fluidos eletrolíticos, fluidos esses que apresentam diferentes densidades e composições” (REICH, 1942/1989, p. 273, tradução nossa).
} 
elevação da carga bioelétrica do órgão quando a tumescência era acompanhada de sensações eróticas: "O pênis pode ficar totalmente ereto sem que haja um aumento de potencial. A elevação do potencial está sempre associada a sensações subjetivas de prazer e vice-versa" (REICH, 1937/1982b, p. 84, tradução nossa, grifo do autor). ${ }^{13}$

Calcado nesses experimentos e em sua experiência clínica, Reich julgou ter identificado uma 'fórmula do orgasmo' sequenciada em quatro tempos. A experiência orgástica, na visão reichiana, iniciar-se-ia com a intumescência ou tensão mecânica dos tecidos, especialmente dos órgãos genitais; essa turgescência seria seguida, na ausência de condições patológicas, de um aumento da carga bioenergética na periferia corporal; ocorreria então a descarga orgástica dessa energia perifericamente acumulada, por meio de convulsões involuntárias da musculatura; por fim dar-se-ia o relaxamento mecânico, com refluxo dos fluidos corporais. Em suma: tensão mecânica > carga bioenergética > descarga bioenergética > relaxamento mecânico (REICH, 1942/1989, 1948/1973e). No âmbito dessa abordagem bioenergética, o autor também caracterizou o orgasmo como um processo de expansão (intumescimento e carga) e contração (descarga e relaxamento) (REICH, 1950d).

A alternância entre expansão e contração, por sua vez, não se limitaria, de acordo com as pesquisas de Reich, ao fenômeno orgástico. Ela se manifestaria, também, em certas funções corporais globais e em órgãos específicos, fazendo-se

\footnotetext{
${ }^{13}$ Dois pesquisadores reichianos - Byron Braid e Robert A. Dew - refizeram os experimentos bioelétricos e publicaram, em 1988, os resultados de suas investigações. Apesar de algumas pequenas discrepâncias em relação às pesquisas bioelétricas reichianas, eles afirmaram ter confirmado "muitas observações e conclusões" (BRAID; DEW, 1988, p. 17, tradução nossa) relatadas por Reich. Ao longo desta tese, voltaremos a examinar esses experimentos biolétricos, pois foram fundamentais para a formulação das proposições sensorialistas reichianas.
} 
especialmente visível na pulsação cardíaca e na peristalse intestinal. Dessa perspectiva, o orgasmo humano expressaria tão somente uma variação do mais amplo fenômeno orgânico da tensão > carga > descarga > relaxamento (a especificidade do orgasmo residiria em sua descarga, caracterizada por contrações do tipo rítmico-convulsivas).

O cientista acreditava, ainda, que o processo a quatro tempos iria além da biologia humana e poderia ser facilmente observado, por exemplo, no movimento pulsátil - expansão (tensão-carga) e contração (descarga-relaxamento) - das águas-vivas (REICH, 1950d) e outros animais: "Nos moluscos do mar por mim observados, a alternância entre expansão e contração era extremamente evidente” (REICH, 1938/1979, p. 20, tradução nossa). Pareceu-lhe, em suma, que aquele específico agenciamento de funções mecânicas e bioenergéticas (sintetizado como expansão-contração) teria raízes filogenéticas profundas, representando um fator regulador essencial no domínio da vida. ${ }^{14}$

Sem jamais desconsiderar os fatores psíquicos associados à experiência do orgasmo humano, o autor insistiu, entretanto, que a convulsão orgástica deveria ser vista como um "fenômeno elementar natural" (REICH, 1934/1982c, p.19, tradução nossa, grifo do autor) de caráter “transpsicológico” (REICH, 1951/1973b, p. 290, tradução nossa, grifo do autor), ou seja, um fenômeno que tomaria raízes no funcionamento básico da matéria viva. Por isso, considerou legítimo afirmar que

\footnotetext{
${ }^{14}$ Partindo do pressuposto (como veremos em detalhes, mais adiante) de que haveria uma camada biológica filogeneticamente arcaica, comum a unicelulares e multicelulares e regulada pelo princípio da expansão-contração, Reich, ao se referir a esse primitivo nível de funcionamento, empregava o termo expansão no sentido de dilatação ou alongamento e o termo contração no sentido de encolhimento ou fechamento, sem que essa retração denotasse, necessariamente, algum tipo de disfunção. Para o autor, o fenômeno da contração-expansão em seres vivos indicaria, em suma, duas direções básicas: "tendência para se tornar esférico" e "tendência para se tornar alongado" (REICH, 1934/1982a, p. 44, tradução nossa).
} 
sua "fórmula do orgasmo" expressaria, em última instância, uma "“fórmula da vida’” (REICH, 1950/1990e, p. 7, tradução nossa).

O cientista, em suma, chegou à conclusão, em um primeiro momento, que a vivência orgástica, do ponto de vista bioenergético, poderia ser reduzida a um processo a quatro tempos: tensão mecânica > carga bioenergética > descarga bioenergética > relaxamento mecânico. Partindo dessa fórmula do orgasmo ou processo expansão-contração, Reich, empreendendo outras pesquisas, julgou ter descoberto, em um segundo momento, que aquela sequência quaternária também se manifestaria em certas funções orgânicas globais e em cada órgão do corpo. E pareceu-lhe, por fim, que a alternância entre expansão e contração não se faria presente apenas no fenômeno do orgasmo ou no funcionamento dos órgãos, mas representaria, também, um princípio filogenético mais amplo, ao qual ele denominou de fórmula da vida.

Dirigindo-se cada vez mais para o campo da ciência natural, Reich, desde suas averiguações eletrofisiológicas, não mais se afastou da investigação experimental, exercendo-a, juntamente com outras atividades (atendimento clínico, reflexão sociológica, estudos epistemológicos, projetos de índole social), até o término de sua produção. No final de 1935, na sequência de seus estudos laboratoriais sobre as modulações da bioeletricidade, ele deu início a uma série de experimentos microbiológicos, motivado por várias indagações. Procurando aprofundar seus estudos sobre o encadeamento tensão > carga > descarga > relaxamento, Reich julgou fundamental averiguar em que medida os seres unicelulares estariam submetidos àquele processo quaternário, pois assim ele poderia obter dados que, ou trariam comprovações adicionais ou o obrigariam a reavaliar o grau da generalidade de sua fórmula da vida (REICH, 1938/1979); 
caberia inclusive pesquisar, ponderou o autor, se aquele fenômeno a quatro tempos seria relevante na própria origem ou formação da vida (REICH, 1953/1976b). Ele pretendia investigar, ainda, se sua formulação quaternária permitiria estabelecer alguma interface entre o domínio do vivo e o do não vivo, posto que nesse último também se manifestam processos de carga e descarga elétricas, e de tensão e relaxamento mecânicos. O autor, em suma, indagava: "De que forma se constitui a linha fronteiriça entre o vivo e o não vivo? Há uma nítida demarcação? Há transições?” (REICH, 1950/1990e, p. 7, tradução nossa, grifo do autor).

Tendo em mente o caráter expansivo ou dilatador do fenômeno da tensão > carga, o cientista, a partir de 1936, submeteu diversos tipos de substâncias (carbono pulverizado, grama, terra, areia, entre outras) a processos de intumescimento ou inchação. Simplesmente depositando o material em meio aquoso ou, mais frequentemente, esterilizando os preparados (certas substâncias eram até mesmo incandescidas) e inserindo-os em meios de cultura, o autor pôs-se a acompanhar, por meio de potentes microscópios óticos, o processo de desenvolvimento da mistura ou o "efeito desintegrador" promovido pela combinação de "aquecimento e intumescimento" (REICH, 1938/1979, p. 115, tradução nossa). Procedendo a pacienciosas observações, Reich acreditou ter identificado, nas culturas, a presença de singulares vesículas microscópicas. Tais vesículas, de acordo com as observações do autor, surgiam mais rapidamente quando a substância-base (por exemplo, grama ou pó de carbono) sofria aquecimento, e ele as interpretou como resultado da decomposição, dissociação ou desintegração do material intumescido/expandido (fosse ele de origem orgânica ou inorgânica). Nomeando essas vesículas de bions, o cientista insistiu em seu caráter “especificamente biológico” (REICH, 1948/1973e, p. 15, tradução nossa), 
procurando indicar, assim, que os bions seriam dotados de propriedades vitais que os diferenciariam da matéria inanimada que está exclusivamente sob o efeito de forças mecânicas.

Reich afirmou ter observado nas vesículas bionosas uma evidente motilidade espontânea (de origem interna) que se expressaria como um movimento pulsatório ou alternância entre expansão e contração (nessa propriedade pulsátil o autor teria encontrado uma comprovação adicional de sua fórmula da vida). Os bions manifestariam, mais propriamente, um caráter "bioenergético" (REICH, 1948/1973e, p. 27, tradução nossa, grifo do autor): por um lado, eles se comportariam como "vesículas de energia", dada sua pulsatilidade de natureza interna e seu potencial para atrair e absorver outras vesículas, entre outras características; por outro, seriam semelhantes a uma típica célula, posto que apresentavam membrana, conteúdo líquido e, às vezes, “um núcleo pequeno e fortemente refrativo" (REICH, 1952/1992d, p. 9, tradução nossa).

Em diversas oportunidades, o cientista definiu os bions como "formas transicionais entre a matéria viva e a matéria não viva” (REICH, 1948/1973e, p. 15, tradução nossa, grifo do autor). Para chegar a essa conclusão, ele se apoiou em suas perseverantes observações, que, às vezes, se estendiam por meses e anos.

Reich teria notado, em um primeiro momento, que os bions se desprendiam, pouco a pouco, das substâncias intumescidas (as vesículas eram mais facilmente visualizáveis, de acordo com os relatos reichianos, quando a substância-base sofria aquecimento antes de ser submetida ao intumescimento no caldo de cultura). Mas o autor também afirmou ter notado - valendo-se de observações in loco e de filmagens das culturas - que os preparados continham, por vezes, não apenas vesículas individuais, mas também “"aglomerados de bions”" (REICH, 1952/1992d, 
p. 10, tradução nossa). Após passarem por alguns estágios de desenvolvimento, esses agrupamentos de vesículas poderiam, por sua vez, dar origem, a julgar pelos estudos reichianos, a certos organismos unicelulares, tais como amebas e paramécios.

Por meio de fotos e filmes o autor procurou registrar o desenvolvimento daqueles bions ou vesículas transicionais: seu surgimento nas bordas da substância intumescida, sua motilidade interna e deslocamento no meio de cultura, sua tendência a se aglutinar e, por fim, a transformação dos aglomerados bionosos em seres unicelulares (REICH, 1938/1979, 1948/1973e). Para o cientista, o bion seria essencialmente um elemento fronteiriço (dado que as vesículas nasceriam da dissociação da matéria morta ou da matéria inorgânica e teriam potencial, sob certas condições, de propiciar a formação de seres vivos unicelulares) e representaria a "unidade de funcionamento elementar de toda a matéria viva" (REICH, 1948/1973e, p. 15, tradução nossa, grifo do autor). ${ }^{15}$

Em janeiro de 1939, uma assistente do laboratório de Reich, em Oslo, pretendia demonstrar a um observador o processo de produção de bions a partir de

\footnotetext{
${ }^{15}$ Essa nossa exposição sobre os experimentos bions precisa ser vista como um resumo bastante sintético. Como os abordamos de maneira bastante panorâmica, não pudemos examinar importantes detalhes técnicos envolvidos na pesquisa, nem resgatar as lutas teóricas que o autor travou com biólogos da época (esforçando-se em demonstrar a veracidade de suas formulações), nem apontar as diversas aberturas investigativas geradas, na produção reichiana, pelos experimentos em pauta (como os estudos de Reich a respeito do câncer). Cabe pontuar, porém, que o autor deixou relatos amplos e pormenorizados sobre esses experimentos, tendo-os realizado durante vários anos. Vale mencionar, ainda, que em 1937 Reich enviou uma cultura de bions a Académie des Sciences, em Paris, a qual designou um cientista para averiguar o material. Esse cientista reconheceu a presença, na cultura, de movimentações típicas de seres vivos, mas propôs que Reich publicasse, na Académie, apenas uma parte de suas análises (deixando de lado suas hipóteses bioelétricas e outras confirmações do experimento que teriam surgido na época), seguida de uma interpretação redigida pelo examinador. Discordando dessa interpretação e julgando que a publicação não retrataria a complexidade teórica e técnica de suas pesquisas, o autor não aceitou o convite (REICH, 1948/1973e). Mais recentemente, pesquisadores reichianos vêm reproduzindo os experimentos bions, relatando, em publicações técnicas, terem comprovado as descobertas reichianas (Cf. CAREY; DUNLAP, 1988). No entanto, os estudos de Reich sobre os bions ainda aguardam, a nosso ver, um debate mais extenso que leve em conta não apenas as questões técnicas associadas à reprodutibilidade laboratorial, mas também os pressupostos teórico-metodológicos do experimento e sua significação em relação à história da biologia.
} 
terra, mas se enganou e submeteu areia do mar à incandescência. Disso teria resultado uma cultura de bions diferente das que o autor vinha encontrando, a começar pela grande dimensão das vesículas, que mediriam "entre dez e quinze micra” (REICH, 1948/1973e, p. 82, tradução nossa). Chamou a atenção do cientista, também, o fato de as vesículas de bions de areia produzirem manchas em placas fotográficas, inflamações oculares nos observadores das culturas, manifestações luminosas em ambientes escuros, entre outros fenômenos. Esses eventos sugeriam, ponderou o autor, a presença de algum tipo de radiação (testes demonstraram, na época, que não se tratava de radiação nuclear). Reich dedicouse, então, a construir um aparato que possibilitasse acumular $\mathrm{e}$ isolar aquela radiação, para melhor estudar seus efeitos.

Observações e experimentos realizados em seu laboratório sugeriam que a matéria orgânica absorvia a radiação em pauta, e a matéria inorgânica a refletia. Tendo em vista esses indicadores, o cientista construiu, para tentar confinar a radiação, uma caixa com paredes internas de metal e revestimento externo de material orgânico (a radiação que não fosse refletida ou 'devolvida' para dentro da caixa pelo metal, seria, ao menos parcialmente, retida ou absorvida pela camada exterior, minimizando assim sua perda). Após depositar, no interior do aparato, cerca de uma dúzia de culturas de bions de areia, o autor e seus colaboradores teriam efetivamente observado, segundo os comunicados reichianos, diversos fenômenos luminosos que se assemelhariam a "vapores azulados em movimento, riscos brilhantes amarelo-esbranquiçados e pontos de luz" (REICH, 1948/1973e, p. 91, tradução nossa). Esses fenômenos representariam, no entendimento do cientista, importantes manifestações objetivas da singular radiação emanada pelos bions de areia do mar. 0 autor relatou, no entanto, logo ter percebido que aqueles 
mesmos sinais luminosos também surgiam, ainda que com intensidade menor, nas caixas acumuladoras que não haviam recebido as culturas de bions de areia. Sentindo-se intrigado, ele se perguntava “de onde vem a radiação?" (p. 92, tradução nossa, grifo do autor).

Em agosto de 1939, Reich se mudou para os EUA, desenvolvendo suas pesquisas nesse país até sua morte em 1957. Durante uma viagem ao Maine, no verão de 1940, ele pôs-se a olhar o céu noturno e, para sua surpresa, acreditou ter visualizado "o mesmo tremeluzir delicado e lampejante, com pontos e riscos de luz" (REICH, 1948/1973e, p. 92, tradução nossa) que observara frequentemente em seu aparato de acumulação. Subsequentes averiguações e experimentos o levaram a concluir que a caixa em questão, construída inicialmente para isolar a radiação bionosa, sempre exibia os característicos fenômenos luminosos (mesmo na ausência dos bions de areia) porque o aparato estaria retendo, na verdade, uma radiação ou energia proveniente da própria atmosfera. ${ }^{16}$ Bastante atento e sensível àqueles específicos sinais luminosos desde que montara as caixas acumuladoras, Reich, em suma, teria notado uma semelhança entre as manifestações que observara no aparato e na atmosfera.

Amparando-se em outra série de pesquisas laboratoriais, o autor julgou contar com dados experimentais suficientes para postular que a radiação que teria emanado da cultura de bions de areia, os efeitos luminosos que teriam se apresentado no aparato de acumulação (contendo ou não preparados bionosos) e os fenômenos cintilantes que teriam sido visualizados na atmosfera apresentavam propriedades comuns e remetiam a uma mesma energia. Denominando-a de energia

\footnotetext{
${ }^{16}$ Em 1940, Reich passou a denominar o aparato de "acumulador de energia orgone" (ORGONE INSTITUTE PRESS, 1953, p. 5, tradução nossa).
} 
orgone e fundando um campo de pesquisas para estudá-la - a Orgonomia -, o cientista mostrou-se convicto, a partir de 1940, que a radiação ou energia em questão agiria nos domínios do vivo e do não vivo e seria fundamentalmente distinta dos processos energéticos descritos pela Física (REICH, 1948/1973e). Até o final de sua produção, ele empreendeu volumosas e diversificadas pesquisas a respeito da energia orgone, procurando caracterizar suas propriedades básicas, pontuar suas diferenças com outras formas de energia (tais como a eletromagnética, térmica e nuclear), estudar suas principais manifestações nos campos do vivo e do não vivo e demonstrar seu papel terapêutico.

Com o propósito, como comentamos anteriormente, de facilitar nossa caminhada pelo tema da sensação na obra reichiana, mencionaremos, logo a seguir, algumas propriedades que Reich julgou identificar na energia orgone. Não poderemos, porém, nos aprofundar no tema, por três razões.

A primeira razão diz respeito ao fato de que não é possível avaliar de forma detalhada as intricadas rotas investigativas e as formulações da fase orgonômica reichiana (1939-1957) sem se proceder ao resgate de temas técnicos pertencentes a diversas áreas do conhecimento, tais como Eletromagnetismo, Meteorologia, Astrofísica, Biologia Evolutiva, Microbiologia, Bioquímica, além da História da Ciência e Epistemologia, pois o autor, em suas pesquisas sobre a energia orgone, esbarrou de uma forma ou de outra nessas disciplinas, travando, não raramente, acirradas batalhas teóricas e experimentais com cientistas de sua época. Situar as proposições orgonômicas em relação a tais setores do conhecimento é uma empreitada que, apesar do vasto material redigido pelo próprio autor a esse respeito, extrapola nossos propósitos e possibilidades, aqui. 
A segunda dificuldade está associada ao fato de que um exame da orgonomia reichiana requer não apenas o detalhado resgate das pesquisas experimentais do autor, mas também, de sua específica concepção epistemológica acerca da dinâmica e interligação das funções naturais. Reich deu à forma mais elaborada dessa concepção o nome de Funcionalismo Orgonômico ou Funcionalismo Energético e procurou demonstrar que seu funcionalismo teria sobrepujado diversas limitações que as visões de mundo mecano-materialistas e espiritualistas imporiam à investigação científica. 0 autor se interessou profundamente, ao longo de sua obra, pela epistemologia da produção científica e é tão íntima a associação que ele estabeleceu, em seu próprio trabalho, entre teoria e método, que se torna praticamente impossível dissociar o percurso experimental reichiano de suas sustentações epistêmicas. Avaliar essa retroalimentação entre pesquisa científica e pesquisa epistemológica (ainda que Reich tenha, também nesse caso, redigido textos específicos sobre o assunto) é outra tarefa que transcende o escopo do presente estudo. O máximo a que chegaremos, no quinto capítulo desta tese, será o exame de um aspecto específico do programa epistemológico reichiano: o que diz respeito ao papel da sensorialidade na produção do conhecimento científico.

Há, por fim, um terceiro fator dificultando uma análise mais precisa das formulações orgonômicas: a escassez de estudos críticos que contemplem, tanto o atual estágio de desenvolvimento da Orgonomia, quanto as críticas sérias a ela. A história da pesquisa em Orgonomia conta, em sua primeira fase, com uma grande quantidade de trabalhos publicados por Reich ao longo de quase duas décadas, nos quais ele descreveu detalhadamente suas teorias gerais, experimentos laboratoriais e pressupostos epistemológicos. Vários desses estudos foram reproduzidos, após o falecimento do autor, por alguns grupos reichianos que, em suas publicações, 
relatam frequentes confirmações das proposições orgonômicas (Cf. HUGHES, 1982; BAKER, 1985). Tais replicações permanecem, no entanto, vinculadas, em sua maior parte, a instituições estritamente reichianas (que, bravamente, vêm mantendo a investigação viva), mas ainda não foram alvo de um amplo debate científicoacadêmico que contemplasse as possíveis provas laboratoriais acerca da energia orgone e suas bases epistemológicas. Isso se deve, em boa parte, às duras críticas que a Orgonomia vem recebendo desde seu nascimento, empreendidas basicamente, em nossa opinião, por dois grupos. 0 primeiro grupo se caracteriza por rechaçar a priori as teorias orgonômicas; considerando-as uma completa insanidade, esse grupo se recusa, de imediato, a reconhecer qualquer status científico nas provas experimentais descritas por Reich e não vê sentido, portanto, em replicar os experimentos. 0 outro grupo, por sua vez, chega mais perto das formulações orgonômicas, mas as questiona enfaticamente a partir de critérios científicos e epistemológicos gerais (como certas diretrizes básicas da Física e Biologia atuais), julgando que os dados experimentais ofertados por Reich para comprovar a existência da energia orgone são duvidosos ou mesmo equivocados; do ponto de vista desses críticos, os fenômenos nos quais o autor teria reconhecido evidentes manifestações de uma energia especial poderiam ser facilmente explicados por meio das formas conhecidas de energia ou outras proposições de caráter físico e/ou químico.

Pode-se dizer, em suma, que as formulações da Orgonomia fazem parte, hoje, de um quadro bastante complexo, que engloba os relatos redigidos pelo autor e seus colaboradores no período 1939-1957, a replicação de boa parte desses experimentos por grupos reichianos, as críticas (com maior ou menor fundamentação) a respeito da energia orgone e a escassez de estudos orgonômicos 
(experimentais e epistemológicos) em instituições gerais de pesquisa. Apesar da complexidade envolvida, uma análise detalhada desse contexto permitiria, a nosso ver, ultrapassar seja a crítica rasteira, seja a adesão cega. Não temos, porém, possibilidades de empreender tal pesquisa aqui. ${ }^{17}$

Feitas essas ressalvas, destacaremos, a seguir, algumas características que o cientista acreditou ter identificado na energia orgone. Nosso objetivo, dadas as razões acima apresentadas, não é o de empreender uma discussão crítica sobre as asserções orgonômicas reichianas, mas sim, introduzir alguns conceitos indispensáveis para um melhor entendimento do tema da sensorialidade na obra do autor.

Da diversificada investigação orgonômica reichiana, selecionamos quatro tópicos:

a) A diferenciação entre processos energéticos primários e secundários. Experimentos laboratoriais teriam indicado a Reich que os processos orgonóticos (tais como os que teriam se evidenciado nas caixas acumuladoras, anteriormente descritas) ocupariam todo e qualquer espaço físico (REICH, 1992a, 1948/1973e). O cientista se sentiu, assim, autorizado a falar em "energia orgone cósmica” (REICH, 1951/1973b, p. 173, tradução nossa) ou “força criativa primordial” (p. 283, tradução nossa). Suas pesquisas teriam the indicado, inclusive, que as formas de energias descritas pela Física, assim como a matéria inanimada e, até mesmo, a matéria viva emergiriam, por meio de "complicados processos de diferenciação",

\footnotetext{
17 Reich tinha poucas esperanças de que o meio científico revisse com isenção suas elaborações orgonômicas, pois, a seu ver, a maior parte dos pesquisadores padeceria de uma crônica formatação mecanicista. Essa rígida formatação distanciaria os cientistas das manifestações profundas da vida (tais como a convulsão orgástica) e, consequentemente, os impediria de compreender a lógica investigativa que, partindo do estudo do orgasmo, teria conduzido à descoberta de uma energia primordial, atuante nos domínios do vivo e do não vivo (REICH, 1949/1973C). Retomaremos, mais adiante, esse posicionamento reichiano.
} 
dessa “energia cósmica primordial” (REICH, 1949/1973c, p. 99, tradução nossa). Estabelecendo uma diferenciação entre processos energéticos primários (as forças orgonóticas) e secundários (as formas tradicionais de energia) (REICH, 1952/1992d), o autor acreditava (e tentou demonstrar laboratorialmente) que determinados fenômenos físicos, tais como a eletricidade estática e o eletromagnetismo, derivariam de um fator mais amplo e primordial, a energia orgone cósmica (REICH, 1944/1991a, 1944/1992b). Convicto que os processos orgonóticos agiriam, também, em seres vivos, o autor reavaliou seus experimentos bioelétricos, interpretando, agora, os potenciais elétricos da pele como uma variação ou manifestação secundária da energia orgone atuante no organismo humano (REICH, 1952/1991b). ${ }^{18}$

b) O fenômeno da pulsação. A integração de distintas pesquisas - o estudo do sistema nervoso autônomo, a observação dos pulsos internos e do deslocamento espacial dos bions, as averiguações laboratoriais (em caixas e salas acumuladoras) e em campo aberto (como no topo de montanhas), a análise de certos fenômenos atmosféricos (tais como auroras boreais e furacões) e astrofísicos (especialmente, galáxias espirais), entre outras investigações - teriam revelado ao autor que a energia orgone se propagaria, em seu estado mais básico, de forma pulsátil. Essa pulsatilidade se expressaria, mais precisamente, por uma conjugação de dois tipos de movimentos: movimento espiralado (função onda) e movimento de contraçãoexpansão (função pulso). Uma representação gráfica do fenômeno seria a de um ponto que contrai-expande enquanto trafega de modo espiralado pelo espaço; a esse respeito, o autor fez a seguinte anotação em seu diário, em 26 de novembro

\footnotetext{
${ }^{18} \mathrm{~A}$ concepção reichiana a respeito da natureza pode ser claramente observada em uma nota que o autor inseriu, em 1952, em um de seus diários. Lê-se nessa nota que o universo, quando encarado funcionalmente, revelar-se-ia "pleno de energia, pulsando em variados ritmos, sempre em estado de desenvolvimento e mudança". Esse cosmo seria "funcional", pois seu comportamento não se acomodaria nem à lógica "mecanicista”, nem a qualquer concepção “mística” (REICH, 1999, p. 248, tradução nossa).
} 
de 1948: "Pulsação funciona SIMULTANEAMENTE em suas variações, pulso e onda" (REICH, 2012, p. 24, tradução nossa, grifo do autor). A pulsação orgonótica ${ }^{19}$ também alcançaria, de acordo com as pesquisas do autor, o domínio do vivo, sofrendo então reconfigurações impostas pelos limites materiais próprios a cada criatura vivente. A pulsatilidade orgonótica poderia ser identificada em diversas manifestações, tanto da esfera orgânica, quanto da esfera inorgânica, como, por exemplo, na aurora boreal - fenômeno que apresentaria "um caráter lento, ondulatório, por vezes pulsátil, semelhante a ondas” (REICH, 1951/1973b, p. 241, tradução nossa) -, na movimentação dos vermes - animais em que se visualizaria com facilidade "ondas pulsatórias de excitação" (p. 204, tradução nossa) propagando-se da cauda em direção à cabeça - e, com especial nitidez, na peristalse intestinal.

c) A função de superposição. No entendimento do cientista, o indivíduo humano deveria ser visto como um "fragmento especialmente organizado da energia orgone cósmica" (REICH, 1951/1973b, p. 176, tradução nossa) e como um “sistema de energia, não apenas como psiquismo" (REICH, 2012, p. 44, tradução nossa). Interessado em localizar os fatores que coligariam o humano à natureza, ele insistiu que essa identidade não poderia ser buscada, por exemplo, nas complexas funções de pensamento e linguagem. Também não poderia ser buscada na fórmula quaternária tensão > carga > descarga > relaxamento, pois esse sequenciamento seria exclusivamente válido, segundo o autor, para os seres vivos, não podendo ser estendido ao domínio inanimado (apesar de haver, na natureza não viva, fenômenos de tensão e carga, e de descarga e relaxamento mecânicos, o

\footnotetext{
${ }^{19}$ Cabe realçar que o autor diferenciou entre pulsação, pulso e onda; a pulsação seria uma função mais ampla, da qual derivariam o pulso (contração-expansão) e a onda (propagação espiralada).
} 
encadeamento progressivo das quatro funções ocorreria exclusivamente na esfera do vivo). O autor localizou aquela identidade ou "princípio de funcionamento comum" (REICH, 1950a, p. 175, tradução nossa) em um fenômeno por ele denominado de "superposição cósmica” (título, também, de obra publicada pelo autor em 1951 - Cosmic Superimposition); podendo ocorrer no âmbito do humano e da natureza em geral, a superposição seria o fator comum ou unificador que Reich procurara por um longo período. Analisando, tanto no micro quanto no macrocosmo, a forma de interação dos fluxos orgonóticos, o cientista acreditou ter descoberto que, sob certas condições, correntes ondulares de energia orgone podem se atrair, estabelecendo uma superposição e consequente fusão (por meio de experimentos, ele procurou demonstrar, também, que a matéria, em suas diferentes configurações, estaria continuamente emergindo a partir desse processo de fusão ou superposição cósmica). Em seres humanos, a experiência da potência orgástica representaria uma importante expressão da “superposição e fusão bioenergética de dois sistemas orgonóticos” (REICH, 1951/1973b, p. 181, tradução nossa). No domínio macroscópico o fenômeno seria bem retratado pelas nebulosas espirais, cuja forma e disposição de seus braços levou o autor a supor que elas poderiam ter se originado da atração de correntes orgonóticas cósmicas espiraladas e de sua superposição; a própria Via Láctea, como lembrou o cientista, é uma galáxia espiral (REICH, 1951/1973b).

d) A propriedade de movimento espontâneo. A julgar pelos estudos e experimentos reichianos, a energia orgone seria, antes de tudo, automovente ou 'espontânea'. Como apontou um comentador, Reich via no “movimento espontâneo" uma das “características mais básicas” (BAKER, 1997, p. 9, tradução nossa) da energia orgone. Essa capacidade de mover-se por si mesma e, assim, 
prescindir, para sua motilidade, da ação de quaisquer forças externas a ela, seria especialmente evidente no estado livre de massa (ou primário) da energia orgone. Para o autor, tal propriedade do automovimento teria sido repassada, por assim dizer, aos seres vivos e mesmo à atmosfera do planeta (REICH, 1951/1973b), mas, nesses casos, a 'espontaneidade' da pulsação orgonótica não ficaria completamente imune às determinações físico-químicas. Juntamente com a já mencionada diferenciação entre a energia primária (a energia orgone) e as energias secundárias (os tradicionais processos energéticos), o autor também insistiu na distinção entre energia orgone livre de massa e energia orgone coligada à massa. Julgando ter comprovado, a partir de uma série de experimentos, que as estruturas materiais nada mais seriam do que energia orgone condensada, e que as criaturas vivas e a atmosfera representariam uma combinação entre energia orgone congelada (ou seja, a massa) e funções orgonóticas que teriam se mantido em fluxo, o autor procurou demonstrar que a propriedade do automovimento continuaria existindo, ainda que com limitações, em sistemas em que a matéria desempenha importante papel (REICH, 1951/1973b). Haveria, na visão do autor, uma dependência recíproca ou mútua influência entre elementos estruturalizados (massa) e as funções orgonóticas que teriam preservado certa capacidade de automovimento (BAKER, 1987). As funções vegetativas autônomas e as auroras boreais seriam dois exemplos de automovimento, circunscritos, porém, por estofos materiais.

Sempre buscando por fatores de base ou denominadores comuns de distintos territórios (micro e macrocosmo, vivo e não vivo), o autor identificou diversas outras propriedades na energia orgone e haveria, inclusive, muito mais a dizer em relação às características acima descritas. Mas não seguiremos adiante, dado o 
caráter meramente introdutório de nossa apresentação sobre o percurso reichiano no campo da energia. Como mencionamos anteriormente, nada mais pretendemos, com essa breve síntese, do que preparar o terreno para as averiguações que levaremos a cabo, mais adiante, sobre as teses sensorialistas reichianas.

Voltemos, agora, à questão do protoplasma. Afinal, a pesquisa reichiana, como o próprio autor admitiu, teve como ponto de partida e linha condutora " $a$ função da pulsação orgástica do plasma" (REICH, 1949/1973c, p. 5, tradução nossa, grifo do autor).

\subsection{Função protoplasmática}

Após essa brevíssima incursão pelos estudos que Reich endereçou à energia, poderemos examinar suas proposições, de teor marcadamente energético, a respeito do protoplasma. Faz-se necessário retomar, como comentamos anteriormente, o entendimento do autor acerca do protoplasma, pois, a seu ver, o fenômeno da sensação estaria diretamente coligado ao funcionamento plasmático.

Vimos há pouco que os biólogos da segunda metade do século XIX e início do século XX haviam interpretado o protoplasma de, ao menos, quatro perspectivas: (a) como substância gelatinosa especialíssima (posto que seria a base do fenômeno da vida), (b) como substância indiferenciada (mas potencialmente capaz de originar elementos mais estruturados), (c) como substância dotada de movimento contrátil (ou motilidade espontânea) e (d) como substância irritável (capaz de reagir aos estímulos externos).

$\mathrm{Na}$ etapa orgonômica de sua produção, Reich empregou extensivamente expressões como “plasma contráctil” (REICH, 1948/1973e, p. 30, tradução nossa), 
"sensações e correntes plasmáticas" (REICH, 1945/1973a, p. 60, tradução nossa), “sistema plasmático vivo" (REICH, 1948/1973e, p. 153, tradução nossa), “pulsação orgástica do plasma" (REICH, 1949/1973c, p. 5, tradução nossa, grifo do autor), entre outras noções correlatas. Ainda que, na obra reichiana, essas denominações apareçam com mais frequência no contexto das pesquisas orgonômicas das décadas de 1940 e 1950, elas tiveram como inspiração, certamente, a teoria protoplasmática da segunda metade do século XIX e primeiras décadas do século $X X$.

Na obra The Cancer Biopathy (“A biopatia do câncer”), publicada em 1948, o autor endereçou algumas apreciações curtas, mas significativas, ao conceito de protoplasma, situando-o antes de tudo nos embates entre a abordagem "funcional" e a perspectiva mecano-materialista: "na moderna literatura em biologia, desde aproximadamente a I Guerra Mundial, a abordagem funcional avançou ligeiramente em relação ao ponto de vista substancialista-mecanicista". ${ }^{20}$ Apesar desse relativo avanço (do estrito substancialismo físico-químico para uma incipiente perspectiva

\footnotetext{
${ }^{20}$ Reich foi fortemente influenciado pela moderna concepção de função, chegando a desenvolver, como mencionamos anteriormente, uma perspectiva metodológica de orientação funcionalista (o Funcionalismo Orgonômico ou Energético). 0 embate, mencionado por Reich na citação acima, entre a visão funcional e a concepção substancialista foi amplamente examinado pelo filósofo alemão Ernst Cassirer (1874-1945) na obra Substanzbegriff und Funktionsbegriff ("Conceito de substância e conceito de função"), publicada em 1910. A noção de função, inicialmente forjada no campo da matemática, teria se estendido ao "campo do conhecimento da natureza", constituindo "o esquema geral e o modelo segundo o qual o moderno conceito de natureza foi moldado em seu progressivo desenvolvimento histórico" (CASSIRER, 1910-1921/1953, p. 21, tradução nossa, grifo do autor). De acordo com o pensador alemão, uma nova orientação epistemológica consolidou-se gradualmente nas ciências naturais, orientação essa que, recusando-se a se restringir à listagem das particularidades dos fenômenos, começou a dar especial atenção à dimensão funcional, ou seja, às plásticas inter-relações e processualidades dos acontecimentos. Se antes do surgimento da ciência moderna a preocupação residia em compreender a substância ou essência última dos fenômenos (acreditando-se, muitas vezes, que bastaria identificar e classificar compulsoriamente suas propriedades específicas), com a construção da perspectiva funcional passou-se a atribuir grande importância, também, aos vínculos flexíveis que se estabelecem entre os eventos. Reconhecendo a importância de estudar as propriedades elementares dos fenômenos, mas procurando se libertar do enciclopedismo, a moderna pesquisa científica teria potencial para incorporar os constituintes básicos dos eventos em um quadro extremamente relacional, progressivo e correlativo. Essa visão dinâmico-funcional permeou toda a investigação científica de Reich e foi incorporada, de forma radical, às suas formulações epistemológicas.
} 
funcional e dinamista), a Biologia não teria se libertado, na visão do cientista, de um de seus "problemas cruciais". Esse problema central diria respeito ao fato de que, enquanto certas estruturas corporais - tais como "a musculatura, os nervos, as glândulas" - recebiam cada vez mais atenção da pesquisa experimental, as funções do protoplasma, no entendimento do autor, continuavam sendo vistas como um “milagre” (REICH, 1948/1973e, p. 49, tradução nossa).

Interessante observar que, por volta de 1957-1958, o filósofo francês Maurice Merleau-Ponty (1908-1961) também comentou com seus alunos - ao averiguar, em suas aulas no Collège de France, certas proposições do biólogo Jakob Johann von Uexküll, a quem nos referiremos logo abaixo - que seria mais simples compreender uma estrutura anatômica do que o protoplasma, posto que este último mostrar-seia “muito mais prodigioso" (MERLEAU-PONTY, 1995, p. 223, tradução nossa). Nessa condição de miraculoso e prodigioso substrato da vida, o conceito de protoplasma corria o risco, de fato, de transcender a reflexão científica e dar margem à especulação teológica (CORREA, 1998).

Ainda que se recusasse a acreditar na existência de um "'espírito' personificado ou absoluto" (REICH, 1951/1973b, p. 283, tradução nossa) que governaria o universo e se opusesse a qualquer interpretação espiritualista ou metafísica da matéria viva (REICH, 1942/1989), o autor, como comentamos anteriormente, mostrou-se simpático a certas teses vitalistas, como as que combatiam a visão de que o protoplasma poderia ser plena e exclusivamente reduzido às suas propriedades físicas e químicas:

O protoplasma é fundamentalmente diferente de uma máquina, posto que 'máquinas fluidas são inconcebíveis' (Uexküll). 0 protoplasma funciona a partir de características que não estão presentes nas máquinas. Ele funciona sem estar estruturado (REICH, 1948/1973e, p. 49, tradução nossa, grifo do autor). 
Observa-se, nessa passagem, menção à condição básica de não estruturação do protoplasma, antecedida de uma referência a Jakob Johann von Uexküll (18641944), biólogo que influenciou significativamente a produção reichiana. Reich, ele próprio, reconheceu essa influência, como se pode observar em uma anotação em seu diário, datada de 20 de novembro de 1943: “[...] sou discípulo e admirador dos grandes mestres que estudei em 1920: Driesch, Loeb, Uexküll, Hertwig, Semon e outros” (REICH, 1999, p. 206, tradução nossa). Em trabalho publicado em 1920, Theoretische Biologie $e^{21}$ - obra que estimulou, em diferentes momentos, a produção reichiana (REICH, 1938/1979, 1948/1973e) -, Uexküll explicou por que o protoplasma funcionaria "sem estar estruturado". Referindo-se aos seres unicelulares - criaturas que, segundo o biólogo, seriam formadas, em seu todo ou em sua maior parte, "por protoplasma" - Uexküll salientou que o conteúdo protoplasmático teria a plástica capacidade de "formar órgãos" e, logo em seguida, de "dissolvê-los":

0 estudo dos infusórios ${ }^{22}$ mostrou que o aparato vegetativo de tais criaturas [...] ainda depende da pura atividade protoplasmática. Seu interior ainda consiste de protoplasma fluido, o qual forma um vacúolo em torno de cada partícula de alimento ingerida; esse vacúolo se torna primeiramente a boca, depois o estômago, a seguir o intestino e, por fim, o ânus. [...] Observamos os órgãos surgirem um após o outro em sequência definida, e cada um deles, quando encerram suas atividades, desaparecem novamente (UEXKÜLL, 1920/1926, p. 123, tradução nossa).

\footnotetext{
${ }^{21}$ Valemo-nos aqui de uma tradução norte-americana deste livro: Theoretical biology (UEXKÜLL, 1920/1926).

${ }^{22} \mathrm{O}$ termo infusório, como indica Anthony Serafini em seu The epic history of biology, alude a um grupo heterogêneo de minúsculos organismos unicelulares: "[o vocábulo] inicialmente referia-se a algas, bactérias e até mesmo a pequenos vermes, mas, posteriormente, passou a designar apenas organismos unicelulares" (SERAFINI, 1993, p. 115, tradução nossa).
} 
Essa plástica motilidade não poderia ser exclusivamente reduzida, na visão reichiana, aos componentes químicos do protoplasma: "A estrutura material (substantive) é, em si mesma, dependente da função do plasma vivo" (REICH, 1948/1973e, p. 49, tradução nossa, grifo do autor). A dimensão bioquímica cumpriria importante papel, mas o caráter vivo do protoplasma tomaria raízes, de acordo com o cientista, em uma "função" energética, ou seja, na energia orgone que operaria no organismo: "Não se trata de uma questão de substância, mas de funções de energia biológica" (p. 30, tradução nossa, grifo do autor).

Fiel a sua orientação de pesquisa - que, em um primeiro momento, priorizava "o movimento e os processos energéticos", não "a matéria ou a estrutura" (REICH, 1949/1973c, p. 112, tradução nossa) -, o cientista ponderou que o "protoplasma vivo", certamente "um complexo proteico", estaria sempre subordinado à ação da "energia orgone livre de massa" (REICH, 1948/1973e, p. 57, tradução nossa, grifo do autor).

O autor ainda realçou, em The Cancer Biopathy, que o protoplasma não funcionaria "de acordo com princípios mecânicos, ou de acordo com princípios metafísicos, finalísticos, mas a partir de funções energético-orgonóticas" (REICH, 1948/1973e, p. 58, tradução nossa, grifo do autor). Pois a energia orgone, dada suas características fenomênicas, imprimiria ao protoplasma um movimento pulsátil espontâneo, com alternância de expansão e contração. A raiz dessa pulsação (ou contratilidade, na linguagem dos pioneiros pesquisadores do protoplasma) deveria ser buscada, insistiu Reich, não em energias mecânicas ou forças extrafísicas, mas na interface entre a energia orgone cósmica e a matéria viva. 
Em suma, o protoplasma, na perspectiva reichiana, apenas se manteria em estado vivo enquanto estivesse coligado às funções orgonóticas do organismo (tais como as operações de expansão e contração). Para o autor, as pesquisas que se limitassem a perscrutar a composição físico-química do protoplasma, deixando de lado a ação das forças orgonóticas primárias, pouco avançariam no entendimento dos processos vitais (REICH, 1948/1973e).

Mas, tratando-se especificamente de seres humanos, haveria, de acordo com a pesquisa reichiana, um sistema modulador, em grande escala, de toda a atividade protoplasmática celular do indivíduo. Como veremos a seguir, esse "sistema plasmático contrátil" representaria, no entendimento do cientista, "a ‘ameba no organismo multicelular'” (REICH, 1937/1982b, p. 125, tradução nossa, grifos do autor).

\subsection{Motilidade vegetativa}

Quando começamos a averiguar o tema da sensação na obra reichiana, comentamos que o cientista partilhou da intrigante tese de que haveria uma rudimentar apreensão sensorial associada ao protoplasma dos organismos vivos, mesmo naqueles que não apresentam sistema nervoso. A partir daí, tomamos alguns atalhos. Retomamos, inicialmente, os significados atribuídos ao protoplasma na Biologia do século XIX e início do século XX e, antes de avaliarmos o entendimento reichiano sobre o tema, recuperamos brevemente os estudos do autor a respeito da energia. Na sequência, pudemos observar que Reich, além de ter absorvido a ideia de que o protoplasma apresentaria alguma sensorialidade, inspirou-se em outros elementos da teoria protoplasmática (como os conceitos de 
contratilidade e não estruturação). Vimos ainda que ele reelaborou tal teoria, especialmente no estágio norte-americano de sua produção, a partir de um ângulo energético (orgonótico), propondo que a chave para se compreender a motilidade plasmática residiria na ação de uma pulsátil energia biológica específica (que ele acreditava ter objetivado e quantificado), não nas configurações físico-químicas em si mesmas.

Tendo em vista especificamente seres humanos, Reich propôs a existência, como veremos a seguir, de uma função vegetativa que coordenaria o movimento plasmático celular do organismo como um todo e estaria diretamente associada ao sistema nervoso autônomo (REICH, 1937/1982b, 1943). Também teremos oportunidade de observar que ele caracterizou o sistema nervoso autônomo ou vegetativo como uma poderosa usina de energia que, tomando raízes em ancestrais estratos biológicos, produziria os assim chamados impulsos motores vitais (os ímpetos diretamente associados e definidores da própria vida) e conteria importantes matrizes da sensorialidade humana.

Verificaremos ainda, que o funcionamento vegetativo, com os impulsos e sensações que lhe seriam próprios, recebeu grande atenção da abordagem clínicoterapêutica reichiana, e que o autor procurou compreender e denunciar os mecanismos sociais autoritários que, em busca de dominação econômica e ideológica, anestesiariam a vitalidade vegetativa humana.

Chegaremos então aos estudos que Reich dirigiu a um tipo de percepção que, a seu ver, estaria diretamente coligado à função vegetativa: as sensações plasmáticas ou sensações de órgão. É a partir dessa noção que começaremos, enfim, a examinar a teorização estritamente reichiana acerca do fenômeno sensorial. 
Nosso trajeto em direção às proposições sensorialistas reichianas exige, contudo, que averiguemos inicialmente o peculiar entendimento do autor acerca da função vegetativa e do papel que o cérebro ocuparia no funcionamento global do indivíduo. Para tal, retomaremos, a seguir, os questionamentos que Reich endereçou a uma neurologia que, a seu ver, seria refém de um posicionamento mecanicista que a impediria de enxergar a dimensão vegetativa como importante matriz energética e sensorial.

\subsubsection{Crítica ao centralismo cerebral}

Além de se mostrar simpático a certos aspectos da teoria protoplasmática e do neovitalismo, o autor demonstrou grande interesse, desde o início de sua carreira, pelo funcionamento do sistema nervoso. Logo após terminar o curso de Medicina, Reich decidiu se especializar em Neuropsiquiatria, estagiando em Viena, entre 1922 e 1924, na Clínica Universitária de Psiquiatria e Neurologia. Ele teve como orientador Julius Wagner-Jauregg (1857-1940), célebre neurologista que recebeu em 1927 o Prêmio Nobel de Medicina por suas pesquisas sobre a malarioterapia, ${ }^{23}$ e contou ainda com a supervisão de Paul Schilder (1886-1940), assistente de Wagner-Jauregg que se tornaria, ele também, um reconhecido neurologista.

Reich, entretanto, começara a trabalhar como psicanalista antes mesmo de se formar em medicina (como mencionamos anteriormente, ele havia sido formalmente aceito em 1920 na Associação Psicanalítica). Sob o duplo impacto do

\footnotetext{
${ }^{23}$ A malarioterapia foi uma técnica que, por meio da indução da malária, mostrou-se eficaz no tratamento de vários casos de paralisia geral progressiva (um distúrbio psiquiátrico causado pela sífilis).
} 
conhecimento médico acadêmico e das intrigantes ideias freudianas, ele não tardou a perceber uma acirrada controvérsia entre "a explicação psicanalítica das doenças psíquicas e a explicação neurofisiológica”, como se “'psicogênico' e 'somatogênico"” tivessem se tornado "antíteses absolutas". Relembrando a fase inicial de sua produção, ele comentou que o "jovem psicanalista que trabalhava no campo da psiquiatria tinha de encontrar seu caminho, de alguma forma, no meio daquela confusão" (REICH, 1942/1989, p. 66, tradução nossa).

Em sua época de estudante de medicina, Reich sentia-se, de acordo com seus relatos autobiográficos, fascinado pela "complexidade dos feixes nervosos"; empenhando-se sobremaneira em seus estudos, ele teria então alcançado uma ampla visão acerca da "anatomia do cérebro e de todo o sistema nervoso" (REICH, 1942/1989, p. 24, tradução nossa). Leitor voraz, o autor procurou se manter atento às "brilhantes e numerosas formulações da moderna literatura fisiológica" (p. 269, tradução nossa). Entre elas, estavam as investigações acerca da fisiologia cerebral, as quais, desde a primeira metade do século XIX, vinham avançando consideravelmente na compreensão da estrutura e função do sistema nervoso (CLARKE; JACYNA, 1987).

Amparada por pesquisas laboratoriais com animais vertebrados (tais como ratos, pombos e cães) e exames clínicos de seres humanos, a fisiologia do sistema nervoso tentava desbravar, com ímpeto investigativo nunca visto, o funcionamento das diversas áreas cerebrais, dos órgãos dos sentidos e das vias neuronais. Frequentemente concebendo o cérebro como "centro da consciência e do controle da ação voluntária" (GOODWIN, 2010, p. 81), as pesquisas exploravam as correlações entre as estruturas cerebrais e a dinâmica psicológica, na 
esperança, muitas vezes, de delimitar o "exato 'lugar'” (CLARKE; JACYNA, 1987, p. 4 , tradução nossa) que a vida anímica ocuparia no sistema nervoso. ${ }^{24}$

Apesar do avanço científico, um forte "preconceito" - de acordo com Reich (e também outros estudiosos, como veremos adiante) - dominaria o "pensamento neurológico e médico em geral” (REICH, 1937/1982b, p. 120, tradução nossa): a ideia de que o cérebro ocuparia, no conjunto do organismo, um papel privilegiado em relação aos demais órgãos e sistemas corporais. Segundo essa tese o cérebro representaria, como afirmou o autor em Ether, God and Devil, o "produto mais ‘elevado’ da evolução”, a ponto de este órgão e o sistema nervoso central serem considerados como dirigentes do "organismo como um todo". Nessa perspectiva o cérebro seria o grande boss; os demais órgãos e sistemas se comportariam como subalternos obedientes; e os nervos se assemelhariam a linhas telegráficas. Esse modelo também conferiria ao cérebro a tarefa de gerar "todos os impulsos" que colocariam os “órgãos em movimento" (REICH, 1949/1973c, p. 116-117, tradução nossa; Cf. também REICH, 1943/1946b).

De acordo com a historiadora da ciência Laura Otis (2004), metáforas que atribuíam ao cérebro a função de comando geral vinham circulando desde o século XVIII, como se pode observar, por exemplo, nos “Éléments de physiologie" (Elementos de fisiologia), conjunto de escritos que o filósofo e escritor Denis

\footnotetext{
${ }^{24}$ Nesses pioneiros estudos sobre as estruturas biológicas envolvidas nos processos sensoriais e cognitivos, desempenhou importante papel o fisiologista Marie-Jean-Pierre Flourens (1794-1867), que pautou suas pesquisas por precisas remoções cirúrgicas, em animais, de diferentes áreas cerebrais. Em obra publicada em 1824, Flourens, descrevendo seus experimentos com pombos submetidos à retirada de ambos os lobos cerebrais, comentou que, embora o animal, após a cirurgia, se sustentasse muito bem em posição ereta, voasse caso fosse lançado ao ar, locomovesse-se quando empurrado e conservasse a motilidade das íris de ambos os olhos, a ave, contudo, "não enxergava", "não ouvia", "nunca se movia espontaneamente" e quase sempre assumia "o ar de um animal dormente ou sonolento" (FLOURENS, 1824, p. 30, tradução nossa). Após as ablações, ele notou que a volição, a memória e as capacidades perceptivas daqueles animais restavam bastante comprometidas. Flourens também defendeu a tese de que o cérebro funcionaria de forma unitária, não como "um mosaico de capacidades discretas" (WEIDMAN, 1999, p. 5, tradução nossa).
} 
Diderot (1713-1784) produziu entre 1774 e 1780. Ecoando certo conhecimento científico da época, Diderot avaliou que "tudo corre bem" quando o cérebro comanda os nervos e estes se mantêm na condição de "escravos"; mas, ponderou o pensador francês, tudo desanda quando os nervos se rebelam, tornando-se “ministros” ou, até mesmo, “déspotas” (DIDEROT, 1996, p. 318, tradução nossa) do cérebro. Esse gênero de metáfora politicamente retrógrada teria mantido certa presença no século XIX e, como afirmam dois comentadores, alguns estudiosos continuaram caracterizando o sistema nervoso como o mais “"nobre”" ou “"o maioral”" (CLARKE; JACYNA, 1987, p. 5-6, tradução nossa) entre os sistemas corporais.

Na segunda metade do século XIX também ganharam força as analogias entre o aparato nervoso e o sistema telegráfico, tendo sido empregadas por um grande número de autores (OTIS, 2004). ${ }^{25}$ O filósofo escocês Alexander Bain (18181903), por exemplo, ponderou em 1885, no livro The Senses and the Intellect, que o cérebro funcionaria como uma estação central da qual partiriam ramificações para diversas subestações: “o fio telegráfico apresenta grande semelhança com um nervo que segue do cérebro em direção a qualquer parte do corpo". A "substância cinza dos centros nervosos" teria, inclusive, grande semelhança com "uma bateria voltaica em que a força elétrica é gerada pela corrosiva força de um ácido” (BAIN, 1855, p. 57, tradução nossa).

Opondo-se à concepção que apregoava um “centro 'superior”” e um “órgão executor 'inferior'”, Reich preferia pensar o ser humano como uma harmoniosa

\footnotetext{
${ }^{25}$ Laura Otis (2004) esclarece que, desde a época em que os cientistas começaram a estudar o sistema nervoso, ele foi descrito a partir de metáforas tecnológicas: sistema hidráulico (séculos XVII e XVIII), rede telegráfica (século XIX), rede cibernética (século XX). Para a pesquisadora norte-americana, as analogias mais contemporâneas entre cérebros e computadores teriam raízes históricas diretas nas comparações que os fisiologistas do século XIX estabeleceram entre o sistema nervoso e o telégrafo.
} 
"cooperativa natural de órgãos equivalentes", os quais, apesar de suas diferenças, integrar-se-iam no conjunto corporal. Ainda que participando ativamente da coletividade corpórea, cada órgão apresentaria grande autonomia, manifestando uma "linguagem expressiva" própria que não seria determinada por qualquer ““centro no sistema nervoso'” (REICH, 1949/1973c, p. 116-117, tradução nossa).

Reich não foi o único, porém, a criticar a tese do centralismo cerebral; na verdade, tal questionamento antecede a produção reichiana. Exemplo disso são os incisivos questionamentos que o eminente médico, patologista e político alemão Rudolf L. K. Virchow (1821-1902) dirigiu, como veremos brevemente a seguir, ao conceito de um centro biológico unificador e privilegiado. ${ }^{26}$

Professando teses vitalistas, mas não espiritualistas (FELTZ, 1995; BENAROYO, 1997), Virchow afirmou em 1849 que a "física e química dos processos vitais" não estariam aptas para explicar, por si sós, o "núcleo mais íntimo da vida" e o "princípio imanente que a anima" (VIRCHOW, 1849, citado em BENAROYO, 1997, p. 457-458, tradução nossa). Seria necessário reconhecer, de acordo com o patologista alemão, que o organismo se encontra sob efeito de duas forças distintas, as Molecularkràfte (forças moleculares) e a Lebenskraft (força vital). 0 autor ponderou em 1856 que essa Lebenskraft estaria "na origem da vida" e seria parte integrante dela, "propagando-se de uma substância a outra e produzindo, assim, uma sequência de movimentos cuja essência é a própria vida" (VIRCHOW, 1856, citado em BENAROYO, 1997, p. 457, tradução nossa). No entanto, a questão "do impulso original, da Criação" sempre teria, na visão virchowniana, uma

\footnotetext{
${ }^{26}$ Não localizamos menções reichianas às obras do patologista, mas é provável que o jovem Reich as tenha estudado quando cursava medicina ou que as tenha conhecido por meio da Geschichte des Materialismus de Lange, obra que marcou sua produção, como veremos em outro momento.
} 
conotação "transcendental”, por conduzir a um terreno que não ofereceria qualquer apreensão experiencial ou possibilidade “de contemplação ou entendimento imediato" (VIRCHOW, 1849, citado em BENAROYO, 1997, p. 457-458, tradução nossa).

A teoria do centralismo cerebral também foi amplamente criticada por Virchow, como se pode observar em um de seus trabalhos mais conhecidos - Die Cellularpathologie in ihrer Begründung auf physiologische und pathologische Gewebelehre (“A patologia celular fundamentada no estudo fisiológico e patológico dos tecidos”) -, publicado em 1858. ${ }^{27}$ Para o patologista, as discussões acerca do funcionamento da vida deveriam partir, não da tese de que haveria um "ponto anatômico central” responsável por “todas as ações do organismo”, mas sim, da existência de "pequenos centros" em todas as partes do corpo:

É fácil afirmar que o sistema nervoso representa a verdadeira unidade no corpo humano, visto que não existe outro sistema tão amplamente difundido em todas as partes periféricas e nos mais diversos órgãos. Mas esta vasta extensão em si mesma, essas formas de união tão variadas que conectam as diversas partes do sistema nervoso estão longe de representá-lo como centro de todas as funções orgânicas. [...] os defensores [da tese de que o aparato nervoso é o centro de todos os fenômenos da vida] não poderiam encontrar em nenhum ponto do sistema nervoso o ponto central soberano, aquele que rege todas as outras partes do corpo (VIRCHOW, 1858/1868, p. 247-248, tradução nossa).

Esse centralismo anatomofisiológico seria produto, no entendimento virchowniano, de uma ilusão subjetiva de unidade. Produto de uma consciência que conceberia a si própria como centro soberano (retomaremos essa proposição logo abaixo), a teoria de um ponto central não permitiria olhar o organismo como uma

\footnotetext{
${ }^{27}$ Valemos-nos aqui de uma tradução da obra para a língua francesa: La pathologie cellulaire basée sur l'étude physiologique e pathologique des tissus (VIRCHOW, 1858/1868).
} 
vasta sociedade composta de criaturas vivas dotadas de grande autonomia: as células. Para Virchow, que desenvolveu estudos pioneiros no campo da patologia celular, propondo que as raízes dos processos patológicos deveriam ser procuradas no domínio das células, não diretamente em órgãos ou tecidos, o organismo seria uma espécie de sociedade ou república formada por uma pluralidade de entidades protoplasmáticas vitais (VIRCHOW, 1858/1868).

A concepção de um centro irradiador soberano na criatura humana seria, aliás, bem mais antiga do que as pesquisas sobre o sistema nervoso e remeteria à própria noção de consciência. Avessa, ela também, à pluralidade, a ideia de consciência remontaria, como analisa uma filósofa que examinou os escritos de Virchow, "à filosofia do Ego, aquela que, com Descartes e Kant, começa com o Eu" (STIEGLER, 2001, p. 23, tradução nossa).

Com a teoria celular, teria chegado o momento de compreender, segundo o patologista, “que o ‘Eu’ dos filósofos” (o Eu sintético, soberano, central) nada mais seria do que "uma consequência do 'Nós' dos biólogos” (VIRCHOW, 1859, citado em STIEGLER, 2001, p. 23, tradução nossa) ou, em outras palavras, da multiplicidade protoplasmática celular. Pois esse “Nós” ou coletividade de seres vivos, além de apresentar razoável autonomia, antecederia filogeneticamente a existência do sistema nervoso, da consciência humana ou de quaisquer outras "figuras tradicionais de centralização” (STIEGLER, 2001, p. 22, tradução nossa).

A tese de que o leme ou instância unificadora da existência não deveria ser procurada diretamente no Eu, na consciência ou no aparato nervoso, mas na multiplicidade do "Nós" celular, também foi amplamente reelaborada por Nietzsche, pensador que sofreu forte influência da produção virchowniana 
(STIEGLER, 2001). ${ }^{28}$ Em La gaya scienza (“A gaia ciência”), originalmente publicada em 1882, ele apresentou com clareza suas críticas ao exagerado poder centralizador que, a seu ver, vinha sendo atribuído à consciência. Frequentemente representada como "âmago do ser humano", a consciência parecia apontar para aquilo que, no indivíduo, seria "duradouro, derradeiro, eterno, primordial”. No entanto, talvez fosse mais adequado considerá-la, ponderou o pensador, como o "último e derradeiro desenvolvimento do orgânico" e, consequentemente, como aquilo que no indivíduo seria "mais inacabado e menos forte" (NIETZSCHE, 2001, p. $62)$.

Muito mais surpreendente e sofisticado do que essa incipiente consciência escreveu Nietzsche em 1885 em seu caderno de notas - seria "o corpo vivo": "esta vasta coletividade de seres vivos", "estes minúsculos seres vivos que constituem nosso corpo" (NIETZSCHE, citado em STIEGLER, 2001, p. 24, tradução nossa). Ao criticar o caráter, a seu ver, orgulhoso e prepotente da consciência, o filósofo alemão ecoava as formulações de Virchow de que "cada animal" seria o somatório de "unidades vitais" (as células) que carregariam, em si mesmas, "as características completas da vida"; de que a marca distintiva da "unidade da vida" não se localizaria em um "ponto limitado de uma organização superior”, como, por exemplo, no cérebro; de que o indivíduo seria constituído por uma "massa de existências individuais, dependentes umas das outras", cada uma delas dotada, porém, de "atividade própria" (VIRCHOW, 1858/1868, p. 15-16, tradução nossa). ${ }^{29}$

\footnotetext{
${ }^{28}$ Reich apontou Nietzsche como uma das principais influências em sua obra (REICH, 1949/1973c) e comentou que retornava "a Nietzsche repetidamente", "esse homem de vasto conhecimento e grande sofrimento” (REICH, 1999, p. 432, tradução nossa).

${ }^{29}$ Lange $(1865 / 1950)$ destacou a influência, no trabalho de Virchow, de certas proposições do filósofo, cientista e escritor Johann Wolfgang von Goethe (1749-1832). Parece-nos que a inspiração goethiana também se fez presente, de alguma forma, na pesquisa de Reich, embora esse tema não tenha sido
} 
Reich, além de se associar aos críticos do centralismo cerebral, também questionou, como havíamos mencionado há pouco, o conceito de que o cérebro seria o gerador dos “impulsos” que colocariam "os órgãos em movimento" (REICH, 1949/1973c, p. 116-117, tradução nossa). Como explicam dois comentadores, de fato é possível identificar, desde o século XIX, teorias que concebiam o cérebro como gerador de eletricidade ou de uma "força nervosa" (CLARKE; JACYNA, 1987, p. 180, tradução nossa) aparentada à energia elétrica. O célebre cientista inglês Frederick W. Herschel (1792-1871), por exemplo, pautando-se por "numerosos e decisivos experimentos" acerca da ação da eletricidade nos músculos, sentia-se convicto de que o cérebro - "órgão maravilhosamente constituído" - seria a fonte da “força elétrica” (HERSCHEL, 1831/1840, p. 342-343, tradução nossa). Herschel explicou que o cérebro, comportando-se como uma espécie de pilha elétrica, se descarregaria a si próprio em intervalos regulares, mediante, por exemplo, certos nervos que se comunicariam com o coração e promoveriam, assim, a pulsação cardíaca.

Como vimos em outro momento, Reich mostrou simpatia, desde o início de sua carreira, pela asserção de que o organismo vivo seria movido por uma força biológica especial (distinta, por exemplo, da energia elétrica ou térmica). Julgando ter objetivado cientificamente, em 1939-1940, essa força primordial, o autor se referiu, em sua fase madura, a um "impulso motor interno" que derivaria diretamente daquela energia básica. Parecia-lhe, até mesmo, que a Biologia deveria dedicar especial atenção à fonte desses “impulsos internos do organismo

avaliado, até onde temos conhecimento, por comentadores reichianos. Goethe, que antecedeu os autores da geração de Virchow, ponderou, como se observa em um escrito científico de 1807, que seria mais apropriado conceber o organismo como uma coletividade de criaturas dotadas de ampla autonomia ou, nas palavras do ilustre pensador, uma "reunião de seres que vivem e existem por si mesmos" (GOETHE, 1837 , p. 16 , tradução nossa). 
vivo”, pois o cientista não tinha dúvidas de que o que diferenciaria a matéria viva da matéria não viva seria o fato de a primeira produzir internamente e coordenar, de alguma forma, seus próprios “impulsos motores” (REICH, 1948/1973e, p. 29, tradução nossa).

Em mais de uma oportunidade o cientista insistiu que as células nervosas não produziriam “impulsos”, e que sua função seria essencialmente a de transmiti-los (REICH, 1949/1973c, p. 116-117, tradução nossa). Seria necessário, a seu ver, abandonar a "concepção mecanicista do cérebro" e passar a considerar este órgão tão somente como um “'transmissor' especial das funções plasmáticas globais, não como a fonte dos impulsos motores" (REICH, 1949/1973h, p. 455, tradução nossa, grifos do autor). ${ }^{30}$

De acordo com as pesquisas realizadas pelo cientista, essa fonte dos impulsos deveria ser buscada, muito mais, nos "plexos ganglionares do sistema nervoso autônomo" (REICH, 1934/1982a, tradução nossa, grifo do autor). No decorrer de sua obra, Reich dedicou grande atenção ao sistema nervoso autônomo, pois esse sistema, além de atuar como gerador dos impulsos plasmáticos, estaria associado a certas matrizes da sensorialidade humana. Assim, cabe examinar, brevemente, alguns estudos do autor sobre o tema.

\subsubsection{Anterioridade filogenética da função vegetativa}

Comentamos anteriormente que Reich procurou conhecer em profundidade, desde o início de sua produção, o funcionamento do aparato nervoso. No decorrer

\footnotetext{
${ }^{30}$ Nietzsche também ponderou, em 1884, que o aparato nervoso e o cérebro constituíam tão somente "um sistema condutor" (NIETZSCHE, 1884, citado em BORDENAL, 2010, p. 233, tradução nossa).
} 
desses estudos, ele se sentiu especialmente atraído por certos fenômenos somáticos humanos que se apresentam de forma involuntária e, em grande medida, independentes da vontade consciente (como o batimento cardíaco e os processos de regulação da temperatura corporal), e procurou estudar com afinco seu aparato coordenador: o sistema nervoso autônomo ou vegetativo. Frequentemente empregando, para se referir de forma genérica a essas operações autônomas, a expressão “função vegetativa” (REICH, 1934/1982a, p. 56, tradução nossa), o autor indagou se essa complexa função (ou sistema) tomaria raízes em outra, filogeneticamente mais primitiva e que, talvez, se fizesse presente mesmo em criaturas desprovidas de sistema nervoso (tais como os organismos unicelulares e certos multicelulares). Empreendendo uma ampla revisão da literatura técnica (e, posteriormente, valendo-se de seus próprios experimentos bioelétricos e microbiológicos), Reich encontrou uma resposta positiva para sua pergunta. A seu ver, a atividade vegetativa humana nada mais seria do que uma especialização de certas operações presentes em organismos sem sistema nervoso, como as operações de “movimento plasmático, hidratação e desidratação, contração e expansão, tensão e relaxamento" (p. 58, tradução nossa, grifo do autor).

Dessas operações ou funções, o autor realçou o fenômeno da pulsatilidade: “Podemos visualizar a função de contração e expansão da substância vegetativa em moluscos, vermes, caracóis, assim como, no plasma da ameba" (REICH, 1937/1982b, p. 124, tradução nossa, grifos do autor). No ser humano, tal pulsatilidade alcançaria, ainda que com diferentes ritmos, "todos os órgãos, inclusive os nervos, vasos, vias linfáticas e células dos tecidos" (REICH, 1948/1973e, p. 359, tradução nossa). 
Por acreditar que a pulsatilidade plasmática se manifestaria tanto em seres unicelulares, quanto em organismos multicelulares (providos ou não de sistema nervoso), o autor empregava o termo "vegetativo" até mesmo para se referir ao funcionamento de certos micro-organismos: "A subestrutura do sistema de atividade vital da ameba nada mais é do que um fluxo vegetativo de plasma" (REICH, 1934/1982a, p. 43, tradução nossa, grifo do autor).

Dessa linha de raciocínio resultou um pressuposto central da produção reichiana: o de que a "função vegetativa" (a pulsatilidade protoplasmática) seria "filogeneticamente mais antiga do que a função cerebral". O fato de essa espontânea contratilidade plasmática ocorrer mesmo em primitivos seres unicelulares sem sistema nervoso, demonstraria inequivocamente, na visão reichiana, que a vida, do ponto de vista filogenético, pôde se efetivar “muito antes de um cérebro se desenvolver” (REICH, 1937/1982b, p. 121, tradução nossa, grifos do autor).

Para o autor, a função vegetativa humana nada mais seria do que uma extensão ou complexificação daquela primitiva pulsatilidade plasmática. Sob essa perspectiva, o cérebro deveria ser visto como um órgão “especialmente projetado para implementar e inibir as funções corporais vegetativas globais" (REICH, 1937/1982b, p. 121, tradução nossa, grifos do autor), como um direcionador dos diversos processos associados aos movimentos plasmáticos gerais de expansão e contração. ${ }^{31}$

\footnotetext{
${ }^{31}$ O fisiologista Ludwig R. Müller (1870-1962), um dos pioneiros na pesquisa sobre o sistema nervoso autônomo, parece ter exercido importante influência na obra reichiana. Em sua autobiografia científica de 1942, Reich lembrou que o fisiologista, em obra publicada em 1931 - Lebensnerven und Lebenstriebe -, indicou as bases vegetativas de algumas doenças, categorizando, por exemplo, certas formas de anemia como "enfermidades simpaticotônicas" (REICH, 1942/1989, p. 365, tradução nossa). Essa e outras menções indicam que as investigações reichianas sobre o papel do sistema vegetativo no bem-estar e em certas condições patológicas humanas foram certamente alimentadas por trabalhos do fisiologista,
} 
Apoiando-se na teoria protoplasmática e em seus próprios experimentos laboratoriais, o cientista ponderou que era incorreto conceber a estrutura vegetativa como praticamente imóvel. Em sua opinião, tal estrutura manifestaria amplo movimento espontâneo, comportando-se literalmente "como uma massa de plasma que expande e contrai": "O sistema nervoso vegetativo é [...] um sistema plasmático contrátil, um órgão contrátil que permeia todo o organismo”. Atuando como alinhavadora e moduladora do conteúdo plasmático do organismo como um todo, a função vegetativa, dada sua anterioridade filogenética, representaria a base da coesão organísmica ou, nas palavras do autor, da "uniformidade da função corporal global” (REICH, 1937/1982b, p. 125, tradução nossa, grifo do autor). 0 autor insistiu, ainda, que caberia à função vegetativa o papel de "gerador" ou “produtor” (REICH, 1934/1982a, tradução nossa, grifos do autor) dos impulsos plasmáticos. $^{32}$

embora essa influência ainda não tenha sido, até onde temos conhecimento, abordada por comentadores reichianos.

${ }^{32}$ Reich procurou apresentar, em diversos escritos técnicos, as provas experimentais de sua tese de que o
sistema nervoso autônomo atuaria como uma espécie de usina energética. Foge de nossos propósitos
avaliar tais comprovações e outras formulações reichianas acerca do sistema nervoso autônomo.
Destacaremos brevemente, porém, algumas conclusões gerais a que chegou o autor. Inicialmente, cabe
mencionar que o cientista identificou uma identidade entre o núcleo da célula e a função vegetativa: “O
núcleo deve ser considerado como o 'centro vegetativo' da célula individual, da mesma forma que o
sistema nervoso autônomo constitui o 'núcleo biológico' ou 'centro vegetativo' do organismo como um
todo". Ambas as estruturas seriam, na visão reichiana, dotadas de altíssimo potencial energético: "O
núcleo celular e o sistema nervoso autônomo representam os aparatos energéticos mais concentrados e
substanciais em seus respectivos sistemas orgonóticos" (REICH, 1948/1973e, p. 224, tradução nossa).
Além disso, Reich, pautando-se pelas operações "bioenergéticas" de expansão e contração, procurou
integrar em um quadro geral diversos aspectos das funções autônomas, correlacionando-as: (a) aos
movimentos biofísicos de "ir em direção ao mundo" (estiramento-expansão) e "retirar-se do mundo"
(encolhimento-contração), (b) à ação de certos componentes bioquímicos (tais como potássio e cálcio) e
(c) aos estados de prazer e angústia (REICH, 1934/1982a, 1934/1982c, 1937/1982b, 1942/1989). Nessa
tentativa de reduzir as “inervações autônomas às funções biológicas básicas de expansão e contração do
organismo total", o autor concluiu que "o sistema nervoso parassimpático sempre estimula os órgãos
quando - seja para torná-los tensos, seja para eliciar um relaxamento - o organismo como um todo se
encontra em estado de expansão prazerosa. Por outro lado, o sistema nervoso simpático estimula todos
os órgãos [...] quando o organismo como um todo se encontra em estado de contração angustiosa. Isso
nos permite compreender a atividade da vida, particularmente a respiração, como um estado de
oscilação contínua, no qual o organismo está continuamente alternando entre a expansão parassimpática 
No entendimento do cientista, a função vegetativa do animal protoplasmático humano não seria, porém, modulada apenas por primitivos fatores filogenéticos; a esfera sociocultural também desempenharia, a seu ver, importante papel.

\subsubsection{Vitalidade vegetativa e dimensão sócio-histórica}

Em 1934, Reich proferiu, no $13^{\circ}$ Congresso Internacional de Psicanálise, realizado em Lucerne, uma conferência intitulada "Psychischer Kontakt und vegetative Strömung” (Contato psíquico e corrente vegetativa). Foi sua última apresentação no âmbito da Associação Psicanalítica, pois, durante o evento, ele foi informado de sua expulsão da agremiação.

Publicando o conteúdo de sua conferência em $1935,{ }^{33}$ o autor, entre diversos outros temas, abordou a relação que se estabeleceria entre a função vegetativa humana (a pulsatilidade plasmática) e as determinações socioculturais. Dado que Reich coligou, como notaremos mais adiante, a sensorialidade humana ao estado de movimento da função vegetativa, cabe resgatar brevemente o papel que, a seu ver, a esfera social desempenharia nessa motilidade plasmático-vegetativa.

Acreditando que a função vegetativa apresentaria um amplo potencial energético de transformação, tanto emocional, quanto intelectual, Reich ponderou que essa força biológica (ou bioenergética) poderia se exercer vigorosamente na construção de organizações sociais democráticas e solidárias. Esse vasto potencial

(exalação) e a contração simpática (inalação)" (REICH, 1942/1989, p. 295, tradução nossa, grifos do autor).

${ }^{33}$ Valemo-nos aqui de uma tradução do material para a língua inglesa: "Psychic contact and vegetative current" (REICH, 1935/1973d). 
representaria, no entanto, grande perigo para as sociedades autoritárias, que tenderiam a sufocá-lo, valendo-se dos mais variados mecanismos.

Um desses mecanismos residiria na tentativa, das tiranias políticas, de caracterizar negativamente a "vida vegetativa" como "primitiva e animal", para então a contrapor a uma "vida substitutiva 'cultural"”, esta retratada como “diferenciada e altamente desenvolvida” (REICH, 1935/1973d, p. 326, tradução nossa). Esses valores aparentemente diferenciados seriam substitutivos porque, na visão do autor, conteriam na verdade um ideário autoritário que em nada colaboraria para a expansão ou "continuidade da vida vegetativa" e só faria afastar o indivíduo de sua vitalidade corporal. Parecia-lhe, inclusive, que essas "formações vegetativas substitutivas" não haviam dado qualquer contribuição para o desenvolvimento humano, o qual, a seu ver, teria tido como fonte tão somente o “contato vegetativo direto" dos indivíduos com o mundo. Seria desolador, na visão reichiana, o destino da organização social totalitária: ela acabaria se tornando “congelada em formas e fórmulas rígidas" e “infrutífera como uma planta seca” (p. 327, tradução nossa).

A "vida vegetativa", por sua vez, seria "intrinsecamente produtiva e dotada de infinitas possibilidades de desenvolvimento", pois sua "energia" não estaria “cronicamente congelada e limitada". Um considerável potencial energético poderia vir à tona, na avaliação do cientista, caso fosse possível “libertar as estruturas humanas de suas funções substitutivas e restaurar a imediaticidade de sua relação com a natureza e a sociedade”. Para o cientista, essa desformatação das forças vegetativas não teria como resultar, "felizmente”, em uma "nova religião”, como “um novo movimento de ioga” que passasse a pregar "“a função do contato direto"”. Pois uma profunda modificação na estrutura humana pressuporia 
significativas "mudanças no sistema social, incompreensíveis para os estudantes de ioga” (REICH, 1935/1973d, p. 327, tradução nossa). ${ }^{34}$

Otimista, como se nota na citação acima, em relação às potencialidades humanas (mas certamente pecando pela generalização em seus comentários sobre os praticantes da ioga), o autor, entretanto, considerava que a força vegetativa da maior parte da humanidade estaria "cronicamente congelada e limitada" (REICH, 1935/1973d, tradução nossa, p. 327). Esse arrefecimento das potencialidades plasmático-vegetativas assentar-se-ia, segundo o cientista, no fenômeno do encouraçamento.

\subsection{Couraça humana}

Temos feito várias baldeações, por assim dizer, em nosso trajeto em direção ao tema da sensorialidade no trabalho de Reich. Começamos historiando a teoria protoplasmática e vimo-nos na necessidade, também, de retomar rapidamente certas formulações que o cientista endereçou ao campo da energia. Quando rastreamos o entendimento reichiano acerca do protoplasma, notamos que o autor não apenas interpretou o assunto a partir de sua plataforma energética, como também caracterizou (ao criticar aspectos da neurologia de sua época) a função vegetativa humana como um sistema organizador de toda a massa plasmática corporal. Logo acima, pudemos perceber que Reich depositou grandes esperanças na liberação das forças plasmático-vegetativas (que representariam, a seu ver, um

\footnotetext{
${ }^{34}$ Ao retomarmos esse pareamento reichiano entre a função vegetativa e as modelações culturais, quisemos realçar que o autor não se limitou ao aspecto biológico da questão, mas que considerou, também, as determinações sociais. No entanto, vai além de nossos intentos examinar as propostas concretas de Reich para uma transformação social que valorizasse as potencialidades vegetativas humanas. Uma visão geral acerca dessas propostas, as quais, aliás, assumiram diferentes roupagens ao longo do trabalho do cientista, podem ser encontradas em Reich (1933, 1946c, 1976b).
} 
vasto manancial energético), sublinhando, porém, que as sociedades autoritárias tenderiam a engessar tais forças.

Abordaremos, agora, o fenômeno que, no entendimento do autor, daria expressão àquele engessamento ou limitação do potencial plasmático-vegetativo: o encouraçamento. Pois foi durante seu trabalho clínico, ao tentar lidar com o “encouraçamento cronicamente rígido” ( $\mathrm{REICH}, 1990 \mathrm{a}$, p. 76, grifo do autor) de seus pacientes, que o cientista começou a definir o importante conceito, em sua obra, de sensações plasmáticas ou sensações de órgão.

\subsubsection{Encouraçamento caracterial}

Uma das principais preocupações de Reich ao longo de quase toda a sua produção, residiu em compreender como se formariam os mecanismos defensivos à “motilidade vegetativa livre” (REICH, 1935/1973d, p. 314, tradução nossa) e decifrar as razões sociais desse amortecimento dos "impulsos vegetativos" (REICH, 1942/1989, p. 332, tradução nossa). Para designar o mecanismo associado a essa paralisia da “energia vegetativa” (REICH, 1935/1973d, p. 294, tradução nossa), ele empregou, desde o início de sua carreira, os termos charakterliche Panzer (couraça do caráter) e Panzerung (encouraçamento), além de outros, correlatos (REICH, 1933/1969).

Ao que tudo indica, o autor se referiu à couraça pela primeira vez em um artigo publicado em 1922 - “Zwei narzißtische Typen” (Dois tipos narcisistas) -, quando, no primeiro estágio de sua obra, trabalhava como psicanalista em Viena. No texto em apreço ele fez menções à “couraça narcísica” (REICH, 1922/1976a, p. 147, tradução nossa), designando com essa expressão as tenazes resistências que 
determinados pacientes impunham ao trabalho terapêutico. Em 1927, em uma apresentação intitulada "Zur Technik der Charakteranalyse" (Sobre a técnica da Análise do Caráter), posteriormente integrada ao livro Charakteranalyse - Technik und Grundlagen für studierende und praktizierende Analytiker ("Análise do Caráter - Técnica e fundamentos para estudantes e analistas praticantes”), ele se referiu ao Charakterliche Panzerung (encouraçamento caracterial) como um “mecanismo de defesa compacto" que alcançaria desde "estímulos provenientes do mundo exterior” até a dinâmica da “libido” (REICH, 1933/1969, p. 62, tradução nossa). Essa couraça caracterológica - também denominada pelo autor, em seu período psicanalítico, de couraça narcísica ou couraça do Eu (Ich) - atuaria como um arraigado, automatizado e exaustivo sistema de proteção ao contato do indivíduo com conteúdos psíquicos que, embora fundamentais para a integridade psicológica, seriam por demais angustiantes ou de difícil metabolização (REICH, 1933/1969).

Ao impedir o contato com certa gama de sentimentos desprazerosos, a couraça privaria o indivíduo de relevantes (ainda que dolorosas) experiências, assim produzindo uma grave limitação de sua flexibilidade ou "mobilidade psíquica” (REICH, 1933/1969, p. 253, tradução nossa); em outras palavras, o amortecimento se expandiria e, não se restringindo aos conteúdos psíquicos desconfortáveis, acabaria minando, também, a percepção do prazer.

O cientista insistiu, porém, que a couraça não deveria ser vista como um mecanismo estático, posto que em situações pouco agradáveis ela se acentuaria e em situações prazerosas se suavizaria, como se os "interesses libidinais e de outros gêneros", comportando-se à maneira de pseudópodos amebóides, se lançassem em direção ao mundo ou se retraíssem. A diferença entre a estrutura de caráter 
“orientada em direção à realidade" (realitätstüchtiger) e a estrutura de caráter "neurótica" residiria, justamente, no "grau de mobilidade do caráter" (REICH, 1933/1969, p. 166-167, tradução nossa). A primeira estrutura conseguiria, diante de situações difíceis ou desprazerosas, fechar-se (protegendo-se) e, depois, voltar a se abrir (flexibilizando as defesas), ao passo que o sujeito neurótico apresentaria, continuamente, um endurecimento caracterial crônico. A couraça, no entanto, não seria um acidente ou acontecimento fortuito; ela teria, como indicou o autor em seu Charakteranalyse, origem social:

\begin{abstract}
A couraça de caráter se desenvolve como resultado crônico do conflito entre as exigências dos impulsos (Triebansprüchen) e as frustrações que o mundo exterior impõe àquelas exigências; sua força e razão de ser nascem do conflito atual entre o impulso (Trieb) e o mundo exterior. A expressão e a soma destas imposições exteriores na vida dos impulsos (Triebleben) [...] formam uma unidade histórica. Isso se torna imediatamente evidente quando pensamos em conhecidos tipos de caráter, tais como o 'burguês', o 'funcionário', o 'proletário', o 'açougueiro' etc. O lugar em que se forma a couraça é o Eu (Ich), precisamente aquela parte da personalidade que se situa na fronteira entre a dinâmica dos impulsos (Triebhaften) biofisiológicos e o mundo exterior (REICH, 1933/1969, p. 167, tradução nossa).
\end{abstract}

Em seus escritos orgonômicos o autor continuou indicando as causas sociais da couraça. Em Cosmic Superimposition ("Superposição Cósmica”), Reich ponderou que seriam, essencialmente, as influências socioeconômicas - encarnadas na “estrutura familiar" e na "religião mística", entre outras instâncias - que reproduziriam a couraça "em cada geração de recém-nascidos". Afetados por normas autoritárias desde a infância, os indivíduos encouraçados acabariam 
forçando "seus próprios filhos a se encouraçarem" (REICH, 1951/1973b, p. 288, tradução nossa). ${ }^{35}$

Os estudos de Reich sobre o fenômeno do encouraçamento o levaram a estabelecer, no período 1928-1934, uma formulação que se tornou central em sua obra, norteando todas as suas pesquisas clínicas, sociológicas e laboratoriais. Tratase da diferenciação entre “impulsos primários” e “impulsos secundários”. Em diversas oportunidades, o cientista salientou que os impulsos primários diriam respeito aos "desejos e necessidades genitais naturais, socialmente fecundos", ao passo que os secundários remeteriam aos "impulsos perversos, frustrados, cruéis, obscenos, infecundos” (REICH, 1953/1975c, p. 97, tradução nossa). Para o autor, os impulsos secundários não seriam próprios da natureza humana, mas passariam a fazer parte dela quando o sujeito sofre (em culturas autoritárias) uma massiva supressão social de seus ímpetos primários (REICH, 1945/1973f); a repressão social incorporar-se-ia, então, à estrutura caracterial do indivíduo, assumindo a função moralística inicialmente desempenhada pela sociedade. 0 autor também salientou que os impulsos primários gerariam “um 'sentimento de satisfação', isto é, uma

\footnotetext{
${ }^{35}$ Em Cosmic Superimposition, Reich, sem negar a influência das ideologias autoritárias na formação da couraça, cogitou sobre outro fator, bastante primitivo, que poderia ter dado origem ao processo de encouraçamento. Tal hipótese deveria ser tomada, segundo as recomendações do autor, como algo mais do que mera especulação, "posto que fundamentada em experiência clínica recente e abundante", mas não como uma cogitação com potencial prático, por não oferecer "qualquer caminho novo para lidar com o problema". Dentro desses limites, o cientista ponderou sobre a possibilidade de a couraça humana ter surgido em tempos imemoriais - ou no "longínquo passado do desenvolvimento humano" (REICH, 1951/1973b, p. 288, tradução nossa) -, quando o "animal humano" (p. 282, tradução nossa) teria passado a raciocinar sobre suas próprias sensações vegetativas, sobre a "capacidade de perceber a si mesmo" e, inclusive, sobre a própria ação perceptiva (p. 293, tradução nossa). A experiência clínica, especialmente no trabalho com pacientes esquizofrênicos, levou o autor a suspeitar que aquela espécie de metapercepção teria gerado, por alguma razão, um profundo temor, de forma que o "ser humano", "pela primeira vez na história de sua espécie, começou a se encouraçar contra o medo e o assombro interiores" (p. 293, tradução nossa). De maneira semelhante à centopeia da fábula, que, ao começar a se deslocar, "ficou paralisada" quando começou a "pensar" a respeito de qual de suas pernas moveria em primeiro lugar, em segundo lugar e assim sucessivamente, seria bem provável, na opinião do autor, que, "ao tentar compreender a si mesmo e a corrente de sua própria energia, o ser humano interferiu nela; ao fazer isso, começou a encouraçar-se e, dessa forma, a se separar da natureza" (p. 294, tradução nossa, grifos do autor).
} 
redução objetiva no nível de energia”, enquanto os impulsos secundários não produziriam “qualquer satisfação no cerne do organismo" (REICH, 1950/1990d, p. 18, tradução nossa). O protótipo do impulso "primário”, “natural”, "socialmente efetivo" e amplamente satisfatório seria, no entendimento reichiano, a convulsão orgástico-plasmática, e o protótipo do impulso “secundário", “cruel”, “improdutivo” (REICH, 1953/1975c, p. 97, tradução nossa) seria a destrutividade sádica. ${ }^{36}$

Temerosas das capacidades críticas e do espírito transformador que brotariam das forças vegetativas, as sociedades autoritárias, em busca de dominação econômico-ideológica, se esforçariam em sufocar, na visão do autor, os ímpetos primários. Mas, como a “repressão dos impulsos biológicos primários” (REICH, 1946a, p. vii, tradução nossa) geraria uma ampla gama de sentimentos secundários, as organizações autoritárias precisariam, também, reprimir essa “camada antissocial perversa” (p. viii, tradução nossa) da estrutura de couraça. 0 resultado final desse processo seria a constituição de um terceiro nível - uma camada superficial, consubstancializada em traços de caráter modelados pela ideologia dominante e completamente distanciados do "cerne biológico" (p. vii, tradução nossa) do indivíduo. Esses traços de superfície cumpririam dupla função: por um lado, garantiriam ao indivíduo alguma aceitação nas esferas sociais afinadas com a ideologia dominante, posto que eles refletiriam e perpetuariam os valores

\footnotetext{
${ }^{36}$ Para Reich, especialmente em sua fase norte-americana, uma importante, se não uma das principais funções da cultura consistiria em proteger os impulsos por ele denominados de primários. Desse ponto de vista, a potência orgástica, acontecimento emblemático, na perspectiva reichiana, do conjunto dos impulsos primários, expressar-se-ia plenamente caso não houvesse repressões autoritárias. Mas, cabe indagar, até que ponto o indivíduo humano, tão visceralmente articulado aos seus signos culturais, pode experienciar, de forma tão direta e imediata, tais funções profundas? 0 autor teria recaído, cabe indagar também, em um instrumentalismo pragmático que, simplificando excessivamente a dinâmica cultural, tenderia a reduzi-la a facilitadora ou desfavorecedora dos impulsos primários? As proposições reichianas trazem à tona tais questionamentos e eles mereceriam, a nosso ver, análises mais aprofundadas, que extrapolam, porém, o escopo do presente trabalho.
} 
autoritários; por outro lado, barrariam, visando alguma manutenção da vida cotidiana, a irrupção dos impulsos secundários (os quais, contudo, poderiam escapar, por exemplo, na forma de sintomatologias neuróticas ou de algum tipo de crueldade social) e dos ímpetos primários. O encouraçamento apresentaria, assim, três níveis: a camada profunda ou dos impulsos primários; a camada média ou dos impulsos secundários; e a camada superficial ou dos traços de caráter (impulsos, eles também, no entendimento reichiano) validados pelo poder autoritário.

Esse processo de encouraçamento não se limitaria, porém, à esfera psíquica; ele também atingiria o terreno somático.

\subsubsection{Encouraçamento somático}

O autor comentou que, em 1929, passou a compreender, por meio de sua experiência clínica e estudos sociológicos, que o "conflito básico na doença psíquica” - “a contradição insolúvel entre o anseio de prazer e a frustração moralística do prazer" - poderia deixar profundas marcas no âmbito muscular. 0 intenso embate psíquico entre "sexualidade e moralidade" (ou, entre os impulsos primários e sua repressão social) poderia alcançar a "profundidade biológica do organismo" (a função plasmático-vegetativa), manifestando-se como uma oposição entre “a excitação agradável e o espasmo muscular” (REICH, 1942/1989, p. 259, tradução nossa, grifos do autor). ${ }^{37}$

\footnotetext{
${ }^{37}$ Cabe mencionar que a concepção reichiana de que haveria, no ser humano encouraçado, uma produção energética interna e contínua que esbarraria e seria alterada, em situações patológicas, por uma couraça literalmente construída na periferia (ou membrana) corporal foi inspirada, como o próprio Reich reconheceu, nos conceitos, apresentados por Friedrich Kraus, de pressão interna e tensão de membrana (REICH, 1942/1989).
} 
A autoritária supressão social dos impulsos primários resultaria, no plano somático, em acentuadas contrações musculares ou em uma combinação de hipertonias e hipotonias. 0 paciente portador do "típico caráter compulsivo", por exemplo, apresentaria uma "rigidez muscular geral"; em outros casos clínicos a rigidez poderia estar "pareada com uma flacidez (hipotonia)", flacidez essa que não refletiria, em absoluto, "um estado de relaxamento" (REICH, 1935/1973d, p. 341, tradução nossa).

A repressão autoritária enraizar-se-ia, mais precisamente, em configurações ou grupos musculares que, de forma automatizada, entrariam em ação para amortecer o incremento dos impulsos primários e a expressão dos secundários:

Todos os nossos pacientes relatam que, na infância, passaram por períodos em que aprenderam a suprimir seus impulsos de raiva, angústia e amor por meio de certas manobras que influenciam o funcionamento vegetativo (prender a respiração, tensionar os músculos abdominais etc.) (REICH, 1942/1989, p. 300, tradução nossa).

A esses padrões somáticos automáticos, cristalizados, defensivos, que começariam a se estruturar na infância, o autor nomeou de "couraça muscular". Assim como a couraça de caráter, a couraça muscular consumiria ou diluiria a angústia de destruição (o forte temor em relação aos próprios impulsos destrutivos) e, especialmente, a angústia orgástica (o pânico em relação à excitação orgásticoplasmática), à custa, porém, de um arrefecimento da vitalidade vegetativa: "a rigidez somática representa a parte mais essencial do processo de repressão" (REICH, 1942/1989, p. 300, tradução nossa). 
Além de enfatizar que o espasmo muscular crônico, automatizado e defensivo (ou até mesmo a arraigada hipotonia) expressaria "a faceta somática do processo de repressão e a base para sua contínua perpetuação", o autor também esclareceu, em sua autobiografia científica de 1942, que a couraça corporal não se configuraria a partir de músculos isolados, mas sim, por meio de grupos musculares que pertencem a uma "unidade funcional". Na supressão de um impulso de choro, por exemplo, não seria apenas o lábio inferior que se tornaria tenso, "mas toda a musculatura da boca e maxilar, assim como a musculatura correspondente da garganta"; a repressão alcançaria, em suma, "todos os órgãos" que se constituem como "uma unidade funcional no ato de chorar" (REICH, 1942/1989, p. 302, tradução nossa). No entendimento do autor a couraça de caráter e a couraça muscular seriam "funcionalmente idênticas" (p. 329, tradução nossa), pois, ainda que de naturezas distintas, revelar-se-iam análogas no que concerne à ação de bloquear a irrupção dos impulsos primários ou secundários.

O cientista fez questão de esclarecer, em seus textos metodológicos do período orgonômico, que a couraça, a despeito de seu rígido automatismo, não seria, em si mesma, uma formação estática, mas sim o resultado de um "equilíbrio dinâmico de forças opostas". Longe de se parecer com uma "parede de concreto", o encouraçamento se assemelharia, muito mais, a dois automóveis que, colocados frente a frente com os motores acionados, não conseguiriam se mover, por estarem "agindo um contra o outro com a mesma força" (REICH, 1950/1990d, p. 21, tradução nossa). Um impulso se oporia a outro (por exemplo, a emoção angústia se contraporia à emoção raiva), ${ }^{38}$ constituindo-se um sistema de força e contra força

\footnotetext{
${ }^{38}$ Veremos em detalhes, mais adiante, o conceito reichiano de emoção.
} 
que, a primeira vista, pareceria parado: “O encouraçamento é a única função humana conhecida que se caracteriza pela imobilidade” (REICH, 1949/1973c, p. 48, tradução nossa). A imobilidade, rigidez, endurecimento da couraça nada mais seria, assim, do que o resultado de forças contrapostas que impedem o movimento, gerando uma condição de “motilidade congelada” (REICH, 1950c, p. 59, tradução nossa).

$\mathrm{Na}$ introdução que Reich redigiu ao seu Biographical Material, publicado quatro anos antes de seu falecimento, pode-se observar a importância crucial que o conceito de couraça assumiu no conjunto de suas reflexões:

Por meio de seu encouraçamento corporal, o animal humano apartou a si mesmo de sua origem biológica e, dessa forma, apartou-se também de sua origem cósmica, desenvolvendo uma estrutura instintual que funciona essencialmente de maneira irracional. 0 resultado disso é o caos atual de nossa civilização, ao qual o ser humano apenas pode reagir com angústia e horror (ORGONE INSTITUTE PRESS, 1953, p. 2, tradução nossa).

Ainda que considerasse o encouraçamento como uma espécie de patologia epidêmica, Reich tentou encontrar meios terapêuticos e desenvolver projetos sociais que propiciassem alguma flexibilização da couraça. No âmbito clínico, a atenuação do encouraçamento vinha frequentemente acompanhada da percepção, por parte do paciente, de um gênero bastante peculiar de apreensão sensorial: as 'sensações plasmáticas'. 39

39 Reich elaborou três abordagens clínico-terapêuticas. Quando ainda participava do movimento psicanalítico, o autor desenvolveu, entre 1925 e 1933, sua primeira metodologia clínica, um conjunto de procedimentos denominado Análise do Caráter. Partindo do pressuposto de que a estrutura de couraça seria composta por uma camada superficial (os traços de caráter rígidos), uma camada intermediária (os impulsos secundários contidos pela capa defensiva superficial) e uma camada profunda (os ímpetos 'sélficos' sufocados pelos traços de superfície e pelos impulsos secundários), Reich, por meio de seu método caractero-analítico, procurava, sobretudo, tornar consciente as principais resistências caracteriais de seus pacientes. A experiência clínica teria lhe indicado que esse processo, de sistemática 


\subsection{Sensações de corrente}

Poderemos estabelecer, agora, uma primeira aproximação com a teorização do autor sobre a sensorialidade, resgatando o conceito reichiano de sensação plasmática (esse conceito também recebeu outras denominações, como veremos adiante). Para a formulação dessa noção, o cientista contou, entre outras fontes, com a experiência advinda do trabalho terapêutico.

Ao procurar amenizar, por meio da intervenção clínica, o encouraçamento de seus pacientes, Reich teria observado a frequente irrupção de "reações no sistema nervoso autônomo" (REICH, 1942/1989, p. 299, tradução nossa, grifo do autor). Tais reações estariam diretamente associadas, no contexto do trabalho terapêutico reichiano com as defesas crônicas, à mobilização da função vegetativa e indicariam que o plasma do paciente começara a se 'descongelar' e recobrar certos fluxos ou correntes amortecidos pela couraça.

aproximação do paciente com suas defesas superficiais crônicas (os traços de caráter que funcionariam como bloqueio direto à convulsão orgástico-plasmática), propiciaria a irrupção terapêutica dos impulsos secundários (o custoso esforço neurótico, na forma da crueldade e sadismo, para acessar a camada profunda), e que esses impulsos intermediários, por sua vez, abririam gradualmente caminho, quando examinados terapeuticamente, para os ímpetos primários (consubstancializados na experiência da potência orgástica). Tendo início por volta de 1935, a segunda abordagem reichiana, a Vegetoterapia, além de levar em conta os traços caracteriais rígidos, passou a considerar, na intervenção clínica, certas atitudes somáticas cronificadas, situadas na superfície corporal, que também atuariam como mecanismos de contenção dos impulsos secundários e primários. Na esteira das pesquisas reichianas sobre a energia orgone, iniciadas em 1939-1940, surgiu a Orgonoterapia, terceira e última abordagem formulada pelo autor. A orgonoterapia continuou pautando-se pela técnica da persistente identificação das defesas (caracteriais e somáticas), mas, além de se beneficiar da experiência teórico-metodológica adquirida com as duas abordagens que a antecederam, ela pôde contar, como insistiu o autor, com um entendimento mais claro a respeito das forças orgonóticas corporais e de sua peculiar lógica de funcionamento (a pulsação orgonótica organísmica em sua dinâmica 'funcional', ou seja, não mecânica, automovente, 'espontânea'). As três abordagens, no entanto, centravam-se no trabalho sistemático com as defesas rígidas e adotavam como critério de cura o fenômeno que o autor denominou de convulsão orgástica do plasma. 
Diversas manifestações corporais decorreriam, segundo o autor, dessa flexibilização do encouraçamento, tais como "tremor involuntário e espasmos musculares", sensações de "frio e calor”, sensações de "comichão, formigamento, prurido, arrepio”, “percepções somáticas de angústia, raiva e prazer” (REICH, 1942/1989, p. 271, tradução nossa), além de certas "sensações somáticas de corrente" (p. 321, tradução nossa). Diferentemente da impressão suscitada pelas defesas automatizadas e enrijecidas, típicas da estrutura de couraça, aquele conjunto de fenômenos viria acompanhado, de acordo com os relatos reichianos, da impressão geral de movimento, mobilização ou descongelamento.

Para designar as percepções corporais que estariam intimamente relacionadas às modulações plasmático-vegetativas, Reich empregou, no transcurso de sua obra, ao menos quatro expressões: sensações plasmáticas, sensações vegetativas, sensações de órgão e sensações orgonóticas. Para compreendermos melhor esse gênero de apreensão sensorial, escolhemos um tipo de sensação plasmática (ou vegetativa, ou de órgão, ou orgonótica) a que o cientista se referiu frequentemente: as sensações de corrente. Tais sensações poderiam, de acordo com os relatos reichianos, ser percebidas no corpo como um todo, mas far-se-iam excepcionalmente vívidas na pélvis e órgãos genitais $(\mathrm{REICH}, 2012)$. Propiciando uma nítida impressão de motilidade, deslocamento, circulação e fluxo, as sensações de corrente tornaram-se, como veremos a seguir, emblemáticas para Reich e alguns de seus pacientes.

O cientista identificou as sensações de corrente, inicialmente, no âmbito clínico-terapêutico, mas não tardou a submetê-las a pesquisas experimentais. Quando teve oportunidade de associar a prática clínica ao trabalho laboratorial, na segunda metade da década de 1930, o cientista pôs-se a examinar, por meio de 
seus experimentos bioelétricos, a dinâmica daquelas sensações de corrente. Segundo os relatos reichianos, o potencial bioelétrico da pele aumentava concomitantemente à percepção (bastante consciente) das sensações prazerosas de corrente e decrescia quando o sujeito sentia dor, angústia ou outro tipo de desprazer. Em suas descrições do experimento, Reich costumava realçar que o oscilógrafo apenas indicava elevações do potencial elétrico de uma dada região corporal quando o sujeito do experimento vivenciava uma sensação de prazer (REICH, 1934/1982a, 1934/1982c, 1937/1982b).

As sensações de corrente, como mencionamos anteriormente, seriam a tradução perceptiva direta de autênticas correntes plasmáticas ou vegetativas. Reich se referiu com frequência a essa vegetative Strömung, termo originalmente cunhado por Friedrich Kraus para designar os processos de deslocamento dos fluidos corporais (SHARAF, 1983). Em sua fase orgonômica o cientista preferiu, porém, falar em corrente orgonótica (denominação que seria mais condizente com o aspecto não mecânico, automovente dos fluxos plasmáticos) e sensação orgonótica (termo que retrataria com mais precisão a apreensão psíquica da ação ou movimentação da energia orgone no sistema plasmático). A “sensação orgonótica”" designaria, assim, “a percepção subjetiva da 'excitação plasmática' objetiva” (REICH, 1945, p. 1, tradução nossa, grifo do autor). ${ }^{40}$

As sensações de corrente foram relatadas, também, por alguns pacientes que se submeteram ao método clínico reichiano da orgonoterapia. O professor universitário e psicoterapeuta Myron Sharaf (1927-1997), que estudou com Reich,

\footnotetext{
${ }^{40}$ Para o autor, a percepção, por parte de seus pacientes, de sensações físicas de correntes representaria uma prova adicional da permanência, no ser humano, de ancestrais fluxos plasmáticos observáveis em alguns organismos unicelulares. Avaliaremos essa proposição reichiana no quarto capítulo do presente estudo. Por ora, nos limitaremos a examinar como a noção de sensações de corrente nasceu da experiência clínico-terapêutica e de certa influência filosófica.
} 
foi seu paciente e escreveu uma ampla biografia sobre o autor, descreveu da seguinte maneira sua experiência com as “doces e cálidas sensações de prazer nas pernas e genitais" que costumavam se evidenciar, em seu processo orgonoterápico, após um choro intenso:

Aquilo era maravilhoso; eu jamais sentira algo semelhante. Não havia lido nada sobre o assunto e, excetuando Grethe [outra paciente de Reich e então esposa de Sharaf] e uma ou outra pessoa, nunca escutara ninguém descrever [as sensações de correntes]. Eu tinha consciência de que não compreendia muitos aspectos da produção de Reich. Várias coisas a respeito dele me deixavam intrigado e perturbado, mas havia algo que eu nunca mais colocaria em dúvida: as sensações daquelas 'correntes' (SHARAF, 1983, p. 25, tradução nossa).

Outro relato de paciente vem do ator norte-americano Orson Bean, que se submeteu a uma orgonoterapia conduzida por um discípulo de Reich, Elsworth F. Baker (1903-1985). Em livro publicado em 1971, o ator, referindo-se ao início de seu processo orgonoterápico, comentou ter vivenciado, durante uma sessão, uma “doce e difusa sensação de prazer” (BEAN, 1971/2000, p. 20, tradução nossa) que se propagava por todo seu corpo e que teria perdurado até o dia seguinte, na forma de "leves ondulações de prazer" que se deslocavam por seus "braços, pernas e tronco" (p. 28, tradução nossa).

Para Reich, as sensações de corrente representariam um importante indicador da flexibilização da couraça do paciente. Descrevendo um caso clínico, ele relatou que, com o aprofundamento do trabalho, o paciente, após ter lidado com diversas camadas de defesas, passara a sentir um incremento nas "sensações somáticas de corrente", as quais, naquele momento da terapia, estariam se manifestando nitidamente na região abdominal, nas pernas e na parte superior do 
corpo: “O paciente descrevia aquelas sensações não apenas como correntes, mas também, como voluptuosas e “doces”” (REICH, 1942/1989, p. 321-322, tradução nossa).

Mas as correntes vegetativas nem sempre seriam vivenciadas, de imediato, como percepções agradáveis, pois certo susto ou temor poderia acompanhar a reaproximação do indivíduo com seus fluxos plasmáticos espontâneos, há muito amortecidos pela estrutura de couraça. $^{41} 0$ autor sublinhou, também, que os pacientes costumavam experienciar, durante certo tempo, uma oscilação entre a irrupção das sensações vegetativas (entre elas, as de corrente) e a reinsurgência das defesas crônicas, e ele via, nessa "transição do estado de motilidade para o de rigidez" um tema central de investigação para os terapeutas que trabalhavam para “restabelecer a capacidade de corrente vegetativa” (REICH, 1935/1973d, p. 313, tradução nossa).

A mobilização das correntes vegetativas e a percepção de suas concomitantes sensações (no corpo de uma forma geral e, especialmente, nos órgãos genitais) indicariam, como mencionamos há pouco, um dos mais significativos acontecimentos do processo terapêutico reichiano. Pois, para o autor, a apreensão psíquica desses fluxos plasmáticos (sentidos, por vezes, como desagradáveis, mas tendendo a se tornarem amplamente prazerosos) daria fundamento e conduziria à potência orgástica, o principal indicador de saúde e bem-estar, na leitura reichiana.

Por conta de seu forte encouraçamento, os sujeitos neuróticos pouco ou nada saberiam, de acordo com Reich, sobre suas correntes vegetativas. Certos

\footnotetext{
${ }^{41}$ Para o autor, esse temor se expressaria, em sua forma mais intensa, como uma angústia orgástica; mais adiante, retomaremos esse conceito reichiano.
} 
indivíduos esquizofrênicos, no entanto, teriam relativa proximidade com as sensações de corrente, mas as interpretariam de forma patológica. A esse respeito, o autor se recordou, em sua autobiografia científica de 1942, de um influente estudo - “Über den Beeinflussungsapparat bei der Schizophrenie” (Da gênese do aparelho de influenciar no curso da esquizofrenia) - redigido pelo psicanalista e neurologista Viktor Tausk (1879-1919). Tausk, por quem Reich tinha grande apreço, procurou analisar, em seu ensaio, as bases psicológicas da ideia de "aparelho de influenciar", ideia essa presente em certos pacientes esquizofrênicos que se acreditavam influenciados e perseguidos por algum tipo de máquina, caixa, bateria ou outros aparatos. Tais pacientes, julgando estar sob o efeito dos imaginários instrumentos de influenciar, faziam menções a sensações de correntes elétricas que thes percorreriam todo o corpo. Experienciadas como estranhas ou não pertencentes à própria corporalidade, essas sensações de corrente eram frequentemente interpretadas, na esquizofrenia, como provenientes de forças externas ou de artefatos manipulados por um perseguidor, como relembrou Reich em The function of the orgasm:

Tausk demonstrou que o aparelho que influencia o esquizofrênico é uma projeção do próprio corpo do paciente, especialmente de seus órgãos sexuais. Apenas pude compreender corretamente isso quando descobri as excitações bioelétricas nas correntes vegetativas. Tausk tinha razão: é seu próprio corpo que o paciente esquizofrênico experiencia como perseguidor. Posso acrescentar a isso que o paciente não consegue lidar com as correntes vegetativas que o tomam. Tem de percebê-las como algo estranho, pertencentes ao mundo exterior e mal intencionadas. 0 esquizofrênico tão somente exibe, de forma caricatural, uma condição que caracteriza o homem moderno em geral. O homem moderno é estranho à sua própria natureza, ao cerne biológico do seu ser, experienciando-o como algo estranho e hostil. Tem de odiar todo aquele que tente recolocá-lo em contato com seu núcleo biológico (REICH, 1942/1989, p. 46, tradução nossa). 
Em Cosmic Superimposition o cientista voltou à questão, dando como exemplo o “processo de 'despersonalização'”. Nesse transtorno o indivíduo sentese estranho a si mesmo e/ou a realidade exterior, como vivendo um sonho ou assistindo a um filme, assumindo a posição de um distanciado observador que, sem participação ativa, vê de fora seus processos psíquicos ou corporais. Reich ponderou que, nesse estado de alheamento, o indivíduo percebe suas "correntes" não como intrínsecas ao próprio corpo, mas como um "objeto de atenção": "as sensações de corrente corporais então se manifestam, ainda que apenas de forma passageira, como estranhas, vindas de algum lugar do além" (REICH, 1951/1973b, p. 293, tradução nossa, grifo do autor). ${ }^{42}$

Cumpre ainda observar que Reich julgou ter identificado, nas análises que o filósofo francês Henri Bergson (1859-1941) dirigiu ao conceito de duração, se não uma caracterização propriamente dita das percepções corporais de corrente, ao menos uma precisa descrição do aspecto dinâmico, espontâneo (automovente, não mecânico) dessas "sensações de órgão autônomas” (REICH, 1992c, p. 62, tradução nossa).

O conceito bergsoniano de duração apontava para o fato de que a vida psicológica, ao contrário do que pudesse parecer, nada teria de descontínua. Pois a percepção de estados mentais claramente definidos e distintos não passaria, segundo Bergson, de um resíduo analítico da maneira pela qual nossa mente trata os objetos que nos rodeiam no espaço. Os sólidos, ponderou o pensador francês (BERGSON, 1889/1984a), podem ser sucessivamente decompostos e rearrumados,

\footnotetext{
${ }^{42}$ Essa projeção patológica das percepções de corrente também se faria presente, de forma mais branda, em sujeitos de 'estrutura mística', expressão cunhada por Reich para designar indivíduos que, como veremos em detalhe mais à frente, atribuiriam a esferas suprafísicas a fonte de suas sensações vegetativas.
} 
mas isso não seria válido para a vida interior. Ao afirmar que seus estados anímicos acham-se enfileirados uns ao lado dos outros, o indivíduo estaria tão somente produzindo, no entendimento do filósofo, um equivalente estático da vida interior e se coadunando com as exigências da lógica formal e da linguagem.

Nas profundas camadas da consciência ocorreria, na visão bergsoniana, uma perpétua modificação dos estados anímicos, um constante fluxo. Haveria como uma “melodia contínua da vida interior” em que os múltiplos estados não começariam nem terminariam, mas se prolongariam uns nos outros. Essa experiência da “duração" remeteria a um fluído e indivisível tempo "real” que em nada se assemelharia ao tempo abstrato e conceitual da matemática, ou ao pensamento composto por palavras que se sucedem umas às outras. As leis da mecânica e da inércia, plenamente válidas para o mundo dos objetos, jamais poderiam dar conta, segundo o pensador francês, desse dinamismo do Eu profundo. O filósofo ilustrou da seguinte maneira sua tese:

\footnotetext{
Quando o deslocamento de meu dedo ao longo de uma superfície ou de uma linha vier a suscitar em mim uma série de sensações de qualidades diversas, ocorrerá das duas uma: ou conceberei (je me figurerai) estas sensações na duração somente, mas elas suceder-seão então de tal maneira que não posso, em um dado momento, representar várias delas como simultâneas e, portanto, distintas; - ou discernirei uma ordem de sucessão, mas porque tenho então a faculdade, não somente de perceber a sucessão dos termos, mas ainda de alinhá-los conjuntamente após tê-los distinguido; em uma palavra, tenho já a ideia de espaço (BERGSON, 1889/1984a, p. 68-69, tradução nossa).
}

Ao que tudo indica, a análise bergsoniana da duração forneceu, a Reich, elementos para que ele compreendesse a maneira dinâmica, melódica, contínua pela qual as sensações de corrente apresentar-se-iam à consciência do sujeito. 
Ocorreria, na percepção das sensações plasmáticas, algo como um momentâneo arrefecimento das imposições do pensamento lógico-linear, arrefecimento bastante característico, na visão reichiana, da experiência de imersão nas sensações eróticas que se sucederiam continuamente e culminariam na experiência da convulsão orgástica. Por isso, Reich acreditava, como mencionou em carta enviada em 13 de agosto de 1943 a um cunhado seu, que as "sensações de órgão", especialmente as relacionadas à "excitação orgástica", poderiam ser de grande valia para o estudo da consciência humana; a seu ver, as mudanças de estado que ocorreriam durante a excitação sexual ofereceriam referências "claras e úteis" para o estudo do “fenômeno da consciência” (REICH, 1999, p. 194, tradução nossa). ${ }^{43}$

\subsection{Considerações gerais}

Propondo-nos a investigar as formulações que Reich endereçou ao tema da sensorialidade, vimo-nos na necessidade de ramificar nosso estudo e perscrutar alguns conceitos e posicionamentos da biologia e neurologia da segunda metade do século XIX e início do século XX.

Notamos, inicialmente, que Reich é herdeiro direto da teoria protoplasmática e que procurou reelaborá-la, especialmente no período norteamericano de seu trabalho, em termos energéticos (orgonóticos). Opondo-se tanto às concepções metafísicas, quanto às explicações estritamente físico-químicas acerca da contratilidade e plasticidade do protoplasma, o autor atribuiu esses

\footnotetext{
43 Averiguaremos, em outro momento, as conexões que o autor estabeleceu entre sensação, autopercepção e consciência.
} 
fenômenos a uma energia biológica específica que ele acreditava ter objetivado cientificamente.

Pudemos observar, na sequência, que Reich se filiou à corrente de cientistas e filósofos que questionou a ideia da soberania evolutiva do cérebro. Sem negar a importância da fisiologia cerebral, o autor chegou à conclusão que a função vegetativa (a pulsatilidade plasmática) seria filogeneticamente mais antiga do que o funcionamento cerebral. Na visão reichiana, a função vegetativa humana funcionaria, simultaneamente, como usina energética e como organizadora, em grande escala, da pulsatilidade protoplasmática das células. Dada sua ancestralidade, tal função poderia ofertar, de acordo com Reich, acessos privilegiados ao estudo dos impulsos vitais humanos (os singulares ímpetos que, na perspectiva reichiana, qualificariam o próprio fenômeno da vida).

A linha investigativa adotada por Reich o levou a tentar decifrar a dinâmica e as causas do amortecimento dos impulsos plasmático-vegetativos humanos, amortecimento esse que o cientista denominou de processo de encouraçamento. No decorrer de suas tentativas clínicas de flexibilizar o enrijecimento crônico da couraça, o autor se deparou com um conjunto de fenômenos somáticos diretamente associados à retomada da mobilidade plasmático-vegetativa. 0 descongelamento do encouraçamento seria acompanhado de correntes vegetativas que encontrariam tradução psicológica na forma de um peculiar gênero de apreensão perceptiva, ao qual o autor nomeou de sensações plasmáticas, vegetativas, orgonóticas ou de órgão.

Esse gênero de sensação, por representar um indicador psíquico privilegiado da motilidade vegetativa, passou a ocupar lugar de destaque na teorização reichiana sobre a sensorialidade. Tal teorização não foi, porém, moldada apenas 
pelas incursões do autor pelas ciências da vida. Seu contato com o campo da psicologia também se revelou essencial, como veremos no próximo capítulo. 


\section{SENSAÇÃO E EXCITAÇÃO}

"Eu sabia que se tivesse sucesso em encontrar o princípio comum de funcionamento da sensação e da excitação, então, pela primeira vez na história da pesquisa científico-natural haveria a possibilidade de se estabelecer uma conexão

prática entre o mundo psíquico, subjetivo e o mundo físico, objetivo."

(W. Reich, 1950 - The developmental history of orgonomic functionalism. Part Two). 
Rastreamos, até o momento, alguns caminhos teóricos, clínicos e experimentais que levaram o autor a propor a existência de uma específica classe de sensações, por ele denominada de sensações vegetativas, sensações plasmáticas, sensações de órgão ou sensações orgonóticas. Reich se referiu com frequência, como pudemos notar, a esse tipo de apreensão sensorial, enfatizando que, caso o encouraçamento fosse terapeuticamente minimizado, o contato do indivíduo com suas próprias sensações plasmático-vegetativas poderia desempenhar importante papel em seu bem-estar.

Deixaremos momentaneamente de lado, agora, as incursões reichianas pelos terrenos da Biologia e Neurologia, e prosseguiremos nossa averiguação sobre a sensorialidade na obra do autor retomando alguns caminhos - teóricos e epistemológicos - percorridos por ele no campo da Psicologia. Para tal, examinaremos, em um primeiro momento, as críticas de Reich às tentativas wundtianas de abordar experimentalmente a esfera sensorial e os fatores que o levaram a crer que a psicanálise teria chegado muito mais perto da mente humana do que a psicologia laboratorial do final do século XIX e início do século $X X$. Veremos, em seguida, como o jovem Reich - questionando aspectos da psicologia experimental de sua época e inspirando-se em certas teses freudianas - esforçouse em articular, de uma nova perspectiva, os fenômenos da sensação e excitação, e como essa articulação norteou toda a sua subsequente produção científica e epistemológica.

No decorrer dessas análises perceberemos o quão Reich esteve interessado, desde o primeiríssimo estágio de sua obra, em encontrar perspectivas teóricas que 
ultrapassassem as limitações epistêmicas presentes, a seu ver, na psicologia experimental e pudessem alçar o estudo do psiquismo ao campo das ciências naturais. Notaremos, ainda, que seu projeto de parear sensação e excitação procurou dar resposta a um problema que o incomodava, também, desde o início de sua produção: a possível articulação entre os universos psico-qualitativo e energético-quantitativo. Aliás, dois debates essencialmente epistemológicos $-\mathrm{a}$ construção de uma psicologia científico-natural e a relação intensivo/extensivo permearam, como teremos oportunidade de observar, a análise reichiana da sensorialidade.

Iremos nos deparar novamente, ao longo deste capítulo, com autores que influenciaram significativamente as pesquisas de Reich sobre o fenômeno sensorial. Resgatando certas ideias formuladas por Lange, Bergson, Semon e Freud, procuraremos analisar, de forma breve, algumas contribuições desses estudiosos para a concepção geral de sensação adotada por Reich e para o seu intento de vincular a apreensão sensorial e a dimensão energética. Nesse contexto daremos destaque à forte presença do pensamento de Lange no trabalho reichiano.

Constataremos, por fim, que mesmo as incursões de Reich por searas psicológicas desaguaram na questão da motilidade plasmática.

\subsection{Psicologia como ciência natural}

O antigo tema da apreensão sensorial marcou presença, como pudemos observar no capítulo anterior, em campos tão distintos quanto a teoria protoplasmática e a fisiologia cerebral, constituindo-se, também, em um 
importante tópico da nascente "psicologia científica" (FREEDHEIM; WEINER; 2003, p. 1, tradução nossa) da segunda metade do século XIX.

Reich estava bastante interessado, especialmente na época em que atuou como psicanalista (1920-1934), na possível existência de uma "psicologia verdadeiramente científico-natural" (REICH, 1950b, p. 5, tradução nossa, grifo do autor) e tinha algum conhecimento sobre a maneira pela qual a incipiente ciência psicológica vinha abordando os fenômenos sensoriais. Logo à frente examinaremos as apreciações do autor acerca de alguns procedimentos da psicologia experimental de sua época, assim como a linha investigativa que ele próprio veio a adotar - o vínculo sensação-excitação -, linha essa que estaria, a seu ver, mais afinada com uma perspectiva psicológica de índole científico-natural. Por agora, iremos nos referir brevemente a um estudioso que esteve entre as mais importantes influências intelectuais da obra reichiana: o ativista político, jornalista e filósofo alemão Friedrich Albert Lange (1828-1875). Duas razões nos levam ao encontro do filósofo neste momento de nossa pesquisa: ele deu importante contribuição para a construção do programa teórico da ciência psicológica (TEO, 2002) e, muito provavelmente, influenciou significativamente a concepção reichiana de sensação, no que concerne à caracterização geral desse fenômeno e ao seu valor para a experiência humana. Comecemos, então, resgatando algumas ideias do pensador.

\subsubsection{Psicologia sem alma}

Lange produziu um amplo estudo na área da Teoria do Conhecimento, que marcou não apenas Reich, mas também outras influentes personalidades, tais como o filósofo Friedrich Nietzsche, o filósofo e psicólogo Franz Brentano (1838-1917), o 
médico e psicólogo Wilhelm Wundt (1832-1920) e o físico Albert Einstein (18791955). Trata-se da obra Geschichte des Materialismus und Kritik seiner Bedeutung in der Gegenwart ("História do materialismo e crítica de sua significação atual"), ${ }^{44}$ publicada em 1865 e considerada, por alguns estudiosos, como uma das mais significativas produções filosóficas do século XIX (TEO, 2002).

Percorrendo a história do materialismo desde os primeiros filósofos gregos até Kant, e deste até importantes pensadores e cientistas do século XIX, inclusive Marx e Darwin, o ambicioso estudo de Lange impressionou o jovem Reich e, como veremos mais adiante, continuou repercutindo ao longo de sua obra. Uma das provas desse contínuo interesse vem da terceira esposa do cientista, Ilse Ollendorff (1909-2008). Na biografia que escreveu a respeito do marido, Ollendorff relatou que ele frequentemente dizia que a Geschichte des Materialismus "deveria constar de toda biblioteca" e relembrou ainda que, nos quatorze anos em que estiveram casados, o fato de ela nunca ter podido estudar o livro resultou em "frequentes discussões” (OLLENDORFF DE REICH, 1978, p. 143). Em Ether, God and Devil, Reich, além de fazer elucidativas alusões a Geschichte des Materialismus (como veremos mais à frente), citou Lange como uma de suas principais referências teóricas (REICH, 1949/1973b).

Tecendo uma série de reflexões epistemológicas que ecoaram intensamente nos debates, entre o final do século XIX e início do século XX, a respeito da constituição e escopo da ciência psicológica, Lange esboçou, como ponderou um comentador, o programa teórico geral de uma "psicologia objetiva"

\footnotetext{
${ }^{44}$ Recorremos aqui a duas versões da obra do pensador alemão: The history of materialism and criticism of its present importance (LANGE, 1865/1950) e aos dois volumes de Histoire de matérialisme (LANGE, 1865/1877, 1865/1879).
} 
aproximadamente "meio século antes de Jonh Watson (1878-1958) expressar suas ideias” (TEO, 2002, p. 286, tradução nossa). E não é improvável, a nosso ver, que essas reflexões langeanas estivessem de alguma forma presentes para Reich quando, na década de 1920 , ele se perguntava se poderia haver "uma psicologia científico-natural no stricto sensu da palavra” (REICH, 1942/1989, p. 91, tradução nossa).

Em sua Geschichte des Materialismus, Lange criticou as abordagens psicológicas que adotavam como objetos de estudo, exclusivamente, certos conceitos filosóficos (por exemplo, alma e vontade) e recorriam à introspecção como método investigativo. Fomentando, em sua época, uma "verdadeira cruzada" (ARAUJO, 2007, p. 238) para livrar a reflexão psicológica de seus vícios metafísicos, o filósofo propôs a construção de uma Psychologie ohne Seele - uma “psicologia sem alma” (LANGE, 1865/1879, vol. 2, p. 403, tradução nossa). Para Lange, não haveria a menor razão "para se admitir uma alma” (p. 402, tradução nossa), qualquer que fosse o sentido, mais ou menos preciso, que se atribuísse ao termo. A psicologia científico-natural precisaria se pautar, a seu ver, não por conceitos filosóficos, mas pela investigação experimental dos eventos psíquicos, distanciando-se, dessa forma, do "turbilhão metafísico" suscitado por noções como “alma” e "substância" (p. 398, tradução nossa). Pois a moderna perspectiva científica, à qual a psicologia necessitaria se associar, não deveria se preocupar em encontrar a essência última ou substrato dos acontecimentos mentais, mas sim, em retratar o continumm dos fenômenos psíquicos em suas relações dinâmicas e dependências recíprocas, substituindo a visão substancialista por uma perspectiva relacional, 'funcional', processual. 
O campo de pesquisa dessa "nova" ciência psicológica seria, no entendimento langeano, bastante amplo. Caberia à psicologia se dedicar não somente "aos fatos da vida sensível”, mas também, "ao estudo do comportamento e da linguagem humanas", podendo, inclusive, ir além e dirigir sua atenção para "todas as manifestações da vida", desde que permitissem extrair conclusões sobre “a natureza e o caráter do homem” (LANGE, 1865/1879, vol. 2, p. 411, tradução nossa).

Lange era da opinião, ainda, que a maior parte dos ramos da psicologia teria grande sucesso caso adotasse o “método somático": uma orientação de pesquisa que deveria contemplar, o máximo possível, os processos corporais que estariam “indissolúvel e forçosamente ligados aos fenômenos psíquicos”. Caberia aos psicólogos determinar as bases físicas ou fisiológicas dos eventos mentais, sem, contudo, cometer reducionismos epistemológicos que perigosamente entronassem o mecano-materialismo como visão de mundo privilegiada, totalizadora e absoluta. Ainda que o "método somático" pudesse ajudar a construir e validar a psicologia científico-natural, os “processos corpóreos", na opinião do pensador, jamais deveriam ser encarados à maneira dos "materialistas", ou seja, como "fundamento último dos fenômenos psíquicos” (LANGE, 1865/1879, vol. 2, p. 418, tradução nossa). ${ }^{45}$

Entre os autores que ouviram o chamado de uma psicologia não essencialista e se propuseram a "reservar aos estudos psicológicos um território próprio" (FIGUEIREDO; DE SANTI, 2004, p. 13) estava o médico, filósofo e psicólogo alemão

\footnotetext{
${ }^{45} \mathrm{O}$ ponto de vista idealista também seria fundamental, de acordo com Lange, para o desenvolvimento da ciência, como veremos mais adiante. Quanto ao método somático proposto pelo filósofo alemão, é de se supor que essa sugestão langeana tenha alimentado, de forma mais ou menos direta, o interesse de Reich pelas bases biológicas, ou melhor, bioenergéticas dos fenômenos psíquicos.
} 
Wilhelm Wundt (1832-1920). Wundt realçou que, entre ele e Lange, havia diferenças metodológicas (Lange, como comentamos há pouco, não via com bons olhos o método da introspecção psicológica), mas admitiu explicitamente a influência positiva das proposições langeanas em seus estudos na área da psicologia (ARAUJO, 2007). Dado que examinaremos, logo a seguir, certas críticas de Reich à psicologia experimental de Wundt, interromperemos momentaneamente nossas apreciações sobre Lange e retomaremos alguns aspectos da teorização wundtiana.

Tentando romper, como sugerira Lange, os "laços tradicionais com a especulação metafísica" e se aproximar das ciências naturais, Wundt concebeu, como explica um comentador, um amplo programa no campo da ciência da mente, programa esse que abarcava “desde os processos psíquicos elementares até os mais altos níveis da vida" (ARAUJO, 2007, p. 27). Pesquisador extremamente erudito, o médico alemão circulava com desenvoltura, não apenas nos terrenos da psicologia e fisiologia, mas também em áreas como filosofia e linguística, tendo como pressuposto que a ciência psicológica jamais "poderia prescindir de uma fundamentação filosófica sólida de seus princípios e conceitos” (ARAUJO, 2009, p. 219).

Em sua clássica obra Grundzüge der physiologischen Psychologie, Wundt esforçou-se, desde a primeira edição de 1874, em demonstrar que existiria uma conexão direta entre a psicologia e a fisiologia e que os objetos de estudo dessas disciplinas seriam intimamente relacionados (WUNDT, 1874/1904). ${ }^{46}$ No entanto, ele considerava a fisiologia, como admitira em carta enviada em 1872 à sua futura esposa, tão somente "um estágio preparatório para, a partir da vida corpórea, com

\footnotetext{
${ }^{46}$ Valemo-nos aqui da tradução norte-americana da obra - Principles of Physiological Psychology -, publicada em 1904 e realizada por Edward Titchener (a partir da quinta edição alemã, de 1902).
} 
a qual esta ciência se ocupa, lançar várias pontes para chegar ao lado da vida mental” (WUNDT, 1872, citado em ARAUJO, 2007, p. 153).

Uma dupla de comentadores destacou que, para o médico e psicólogo alemão, as “funções mentais mais simples, como a sensação e a percepção" seriam passíveis de estudos laboratoriais, ao passo que os "processos mentais superiores, como a aprendizagem e a memória" fugiriam ao controle experimental e exigiriam abordagens semelhantes às empregadas (usando-se uma terminologia mais atual) “na antropologia, na sociologia e na psicologia social” (SCHULTZ; SCHULTZ, 2009, p. 83). Wundt estabeleceu, assim, uma distinção entre "a psicologia individual, fisiológica ou experimental" e a "psicologia dos povos (Völkerpsychologie)". Se a primeira poderia ser alcançada por meio da experimentação, a segunda exigiria, contudo, uma análise profunda dos "fenômenos culturais e coletivos (linguagem, mito, religião etc.)" (ARAUJO, 2009, p. 214). A associação das duas esferas possibilitaria, na perspectiva wundtiana, um entendimento mais amplo da vida mental.

No pioneiro e antológico Laboratório de Psicologia Experimental de Leipzig, fundado por Wundt em 1879, foram realizadas cerca de uma centena de investigações marcadamente experimentais. De acordo com um levantamento realizado pelo psicólogo e historiador da ciência Edwin Boring (1886-1968), metade das pesquisas laboratoriais empreendidas por Wundt e seus alunos inseria-se na área da sensação e da percepção: “Em termos de percepção, os wundtianos estudaram temas como as imagens residuais positivas e negativas, o contraste visual e a percepção de tamanho, profundidade e movimento" (GOODWIN, 2010, p. 126). Boring constatou, ainda, que aproximadamente $17 \%$ dos experimentos procuravam medir os tempos de reação, ou seja, o período de tempo que o sujeito 
do experimento precisava para responder a um dado estímulo (HOTHERSALL, 2006, p. 112).

Foram abordagens experimentais desse tipo, acerca do fenômeno sensorial, que Reich criticou com veemência em suas breves apreciações sobre a psicologia wundtiana. Seria preciso, a seu ver, investigar a sensorialidade a partir de outro ponto de vista, como veremos a seguir.

\subsubsection{Energia e psiquismo}

Havíamos mencionado que Reich se mostrou bastante interessado, em especial no primeiro estágio de sua produção, por uma possível psicologia científico-natural. Envolvendo-se, quando trabalhava como psicanalista em Viena (1919-1930) e Berlim (1930-1933), em debates relativos ao status científico da psicologia, ele defendeu o ponto de vista de que a Psicanálise continha muito mais 'cientificidade' do que a abordagem experimental de Wundt.

Tomando como ponto de partida esse posicionamento do autor, examinaremos as razões que o levaram a afirmar que a teoria freudiana seria mais consistente do que a psicologia experimental wundtiana. E veremos como esse debate acerca da cientificidade da psicologia contribuiu para que Reich propusesse uma nova diretriz investigativa: o vínculo dialético entre sensação de prazer e excitação sexual somática.

Comecemos pinçando um comentário feito por Reich quando ele contava com 53 anos de idade e já estava um bom tempo distante - científica e epistemologicamente - do meio psicanalítico. Discorrendo sobre a época em que ingressou na Associação Psicanalítica, o autor afirmou ter identificado, no começo 
de sua carreira, uma sólida fundamentação científica na obra freudiana; a seu ver, a psicanálise daquele período ainda não teria perdido "sua orientação energética, isto é, científico-natural” (REICH, 1950b, p. 4, tradução nossa).

Na entrevista que concedeu ao The Sigmund Freud Archives, em 1952, Reich mencionou que havia se sentido bastante atraído, no início da década de 1920 , pela teoria freudiana da libido, pois ela teria incorporado o "princípio científiconatural da quantidade de energia" (HIGGINS; RAPHAEL, 1972, p. 122, tradução nossa). Por meio da teoria da libido a psicologia, na avaliação do autor, vinculou-se "à ciência natural pela primeira vez na história da ciência" (p. 126, tradução nossa grifo do autor). Nesse depoimento de 1952, Reich comentou, ainda, que a perspectiva energética freudiana parecia-lhe cientificamente mais significativa do que a teoria do inconsciente:

\begin{abstract}
Freud basicamente descobriu o princípio de funcionamento da energia no aparelho psíquico. O princípio de funcionamento da energia. Foi o que o distinguiu dos demais psicólogos. Não tanto a descoberta do inconsciente. 0 inconsciente, a teoria do inconsciente, foi uma consequência, a meu ver, de um princípio que ele introduziu na Psicologia. Tratava-se [...] do princípio científico-natural da energia a 'teoria da libido' (HIGGINS; RAPHAEL, 1972, p. 15, tradução nossa, grifo do autor).
\end{abstract}

Segundo os relatos reichianos, o próprio Freud considerava como um de seus grandes feitos a proposição de que uma ideia não seria ativa por si mesma, mas sim, porque estaria associada a "certo investimento" ou "quantidade de energia" (HIGGINS; RAPHAEL, 1972, p. 120, tradução nossa).

Essa perspectiva energética freudiana teria se inspirado, de acordo com Reich, na "física clássica": da mesma forma que, na natureza inanimada, a 
"massa" sofre a ação de "forças", as "ideias" ou conteúdos psíquicos seriam movidos por "quantidades de energia". As "ideias" corresponderiam à noção de matéria e os “'impulsos”" (a Trieb freudiana), à noção física de força (REICH, 1950b, p. 5, tradução nossa). Essa influência da Física pode efetivamente ser observada em Die Abwehr-Neuropsychosen ("As neuropsicoses de defesa"), ${ }^{47}$ um trabalho redigido na fase inicial da obra freudiana:

[...] nas funções psíquicas deve-se distinguir algo (soma de afeto, magnitude de excitação) que possui todas as características de uma quantidade, embora não tenhamos meios de medi-la; algo passível de aumento, diminuição, deslocamento e descarga, que se espalha sobre os traços mnêmicos das representações como uma carga elétrica o faz pelas superfícies dos corpos (FREUD, 1894/1973a, p. 176-177, tradução nossa).

Foi, em suma, na obra freudiana que Reich identificou a "primeira tentativa de se delinear uma psicologia realmente científico-natural no início do século XX" (REICH, 1950b, p. 5, tradução nossa), não na produção wundtiana. Ele relembrou que, em sua época de psicanalista, ouvia frequentemente a crítica de que a teoria psicanalítica não pertencia ao campo da ciência natural, pois o freudismo não teria conseguido associar a análise qualitativa à objetivação quantitativa dos fenômenos. Nessas reminiscências o autor mencionou os argumentos que forjara, no período 1920-1934, para defender a cientificidade da psicanálise. Se a psicologia experimental de Wundt deveria ser considerada - por aferir quantitativamente as “reações humanas” - como a única abordagem psicológica “"científica””, e se a psicanálise - por se dedicar tão somente a estabelecer "relações (de significados) entre fenômenos psíquicos que se apartaram uns dos outros" - careceria de

\footnotetext{
${ }^{47}$ Recorremos aqui a uma tradução para o espanhol, do texto freudiano (FREUD, 1894/1973a).
} 
cientificidade, então, ponderou Reich, deveria haver algo de errado ou "falso" na ciência natural. Pois, na avaliação reichiana, Wundt e seus discípulos nada conheceriam da "realidade viva do ser humano". Tomando como exemplo certas pesquisas conduzidas no Laboratório de Leipizig, que mediam tempos de reação, Reich criticou a tentativa de entender aspectos do ser humano por meio de experimentos que computavam o "número de segundos" que o indivíduo precisava “para reagir à palavra-estímulo “cão””. A psicanálise, por sua vez, teria procurado formas mais eficazes de compreender o funcionamento humano, examinando "a maneira pela qual a pessoa lida com seus conflitos, e as motivações que produzem suas ações” (REICH, 1942/1989, p. 92, tradução nossa). ${ }^{48}$

Considerando Wundt como um "mecanicista" (REICH, 1996b, p. 63, tradução nossa) e as investigações do Laboratório de Leipizig - a exemplo das que aferiam a prontidão perceptiva - como excessivamente superficiais no que concerne ao entendimento da vida psíquica humana, Reich vislumbrou, no estudo do vínculo entre sensação e excitação, uma diretriz de pesquisa mais sólida e promissora para uma psicologia de orientação científico-natural. Tal direção de pesquisa esbarrava, porém, em uma complexa questão epistemológica: os problemas referentes à possível associação entre as esferas intensiva e extensiva.

\footnotetext{
48 Difícil saber se Reich estava inteirado da outra faceta da produção intelectual de Wundt, a Völkerpsychologie ou "psicologia dos povos", a qual complementaria, na perspectiva wundtiana, a pesquisa experimental, incrementando significativamente o estudo das leis gerais da vida psíquica. Como explica um comentador da obra do médico e psicólogo alemão, a Völkerpsychologie teria por objeto os "produtos mentais surgidos ao longo da história, como a linguagem, a religião, os mitos e os costumes": "Nos últimos 20 anos de sua vida (1900-1920), Wundt dedicou-se principalmente a esse empreendimento - baseando-se sempre em estudos e relatos linguísticos, históricos e etnológicos - que teve como resultado dez extensos volumes, além de ensaios isolados" (ARAUJO, 2009, p. 216).
} 


\subsubsection{Quantitativo e qualitativo}

Para Reich, o campo da psicologia sofria de uma profunda cisão entre a dimensão qualitativa e a dimensão quantitativa dos fenômenos. Julgando necessário encontrar saídas que, a seu ver, fossem menos mecanicistas do que as apresentadas pela psicologia experimental da época, ele saiu em busca de soluções científico-naturais para o problema do vínculo entre qualidade e quantidade ou, como veremos a seguir, do vínculo entre o âmbito psíquico e o âmbito energético.

A vida mental, no entendimento reichiano, pertenceria inequivocamente ao universo qualitativo. Em escritos da maturidade, o cientista, já distante teoricamente do freudismo, caracterizou o psiquismo como o “âmbito das sensações, percepções e ideias” (REICH, 1952/1991b, p. 3-4, tradução nossa), considerando a apreensão sensorial como seu aspecto nuclear: “É necessário limitar o conceito de 'psíquico’ à esfera das sensações e, assim, utilizá-lo para descrever apenas a experiência subjetiva dos processos vitais objetivos" (REICH, 1950/1990e, p. 11, tradução nossa). Afinal, o autor partia do pressuposto de que a sensação seria a única via de acesso "ao entorno e à nossa própria organização" (REICH, 1944/1991a, p. 28, tradução nossa $)^{49}$ e que a sensação estaria entre "as experiências mais diretas e menos duvidosas do organismo vivo" (REICH, 1949/1973c, p. 87, tradução nossa).

Essas proposições reichianas acerca do papel e valor da apreensão sensorial receberam, certamente, influências de Semon e Bergson, como veremos mais

\footnotetext{
${ }^{49}$ Examinaremos em outro momento o significado do termo "organização" para Reich.
} 
adiante. Mas é de se supor que tenham encontrado inspiração, também, em certas ideias de Lange.

Desenvolvendo, em seu Geschichte des Materialismus, uma ampla discussão sobre a dimensão sensorial, o filósofo alemão enfatizou que o mundo das sensações seria “o único mundo dado" (LANGE, 1865/1950, vol. 2, 2.a seção, p. 328, tradução nossa) e que a sensação seria "real e dada" (p. 326, tradução nossa). Opondo-se às teorias de sua época que concebiam os movimentos dos átomos no cérebro como algo objetivo e as sensações, como simples miragens ou subprodutos dessas movimentações, o filósofo procurou demonstrar que a apreensão sensorial representava um ingrediente fundamental da vida intelectual humana:

Quando pressupomos que a consciência pode existir sem a sensação, somos reféns de uma sutil confusão. Pode acontecer de a consciência se mostrar bastante vívida, voltando-se para as questões mais elevadas e significativas, e, assim, as sensações parecerem quase imperceptíveis. Mas as sensações estão sempre em ação, sensações cujas relações, harmonia ou desacordo determinam o tipo e valor das ideias percebidas pela consciência, da mesma forma que uma catedral é construída por pedras brutas, ou que um desenho complicado é composto por linhas materiais finas e delicadas, ou que uma flor é formada por matéria organizada (LANGE, 1866/1877, p. 30, tradução nossa). ${ }^{50}$

Essa perspectiva, de que as sensações funcionariam como tijolinhos básicos da vida psíquica, também pode ser identificada no trabalho do médico e biólogo alemão Richard W. Semon (1859-1918), outra influência central na obra reichiana (REICH, 1949/1973c, 1996b; BEDANI, 2007b).

\footnotetext{
${ }^{50}$ Reich pareceu ecoar ou ao menos estar afinado com o pensamento langeano quando afirmou, em 1949, que "o tipo de autopercepção determina o tipo de consciência" (REICH, 1949/1973h, p. 442, tradução nossa, grifos do autor). Avaliaremos mais adiante as noção de autopercepção e consciência na produção reichiana.
} 
No entendimento de Semon, as sensações precisariam ser vistas como “dados imediatos" e "fundamentais". Como uma espécie de informação básica e pura, a sensação, na visão do biólogo, apontaria para o que é conhecido de imediato, não para algo que precisaria ser definido "em relação a algo mais simples ou mais bem conhecido" (SEMON, 1909/1923, p. 58, tradução nossa). ${ }^{51}$

Abordando o fenômeno da memória em obra publicada em 1909, Die Mnemischen Empfindungen (“As sensações mnemônicas”), ${ }^{52}$ Semon deu ao primeiro capítulo do livro o título “Definição do assunto. Sensação e excitação”. Procurando estabelecer vínculos entre o registro “energético” e o registro sensorial, o biólogo ponderou que cada "processo específico de excitação" teria como correspondência uma “sensação concreta” (SEMON, 1909/1923, p. 60, tradução nossa). Uma dada “sensação de luz", por exemplo, equivaleria a uma “excitação” ou a "processos

\footnotetext{
${ }^{51}$ Interessante observar como esse entendimento acerca da sensação aproxima-se da concepção de Primeiridade formulada pelo filósofo, cientista e matemático norte-americano Charles Sanders Peirce (1839-1914). Peirce, no decorrer de suas diversificadas investigações, acreditou ter identificado um trio de categorias universais: Primeiridade (Firstness), Secundidade (Secondness) e Terceiridade (Thirdness). A categoria da Primeiridade foi definida pelo pensador como "o modo de ser daquilo que é tal como é, positivamente e sem referência a qualquer outra coisa". 0 indivíduo, na experiência da Primeiridade, teria acesso a uma mera qualidade, não chegando sequer a perceber, nessa vivência tão simples e imediata, o passar do tempo. As "típicas ideias de Primeiridade" representariam, de acordo com o filósofo, "qualidades de sentimentos ou mera aparência" (PEIRCE, citado em QUEIROZ, 2004, p. 27). Tais qualidades de sentimentos diriam respeito ao que está "direta e imediatamente na consciência, a qualquer instante, tal como é, sem considerar o que significa, que partes o compõem, o que causa ou qualquer de suas relações com qualquer outra coisa". Assim, "uma qualidade de sentimento - por exemplo, uma certa cor vermelha - pode ser imaginada como constituindo o todo da experiência de alguém, sem qualquer sentido de começo, fim ou continuação, sem qualquer autoconsciência distinta do sentimento da cor, sem comparação com outros sentimentos - e ainda continuar a ser a própria cor que vemos" (PEIRCE, citado em PIGNATARI, 2004, p. 42-43). Além de estar associada a esse tipo de puro "sentimento", a categoria da Primeiridade apontaria para os conceitos de originalidade, presentidade, espontaneidade, imediaticidade, qualidade, impressão. A Secundidade, por sua vez, teria início quando um acontecimento da ordem da primeiridade estabelece relação com um segundo fenômeno, dando origem assim a uma polarização ou oposição entre dois objetos, a uma binariedade que se expressaria por dualismos como reação/luta e esforço/resistência. A Terceiridade (Thirdness), por fim, apresentaria um caráter aglutinador, remetendo às ideias de representação, lei, hábito, memória, e estaria, dessa forma, relacionada à "consciência sintética, reunindo tempo, sentido de aprendizado, pensamento" (PEIRCE, 2000, p. 14).
}

${ }^{52}$ Valemo-nos aqui de uma tradução da obra para a língua inglesa: Mnemic psychology (SEMON, 1909/1923). 
energéticos” (físicos) que ocorreriam "na retina, nervo ótico e área visual do cérebro" (p. 62, tradução nossa) (como veremos mais à frente, Reich, no início de sua produção, deslocou essa perspectiva investigativa semoniana para o campo da reflexão psicanalítica, procurando avaliar as possíveis conexões entre a sensação de prazer e a excitação sexual somática).

Além das influências que Lange e Semon possam ter exercido no entendimento de Reich acerca da imediaticidade da apreensão sensorial, cabe indicar, ainda, que certas análises bergsonianas a respeito da sensação também ecoaram na reflexão reichiana. Aspectos do pensamento do filósofo francês marcaram, aliás, a produção de Reich (ALBERTINI, 1994), que, em sua época de estudante de medicina, chegou a ser alcunhado de "bergsoniano maluco" (REICH, 1942/1989, p. 23, tradução nossa). Três obras do célebre pensador receberam então grande atenção do jovem universitário: Essai sur les données immédiates de la conscience ("Ensaio sobre os dados imediatos da consciência"), Evolution créatrice ("Evolução criadora") e Matière et mémoire ("Matéria e memória”) (REICH, 1942/1989).

Para Bergson, as sensações apenas poderiam ser apreendidas no plano qualitativo e não estariam, portanto, sujeitas à quantificação. Sublinhando, em seu Essai sur les donnés immédiates de la conscience, que o espaço maior contém o espaço menor ou que o número um está contido no número três, o filósofo, duvidando que essa lógica quantitativa pudesse se estender ao universo sensorial, indagou: "como uma sensação mais intensa conteria uma sensação de menor intensidade?” (BERGSON, 1889/1984a, p. 5, tradução nossa). As sensações psíquicas, na visão bergsoniana, caracterizar-se-iam exclusivamente por sua 
intensidade ou qualidade, não thes cabendo atributos como extensão ou quantidade, os quais deveriam ser conferidos tão somente aos processos físicos.

Reich, alinhado com Bergson, considerou, como observamos logo acima, que o fenômeno da sensação apontava inevitavelmente para o terreno qualitativo; o fenômeno da excitação, porém, remeteria, no entendimento reichiano, aos processos energéticos objetivos (físicos), naturais (existentes antes mesmo do surgimento da matéria viva) e passíveis de quantificação. Considerando que, no ser humano, a dimensão qualitativa teria como núcleo a sensação imediata e que a dimensão quantitativa teria como protótipo a excitação, Reich acalentou a possibilidade, desde o início de sua pesquisa, de identificar um terreno comum a essas duas instâncias. Resgatando, em trabalho publicado em 1950, suas embrionárias cogitações, ele fez um elucidativo comentário que, embora já o tenhamos citado, vale a pena transcrever novamente:

\footnotetext{
Eu sabia que se tivesse sucesso em encontrar o princípio comum de funcionamento da sensação e da excitação, então, pela primeira vez na história da pesquisa científico-natural haveria a possibilidade de se estabelecer uma conexão prática entre o mundo psíquico, subjetivo e o mundo físico, objetivo (REICH, 1950/1990e, p. 3, tradução nossa, grifo do autor).
}

Esse intento, de averiguar as relações entre sensação e excitação e buscar seu princípio de base, atuou como uma espécie de fio condutor da obra de Reich, desdobrando-se em estudos clínicos, laboratoriais e epistemológicos. Vejamos, a seguir, um pouco da história da pesquisa reichiana sobre o vínculo sensaçãoexcitação. 


\subsubsection{0 terceiro fator}

As primeiras formulações reichianas a respeito do pareamento sensaçãoexcitação foram publicadas no ano de 1923 em um artigo intitulado "Zur Triebenergetik" (Sobre a energética dos impulsos)..$^{53}$ Reich considerava esse escrito o marco inicial (científico e epistemológico) de sua obra (ORGONE INSTITUTE PRESS, 1953) e o reexaminou, ao menos em duas oportunidades, em seu período orgonômico. Em The function of the orgasm, de 1942, ele revelou que, com o ensaio sobre a energética dos impulsos sexuais, teria dado o primeiro passo, "de forma totalmente inconsciente", em direção à sua "posterior unificação do conceito quantitativo de excitação e do conceito qualitativo de prazer" (REICH, 1942/1989, p. 53, tradução nossa) (unificação essa que teria sido experimentalmente validada, posteriormente, por meio dos experimentos bioelétricos; voltaremos a essa questão, mais à frente).

Em "Zur Trieb-energetik" o autor se inspirou em certa diretriz investigativa semoniana, que mencionamos há pouco: a de que a sensação seria uma faceta psicológica da excitação ou, nas palavras do biólogo, “uma das muitas formas pelas quais as excitações materiais tornam-se conhecidas para nós” (SEMON, 1904/1921, p. 281, tradução nossa). Em seu artigo de 1923, o jovem médico-psicanalista reconheceu explicitamente que partia do ponto de vista semoniano de que toda sensação seria "acompanhada de um processo paralelo de excitação fisiológica no órgão correspondente", de forma que a apreensão sensorial deveria ser vista como “o aspecto psíquico do estímulo fisiológico" (REICH, 1923/1976c, p. 157, tradução

\footnotetext{
${ }^{53}$ Tivemos oportunidade de examinar detalhadamente, em outro trabalho (BEDANI, 2007a), o artigo "Zur Trieb-energetik".
} 
nossa). ${ }^{54}$ Ainda que pertencendo a domínios distintos, sensação e excitação seriam fenômenos indissociáveis, mutuamente dependentes (Reich averiguou essa retroalimentação, em seu estudo de 1923, tomando como ponto de partida fenomenológico as sensações sexuais prazerosas).

O autor estabeleceu, assim, um contexto para o estudo da sensorialidade: recusando-se a empreender uma análise atomista, ele não se voltou para os elementos constituintes da sensação, mas procurou, muito mais, abordá-la relacionalmente, examinando-a em seu vínculo com o fenômeno da excitação sexual. Seu projeto era, no entanto, mais ambicioso: ele esperava encontrar, como vimos logo acima, o fator de base que daria origem à sensação de prazer e à excitação sexual somática.

Em um texto de teor metodológico redigido no período norte-americano de seu trabalho, Reich revelou que, no decorrer da produção de "Zur Triebenergetik", suspeitou pela primeira vez que a sensação prazerosa e a excitação (ou impulso) sexual, além de estabelecerem entrelaçamentos dinâmicos, apresentariam um "princípio comum de funcionamento" que unificaria os dois fenômenos e seria mais profundo do que eles. Em um primeiro momento, Reich denominou, de forma vaga, esse princípio comum (ou função de base) de “atividade motora", cogitando que "impulso e prazer" seriam uma e mesma coisa em relação àquela atividade. Colocando a questão de outra maneira, o autor afirmou ter cogitado que a excitação corporal (ou o impulso) seria idêntica à sensação psíquica em relação a “um dado processo biológico, a atividade sexual

\footnotetext{
${ }^{54}$ Apesar de Reich ter identificado, nos estudos do biólogo alemão, um paralelismo entre sensação e excitação, Semon parecia estar mais próximo da perspectiva monista do que do paralelismo psicofísico. Semon acreditava que, "em uma excitação e em sua manifestação na sensação vemos não dois fenômenos, mas um único fenômeno, contemplado de dois pontos de vista diferentes". Por isso, não considerava adequado "nomear de 'paralelismo psicofísico' essa relação entre sensação e excitação" (SEMON, 1909/1923, p. 61, tradução nossa).
} 
motora" (REICH, 1950/1990d, p. 6, tradução nossa). Tal atividade motora representaria, em suma, um terceiro e mais profundo fator, do qual emergiriam a excitação somática e a agradável sensação sexual.

Em seu período orgonômico, Reich admitiu que não sabia muito bem, na época em que redigiu "Zur Trieb-energetik", o que seria aquela atividade motora. Com o avanço de sua pesquisa, ele chegou à conclusão, associando observações clínicas e laboratoriais, que a atividade motora diria respeito a uma "função" ou "movimento" do "aparato nervoso vivo" ou "sistema plasmático autônomo" (REICH, 1950/1990d, p. 11, tradução nossa, grifos do autor). A pulsatilidade biológica do protoplasma energeticamente excitado traduzir-se-ia, assim, psicologicamente em sensação de prazer e, somaticamente, em impulso sexual. ${ }^{55}$

Mas tais formulações são bem posteriores ao artigo de 1923. Se voltarmos a "Zur Trieb-energetik", notaremos que Reich, com esse ensaio, não apenas delineou uma linha investigativa (a conexão entre sensação e excitação), como também vislumbrou uma questão metodológica que se tornou central em sua obra:

Sensação e excitação são idênticas em relação a um princípio comum de funcionamento ainda indeterminado [a 'atividade motora']. Sensação é uma função da excitação, e excitação, por sua vez, é uma função da sensação. São inseparáveis e formam uma unidade funcional; ao mesmo tempo, não são idênticas, mas diferentes uma da outra [...]. Desse modo surgiu a primeira formulação da 'simultaneidade de identidade e antítese' (REICH, 1950/1990d, p. 6, tradução nossa).

\footnotetext{
${ }^{55}$ Cabe observar que Reich diferenciava os conceitos de somático e biológico. Para o autor, o domínio somático era mais superficial e abarcaria "os processos físico-químicos" dos tecidos, redutíveis às leis mecano-materialistas; por sua vez, o domínio biológico (ou bioenergético ou bio-orgonótico, termos equivalentes na segunda metade da produção reichiana) diria respeito a um nível de funcionamento mais profundo, justamente o da pulsação plasmática orgonótica. Em outras palavras, o "psíquico" e o "somático" seriam mais superficiais do que o "biológico" (REICH, 1952/1991b, p. 2, tradução nossa) e derivariam deste último.
} 
Dar-se-ia, em outras palavras, uma ordenação hierárquica em que a atividade motora ocuparia um estrato mais profundo, ao passo que o impulso (ou excitação) e a sensação de prazer seriam mais superficiais. Os três fenômenos ocorreriam, no entanto, simultaneamente, pois o surgimento dos dois fenômenos superficiais não acarretaria o desaparecimento da matriz. Haveria, na visão reichiana, “'simultaneidade de identidade e antítese”" (REICH, 1950/1990d, p. 6, tradução nossa) - uma lógica de ordenação intuída durante a redação de “Zur Trieb-energetik" e que, extrapolando os fenômenos abordados no artigo, tornou-se um princípio geral da abordagem epistemológica reichiana. ${ }^{56}$

Nessa busca por princípios unificadores, Reich caminhou em direção a estratos biológicos que seriam, a seu ver, mais profundos. Esses estratos biológicos ou bioenergéticos, por sua vez, o teriam conduzido a um terreno ainda mais amplo, representado por uma força ou potência que participaria intimamente dos processos vivos, mas que existiria antes deles e lhes daria sustentação: a energia orgone cósmica, como vimos brevemente no capítulo anterior.

\subsubsection{Para além da psicologia}

A título de síntese retomaremos, agora, aspectos do percurso de Reich, desde sua participação no movimento psicanalítico até seu distanciamento da teoria freudiana. Uma trajetória que, como vimos até o momento, deparou-se com

\footnotetext{
${ }^{56}$ É de se suspeitar que o conceito reichiano de princípio comum de funcionamento sofreu alguma influência das ideias de Lange, embora Reich não tenha, até onde temos conhecimento, admitido explicitamente tal influência. 0 que nos levou a essa hipótese foi uma ponderação do filósofo alemão em sua monumental obra, em que ele propôs, para lidar com as complexas relações entre o mundo material (físico) e o mundo sensorial (psicológico), que se buscasse por "uma terceira e desconhecida coisa como causa de ambos [os mundos]", pois isso poderia conduzir a investigação a um âmbito "mais profundo do que a simples identificação daqueles dois mundos" (LANGE, 1866/1950, vol. 2, 2.a seção, p. 328, tradução nossa, grifo do autor).
} 
complexos problemas relativos à construção de uma psicologia científico-natural, à possível associação entre o âmbito psíquico e o âmbito energético, à tentativa de identificar fatores que unificassem fenômenos dinamicamente entrelaçados e à busca por perspectivas epistemológicas não mecanicistas.

Comentamos anteriormente que Reich participou ativamente do movimento psicanalítico por aproximadamente quatorze anos, até que significativas diferenças "teóricas, metodológicas e políticas" havidas entre ele e a cúpula da Associação Psicanalítica Internacional (IPA) acabaram resultando em sua expulsão da instituição em 1934. O autor considerava a teoria da libido como eixo principal da obra freudiana, mas the pareceu que a maior parte dos psicanalistas estaria relegando o conceito de energia sexual a um segundo plano e produzindo, assim, uma "descientifização" da Psicanálise. Em determinado momento de seu período psicanalítico, Reich também passou a questionar veementemente, a partir de estudos teóricos e de sua experiência clínica, o conceito freudiano de impulso de morte (Todestrieb), além de se pôr a desenvolver uma metodologia terapêutica (a Análise do Caráter) que tinha como referencial de cura um conceito jamais aceito pelo meio psicanalítico, a potência orgástica. Houve, ainda, outro fator decisivo na exclusão de Reich dos quadros do movimento psicanalítico: o trabalho de orientação político-sexual que 0 autor desenvolveu, como apontamos anteriormente, no âmbito dos partidos de esquerda em Viena (1927-1930) e Berlim (1930-1933). Esse envolvimento político reichiano teria incomodado profundamente 
a cúpula da IPA, justamente no "delicado momento da ascensão de Hitler ao poder" (BEDANI; ALBERTINI, 2009). ${ }^{57}$

Ao se refugiar na Noruega em 1934, Reich retomou seu antigo intento de vincular os âmbitos psico-qualitativo e energético-quantitativo, contando agora com recursos laboratoriais. Por meio de seus experimentos bioelétricos, o cientista chegou à conclusão, como salientamos em outros momentos, que "a quantidade do potencial de superfície [da pele] e a intensidade das sensações erógenas ou vegetativas" seriam dimensões fenomênicas "funcionalmente idênticas" (REICH, 1937/1982b, p. 128, tradução nossa, grifo do autor). A qualidade/intensidade de uma dada apreensão sensorial mostrar-se-ia, de acordo com as pesquisas experimentais reichianas, indissociável da quantidade de carga presente em uma dada região da pele ou mucosas. Além disso, os dois registros se igualariam ou, como indicou o autor na citação acima, seriam funcionalmente idênticos no que concerne a um terceiro e mais amplo fator. Ainda que de naturezas bastante distintas, sensação e carga bioelétrica seriam indiferenciáveis ou se unificariam em seu denominador comum. Sempre em busca de princípios comuns de funcionamento, Reich, após algumas incertezas iniciais, localizou aquele fator de base na pulsatilidade plasmático-vegetativa.

O plasma vegetativo em estado de expansão, movendo-se em direção ao mundo, repassaria essa sua expansividade para o registro percepto-sensorial (incremento da sensação de prazer) e para o registro somato-energético (elevação do potencial bioelétrico). Em estado de contração, o plasma se retrairia, havendo,

\footnotetext{
${ }^{57}$ Vai além de nossos propósitos, aqui, examinar detalhadamente a participação de Reich no movimento psicanalítico, assim como o contexto histórico que conduziu a sua expulsão da agremiação. Uma análise pormenorizada do tema pode ser encontrada em Wagner (1995).
} 
simultaneamente, sensação de desprazer e diminuição da carga elétrica periférica (REICH, 1937/1982b).

Mesmo excluído da Associação Psicanalítica, Reich continuou buscando, na segunda metade da década de 1930, comprovações científico-naturais para certos conceitos freudianos. Acreditando, naquele momento, que a bioeletricidade representava a objetivação laboratorial da energia sexual sugerida por Freud, o autor fez o seguinte comentário em sua autobiografia científica: "O conceito freudiano de libido como medida da energia psíquica não é mais uma mera metáfora. Ele diz respeito aos processos bioelétricos concretos" (REICH, 1942/1989, p. 377, tradução nossa). ${ }^{58}$

Em seu período orgonômico (1939-1957), vivendo então nos EUA, Reich passou, contudo, a tomar distância cada vez maior em relação ao corpo teórico freudiano. Ainda que jamais tivesse deixado de assinalar a importância das ideias psicanalíticas para o primeiro estágio de sua produção, ele comentou por diversas vezes (HIGGINS; RAPHAEL, 1972; PLACZEK, 1981) que a Orgonomia destoava profundamente da psicanálise, no que tange ao seu objeto de estudo (as forças orgonóticas que, na visão reichiana, manifestar-se-iam nos domínios do orgânico e do inorgânico) e à sua base epistemológica (que teria como núcleo o princípio da simultaneidade de identidade e antítese).

Em carta com data de 14 de maio de 1947 e endereçada ao educador inglês Alexander S. Neill (1883-1973) (Neill e Reich mantiveram intenso vínculo de amizade por duas décadas), o cientista, referindo-se à ciência orgonômica, foi

\footnotetext{
${ }^{58}$ Reich certamente estava se referindo à definição que Freud deu da libido em "Três ensaios para uma teoria sexual", de 1905: "Estabelecemos o conceito de libido como uma força quantitativamente variável, que nos permite medir os processos e as transformações da excitação sexual" (FREUD, 1905/1973b, p. 1221, tradução nossa).
} 
bastante enfático: “Há quinze anos meu trabalho não tem, absolutamente, nada a ver com a psicanálise e suas diferentes variações. Há quinze anos um novo ramo da ciência natural, não da psicologia, está em plena atividade” (PLACZEK, 1981, p. 190-191, tradução nossa, grifo do autor).

No estágio orgonômico de sua produção, Reich estava, em suma, lutando “desesperadamente”, como ele próprio admitiu, "para não ser olhado como um ramo da psicanálise” (PLACZEK, 1981, p. 190-191, tradução nossa). Como observamos há pouco, ele também não nutria qualquer simpatia pela abordagem laboratorial wundtiana, além de ser um veemente crítico da "visão mecanicista da função cerebral” (REICH, 1949/1973h, p. 455, tradução nossa) e da “obsoleta localização cerebral das sensações e ideias” (REICH, 1949/1973g, p. 356, tradução nossa).

Descontente, em suma, com importantes orientações teóricas de sua época, o autor, como notaremos no próximo capítulo, irá se inspirar, para desenvolver suas pesquisas orgonômicas sobre a sensorialidade plasmática, na psicologia celular, uma linha de pesquisa praticamente esquecida, atualmente, pela História da Ciência.

\subsection{Considerações gerais}

No decorrer deste capítulo, tivemos oportunidade de retomar alguns estudiosos que influenciaram o entendimento de Reich acerca da apreensão sensorial, identificar a concepção filosófica geral de sensação com a qual ele operou, examinar seu interesse (na fase inicial de sua carreira) pela construção de

uma ciência psicológica (e as correlatas críticas que teceu à psicologia 
experimental de sua época), apontar seu anseio de articular a instância psíquica e a instância energética e resgatar seus estudos sobre o vínculo sensação-excitação (com seus desdobramentos teórico-epistemológicos).

Vimos que Reich partilhou do entendimento de que a sensação representaria um dado imediato ou direto, uma informação pura que, no ato de sua apreensão, praticamente independeria da relação com outros elementos psíquicos. Para formar esse ponto de vista acerca da imediaticidade do fenômeno sensorial, o autor certamente se inspirou, como tivemos oportunidade de observar neste capítulo, em algumas ideias de Semon e Bergson, e identificamos fortes indícios de que Lange tenha dado, também, importante contribuição. Apontamos a possibilidade, igualmente, de que a ênfase langeana em uma abordagem psicológica não metafísica e experimental tenha estimulado o interesse de Reich, no primeiro estágio de sua produção, por uma psicologia científico-natural.

Pautando-nos por uma pequena crítica de Reich aos experimentos wundtianos que, ao averiguarem a dinâmica percepto-sensorial, aferiam os tempos de reação do sujeito, observamos que o autor considerava tais experimentos como simplistas e pouco proveitosos para a compreensão do complexo funcionamento mental humano. No período em que atuou como psicanalista ele teria chegado à conclusão de que a teoria freudiana, quando comparada à psicologia experimental da época, disporia de recursos teóricos mais sofisticados para decifrar as motivações profundas dos conflitos psíquicos e estaria mais próxima da ciência natural, por operar com uma ampla gama de conceitos energéticos (libido, investimento, impulso, entre outros).

Fiel a sua perspectiva energética, o autor acreditou ter encontrado, no vínculo entre sensação e excitação, uma rota investigativa efetivamente científico- 
natural. Inspirando-se possivelmente na concepção langeana de que a sensorialidade desempenharia papel crucial na vida humana; apoiando-se nos referenciais energéticos freudianos; alinhando-se à perspectiva semoniana de que a apreensão sensorial estaria diretamente coligada à excitação, o jovem Reich procurou estabelecer conexões entre a sensação prazerosa e a excitação libidinal somática. Essa tentativa de vincular a esfera sensorial e o campo da excitação desdobrou-se, por sua vez, em estudos terapêuticos, laboratoriais e epistemológicos.

Baseando-se, inicialmente, apenas em sua experiência clínica, Reich propôs que a impotência orgástica estaria assentada em um distanciamento patológico entre sensação e excitação. Em um segundo momento, ele julgou ter confirmado experimentalmente, durante seus experimentos bioelétricos, a existência daquela cisão (e ter confirmado, também, a tese de que a potência orgástica unificaria a apreensão sensorial e a carga bioenergética). Suspeitando, desde o início de sua produção, que haveria um denominador comum da sensação e da excitação, o autor, pautando-se por suas pesquisas clínicas e laboratoriais, identificou aquela função-mãe na pulsatilidade plasmático-vegetativa. Pareceu-lhe, porém, que o conceito de fator de base não se restringia ao sistema sensação-excitação e que, em todos os processos energéticos funcionais (não mecânicos), haveria a possibilidade de existirem matrizes mais amplas ou profundas. Cruzando os resultados de diversas pesquisas suas, ele acreditou ter chegado a um princípio lógico geral: a simultaneidade de identidade e antítese. Estratos profundos do vivo e do cosmo seriam regulados, de acordo com o autor, por uma configuração hierárquica em que fenômenos de base dariam origem, sem se extinguir, a duas 
funções ao menos, com a peculiaridade de que a matriz e suas variações passariam a operar coligadas e simultaneamente.

Do ponto de vista reichiano, a apreensão sensorial seria, em suma, variação de um fenômeno mais profundo: a pulsatilidade plasmático-vegetativa. Em seu período orgonômico, o cientista aprofundou seus estudos sobre a articulação entre motilidade plasmática e sensação, procurando descrever em detalhes tal mecanismo. Esse desenvolvimento ocorreu, como veremos no próximo capítulo, no quadro de uma inédita teoria sobre as emoções. 


\section{SENSAÇÃO E EMOÇÃO}

"O ser humano provavelmente inventou a palavra 'emoção' [do latim ēmovēre: deslocar, mover para fora] baseando-se em suas sensações de órgão. [...] ele simplesmente descreveu seu estado interno de 'motilidade."'

(W. Reich, 1952 - The developmental history of orgonomic functionalism. Part Three). 
Os estudos de Reich acerca da sensorialidade se inspiraram, como temos observado, em diferentes fontes, foram continuamente permeados pelas buscas epistemológicas do autor e colocaram em destaque um específico gênero de apreensão perceptiva: as sensações plasmáticas, orgonóticas, vegetativas ou de órgão. Tais sensações, por sua vez, tomariam raízes, segundo o autor, em um fenômeno bastante primitivo: a motilidade (ou pulsação) do plasma vegetativo.

Pudemos notar, nos capítulos precedentes, que Reich indicou a pulsatilidade como uma das principais características do plasma celular e propôs que, em seres humanos, tal pulsatilidade seria coordenada por um sistema ou função vegetativa. 0 autor insistiu, ainda, que a motilidade plasmático-vegetativa humana teria raízes filogenéticas arcaicas, que remontariam ao funcionamento das criaturas unicelulares. De forma semelhante à contratilidade plasmática observável em determinados organismos unicelulares (e em alguns vermes e moluscos), o conteúdo plasmático-celular do ser humano também manifestaria dilatações e retrações.

Para Reich, os movimentos plasmáticos de alongamento e recolhimento poderiam, como vimos anteriormente, encontrar alguma expressão perceptiva. No entanto, do ponto de vista reichiano essa reverberação sensorial não seria exclusividade do indivíduo humano: "O ser humano e a ameba são funcionalmente idênticos no que tange às funções protoplasmáticas de expansão prazerosa e contração angustiante" (REICH, 1949/1973c, p. 111, tradução nossa). Movimento plasmático e certa apreensão sensorial seriam, assim, faculdades que se estenderiam dos unicelulares aos multicelulares. 
Fizemos menções, nos capítulos precedentes, à proposição reichiana de que os seres vivos, em geral, seriam dotados de alguma sensorialidade. Averiguaremos de forma mais detalhada, agora, as raízes históricas de tal concepção, para, em seguida, examinarmos como Reich interpretou o papel dessa rudimentar sensorialidade no funcionamento psíquico humano.

Iniciaremos nossas análises demonstrando que o autor, além de herdeiro da teoria protoplasmática, foi fortemente influenciado por uma orientação investigativa conhecida como psicologia celular, formada por um grupo de cientistas e filósofos que, entre o final do século XIX e início do século XX, apostou na tese de que os micro-organismos (e cada unidade celular dos pluricelulares) carregariam as matrizes da sensorialidade e do psiquismo humanos.

Após retomarmos esses antecedentes históricos, averiguaremos as tentativas de Reich, especialmente no estágio orgonômico de sua produção, de articular funções perceptivas básicas (que teriam profundas raízes filogenéticas) e certos estados psicológicos humanos. Veremos então que esse intento deu-se no quadro de uma original teoria orgonômica sobre as 'emoções' e a 'expressão emocional' - a emoção como a própria motilidade plasmática e a expressão emocional como manifestação externa dessa motilidade. Nessa perspectiva, determinadas vivências psíquicas seriam indissociáveis da condição 'emocional’ (plasmática) do indivíduo.

Por fim, analisaremos o crucial papel que, na visão reichiana, os primitivos níveis sensoriais desempenhariam na formação, desenvolvimento e coesão da consciência humana.

Comecemos nossas averiguações resgatando a linha investigativa que trabalhou com a possibilidade de que o protoplasma conteria, em si mesmo, rudimentos de uma vida psíquica. 


\subsection{Psicologia celular}

Pudemos observar, desde o início do presente trabalho, que Reich não é o autor da asserção (embora tenha se filiado a ela) de que haveria, no protoplasma de unicelulares e pluricelulares, algum gênero de apreensão sensorial. Diversos estudiosos, como vimos anteriormente, fizeram menções gerais, no quadro da multifacetada teoria protoplasmática, a uma irritabilidade celular ou a uma primitiva capacidade de resposta aos estímulos.

Alguns cientistas, porém, se dedicaram a investigar especificamente, entre o final do século XIX e o início do século XX, a tese de que as criaturas unicelulares seriam portadoras de matrizes sensoriais (e até mesmo psíquicas) que teriam, de alguma forma, chegado aos organismos multicelulares, inclusive, o ser humano. Como demonstraram Judy J. Schloegel e Henning Schmidgen no elucidativo ensaio “General Physiology, Experimental Psychology, and Evolutionism: Unicellular Organisms as Objects of Psychophysiological Research, 1877-1918” (Fisiologia geral, psicologia experimental e evolucionismo: Organismos unicelulares como objetos da pesquisa psicofisiológica, 1877-1918), uma corrente de pesquisa, conhecida como psicologia celular, tentou estabelecer, a partir do estudo experimental de certos micro-organismos, as bases não apenas da sensorialidade, mas também do funcionamento psicológico humano.

Apoiando-se em farto material histórico, Schloegel e Schmidgen esclareceram que, na virada do século XIX para o século XX, influentes estudiosos tais como o biólogo Ernest Haeckel, o fisiologista alemão Max Verworn, o psicólogo francês Alfred Binet e o filósofo Henri Bergson - adotaram o ponto de vista de que 
o protoplasma, em seres unicelulares e em cada célula dos organismos pluricelulares, conteria não apenas as matrizes da vida fisiológica em geral, mas também, da vida psicológica (SCHLOEGEL; SCHMIDGEN, 2002).

Concebendo os unicelulares como entidades vivas elementares, os adeptos da noção de psicologia celular acreditavam que um entendimento aprofundado sobre esses micro-organismos poderia levar a fisiologia geral a compreender melhor os seres que, de acordo com certa perspectiva evolutiva, seriam mais complexos. Partilhando da ideia de que a evolução orgânica seguiria do básico em direção ao complexo ou que "as formas mais elaboradas de organização" se desenvolveriam de “tipos mais simples” (CLARKE; JACYNA, 1987, p. 20, tradução nossa), os autores filiados ao conceito de psicologia celular apostavam na existência de um percurso filogenético ou processo de continuidade - tanto fisiológico, quanto mental - que teria se iniciado nos "animais mais simples" e se completado no ser humano, "o tipo mais elevado e complexo" (WARDEN, 1940, p. 9, tradução nossa). A criatura humana, desse ponto de vista, representaria, como ponderou em 1835 o filósofo e naturalista francês Julien-Joseph Virey (1775-1846), “o animal mais perfeito de todos", a soma total das "estruturas inferiores, vertebradas e invertebradas" (VIREY, 1835, p. 387, tradução nossa).

No entanto, um dilema estabelecia-se, pois o indivíduo humano passava a ser visto simultaneamente como derivando da esfera animal (um animal entre outros) e como ocupante de uma posição superior (um animal favorecido no trajeto evolutivo). Por um lado, procurava-se encontrar um lugar para o ser humano no reino animal, "romper seu isolamento, preencher a lacuna entre ele e outros animais"; por outro, tentava-se assegurar ao homem, a despeito de sua condição 
animal, uma posição privilegiada na "hierarquia da natureza" (GODE-VON-AESCH, 1966, citado em CLARKE; JACYNA, 1987, p. 39, tradução nossa).

A tese de que existiria na natureza uma "escala ou cadeia de perfeição" (MARTINS, 1993, p. 95) é frequentemente associada ao naturalista francês JeanBaptiste Lamarck (1744-1829), embora ele não tenha sido o primeiro estudioso a propagar esse ponto de vista (SAPP, 2003). Consagrou-se, porém, a opinião de Lamarck de que haveria uma gradação no mundo animal, na qual estariam situados, em uma das extremidades da escala, "os animais mais perfeitos em todos os aspectos” e, em outra, “os mais imperfeitos” (LAMARCK, 1802, p. 14, tradução nossa). Em obra publicada em 1802 - Recherches sur l'organisation des corps vivans ("Investigações sobre a organização dos corpos vivos”) -, o eminente naturalista apresentou, em uma escala que iria do mais perfeito ao menos perfeito, a sua "série geral de animais". No topo da escala estaria o ser humano. Viriam então os mamíferos vivíparos, os pássaros, os répteis, os peixes, os moluscos, os anelídeos, os crustáceos, os aracnídeos, os insetos, os vermes, os radiários (classe de animais invertebrados), os pólipos e, por fim, os infusórios - "corpúsculos gelatinosos, transparentes, com uma forma extremamente simples, e contrácteis em todos os sentidos" (LAMARCK, 1802, p. 36, tradução nossa). ${ }^{59}$

Acreditando em uma tendência evolutiva linear que promoveria continuamente o aumento de complexidade e pautando-se pela suposição de que as criaturas mais "simples" (como as amebas e paramécios) teriam contribuído, no

\footnotetext{
${ }^{59}$ Ainda que tenha proposto um modelo serial, ordenando de maneira linear os grandes conjuntos de 'animais', Lamarck, cabe lembrar (MEGLHIORATTI; CALDEIRA; BORTOLOZZI, 2006), também reconheceu que, ao se comparar espécies pertencentes a um mesmo grupo, "a escala dos seres se apagava e se ramificava em um sem-fim de linhas divergentes, refratárias a qualquer classificação serial” (CAPONI, 2009, p. 73). Essas ramificações (como as que teriam dado origem, na visão lamarckista, ao condor e ao urubu, ou à girafa e ao antílope) seriam suscitadas, no entendimento do naturalista francês, pelas condições externas.
} 
processo evolutivo, com matrizes psicofisiológicas que, de alguma forma, teriam chegado às células dos seres mais “complexos”, os estudiosos da psicologia celular procuraram investigar a existência, em unicelulares, de rudimentos das funções psicológicas tradicionalmente atribuídas aos seres humanos, tais como volição, apreensão sensorial e capacidade de aprendizado. ${ }^{60}$ Considerando (e buscando comprovar experimentalmente) que os unicelulares seriam dotados de "sensações e percepções mesmo sem apresentar um sistema nervoso e órgãos sensoriais" (SCHLOEGEL; SCHMIDGEN, 2002, p. 618, tradução nossa), aqueles estudiosos tentavam determinar se a capacidade dos micro-organismos de responder aos estímulos externos deveria ser atribuída a uma consciência rudimentar ou, tão somente, a fatores mecânicos de caráter físico-químico.

O eminente biólogo Ernest Haeckel (1834-1919) - estudioso da anatomia comparada e embriologia, adepto de um evolucionismo estritamente físico-químico e fervoroso propagador das ideias darwinistas na Alemanha da segunda metade do século XIX - foi um dos cientistas que defendeu a tese da psicologia celular. Partilhando do ponto de vista de Virchow de que a célula seria dotada de grande autonomia, Haeckel julgava cientificamente válida, igualmente, a proposição de

\footnotetext{
${ }^{60}$ Paulo Dalgalarrondo, em seu esclarecedor Evolução do cérebro - Sistema nervoso, psicologia $e$ psicopatologia sob a perspectiva evolucionista chamou atenção para o fato de que a noção de "evolução linear progressiva" foi revista e criticada ao longo da primeira metade do século XX e que, no final da década de 1950, os paleontólogos e taxinomistas haviam "abandonado totalmente a perspectiva linear da evolução". Descrevendo o ponto de vista mais atual da biologia evolucionista, o autor comentou que cada organismo deve ser tomado como uma realidade singular: "As distintas espécies têm histórias evolutivas específicas e peculiaridades adaptativas também específicas em seus ambientes". 0 problema de qualificações como "inferior" e "superior" torna-se evidente quando se pensa, por exemplo, em algas e bactérias, organismos que, em termos de sobrevivência na Terra, deveriam ser considerados não como "inferiores", mas como "superiores" e mais bem adaptados, devido à sua "maior capacidade de sobrevivência na dimensão geológica do tempo". (No entanto, "poucos biólogos afirmarão que algas e bactérias são 'superiores' em relação a insetos, aves ou mamíferos”). Em suma, a natureza, à luz de uma perspectiva evolutiva mais recente, não teria "vocação para o melhor e o mais perfeito" e não possuiria "uma intencionalidade para algo presumivelmente superior ou para o progresso": "ideias como a de progresso, de 'seres superiores' e hierarquia valorativa na natureza são noções antropomorfas aplicadas quase sempre indevidamente à natureza” (DALGALARRONDO, 2011, p. 18).
} 
que ela conteria os germens de uma mente ou psiquismo: "afirmo enfaticamente que precisamos atribuir vida psíquica autônoma a cada célula orgânica individual” (HAECKEL, 1879, p. 46, tradução nossa). Convicto de que uma "forma primitiva de atividade psíquica" poderia ser identificada "até mesmo em animais menos desenvolvidos” (HAECKEL, 1895, p. 41, tradução nossa), o biólogo salientou que a existência de um sistema nervoso não seria pré-requisito para o fenômeno da sensação. A seu ver residiriam, em derradeira instância, nos "atributos universais do protoplasma” o suporte material ou as raízes “da sensação e do movimento" (HAECKEL, 1879, p. 106, tradução nossa).

A psicologia celular haeckeliana pautava-se por diversos estudos que teriam identificado, nos organismos unicelulares, "inquestionáveis sinais de vida psíquica”, tais como "sensação e volição", “movimento voluntário” e "sensação consciente (de pressão, luminosidade, calor)” (HAECKEL, 1879, p. 56, tradução nossa). A “psicologia e psiquiatria do futuro" - disciplinas que seriam, na visão do biólogo, um ramo da "fisiologia" ou ciência das "funções e atividades vitais dos organismos" - deveriam se dedicar a investigar, antes de tudo, "as funções psíquicas das células" (HAECKEL, 1895, p. 42-43, tradução nossa).

O fisiologista alemão Max Verworn (1863-1921), que teve Haeckel como um de seus professores, também se posicionou a favor da tese da continuidade mental entre unicelulares e multicelulares. Partilhando da concepção de que certo grau de atividade psíquica poderia ser identificado mesmo em organismos que não apresentam sistema nervoso, ele acreditava que a ciência da psicologia não deveria se limitar aos vertebrados e ao próprio ser humano, podendo estender-se legitimamente ao estudo da dinâmica psicológica das criaturas unicelulares (SCHLOEGEL; SCHMIDGEN, 2002). Ao descrever em 1889, na obra Psycho- 
physiologische Protistenstudien, experimentos em que submeteu certos seres unicelulares a variados estímulos (luminosos, térmicos, elétricos), o fisiologista ecoou, na introdução da obra, o pressuposto de que nos "organismos elementares" localizados "no nível mais inferior da vida" estariam presentes, ainda que de forma simplificada, "todos os fenômenos vitais que observamos nos organismos mais desenvolvidos", inclusive os de índole psicológica. Parecia-lhe até mesmo impossível alcançar um claro entendimento acerca do psiquismo humano caso o pesquisador se limitasse a investigar os seus (dos seres humanos) "complicados processos psicológicos" (VERWORN, 1889, citado em SCHLOEGEL; SCHMIDGEN, 2002, p. 626-627, tradução nossa). Por outro lado, o estudo da vida psicológica dos unicelulares certamente poderia, segundo o fisiologista, lançar novas luzes sobre o funcionamento mental humano.

Procedendo a uma ampla revisão das pesquisas acerca da biologia e "psicofisiologia" dos unicelulares, o célebre psicólogo francês Alfred Binet (18571911) publicou, em 1887, um estudo intitulado La vie psychique des microorganismes (“A vida psicológica dos micro-organismos”), objetivando preencher uma lacuna, posto que "o estudo dos seres microscópicos" estaria sendo "um pouco negligenciado pela psicologia comparada". Definindo os "micro-organismos" como as "formas mais simples da matéria viva” (BINET, 1887/1888, p. 87-88, tradução nossa), o psicólogo realçou que o fato de pertencerem "à escala mais inferior da vida" (p. 90, tradução nossa) não os tornava seres menos complexos do ponto de vista psíquico.

Ainda que os "proto-organismos" não apresentassem sistema nervoso, o protoplasma, realçou Binet, como que mimetizaria e executaria funções sensoriais e motoras, visto que a "massa indiferenciada de protoplasma" carregaria em si 
“todas as funções" que, em consequência de uma “divisão ulterior de trabalho" (BINET, 1887/1888, p. 113, tradução nossa), teriam se estruturalizado, nos multicelulares, na forma de rede nervosa organizada.

Recorrendo a diversas pesquisas experimentais, o psicólogo assinalou que "todos os micro-organismos" seriam dotados de "sensibilidade" (BINET, 1887/1888, p. 116, tradução nossa) e que, ao "se alimentarem", não o fariam sem critério, sabendo "muito bem escolher as partículas que querem absorver” (p. 139, tradução nossa). Se, por exemplo, a ameba, ao se deslocar, viesse a esbarrar em "um corpo estranho" que "não é uma substância nutritiva”, ela não o absorveria e o repeliria “com seus pseudópodos” (p. 140, tradução nossa); essa capacidade de “escolha”, ponderou o psicólogo, seria um "fenômeno capital” e poderia ser considerada como “critério das faculdades psíquicas” (p. 230, tradução nossa).

Bergson também reverberou, em suas análises filosóficas, a tese da psicologia celular. Ao examinar em 1907, em seu Evolution créatrice, o vínculo entre consciência e mobilidade corporal, o filósofo apontou, inicialmente, a “óbvia relação" que existiria entre as duas instâncias, realçando que a consciência dos “animais superiores" estaria atrelada a "alguns dispositivos cerebrais": "quanto mais o sistema nervoso se desenvolve, tanto mais numerosos e precisos se tornam os movimentos entre os quais ele pode escolher, e mais luminosa, também, é a consciência que o acompanha”. Mas, no entendimento do pensador francês, nem a mobilidade, nem a capacidade de escolha, nem mesmo a consciência teriam "por condição necessária a presença de um sistema nervoso", pois o aparato nervoso apenas direcionaria e amplificaria uma atividade primitiva e difusa já presente "na massa da substância organizada” (BERGSON, 1907/1984b, p. 588, tradução nossa). 
O sistema nervoso, enfatizou o filósofo, não criaria as funções de movimento e consciência, mas tão somente tornaria essas funções mais intensas ou as aperfeiçoaria. A capacidade de movimento e certa capacidade de reagir - “já vagamente consciente" - seriam fenômenos indissociáveis e se fariam presentes, até mesmo, no “organismo mais simples” (BERGSON, 1907/1984b, p. 589, tradução nossa).

Após esse breve resgate da psicologia celular, parece-nos possível compreender melhor por que Reich sentia-se à vontade para afirmar que um microorganismo como a ameba "percebe", mesmo sem contar com "quaisquer nervos sensoriais ou motores” (REICH, 1949/1973c, p. 117-118, tradução nossa), ou para asseverar que o “protoplasma” desse unicelular apresentaria "funções de expansão prazerosa e contração angustiosa” (p. 111 tradução nossa). Pois, do ponto de vista da psicologia celular - orientação teórica que certamente reverberou na produção reichiana -, certas funções sensoriais e 'psíquicas' estariam disseminadas, em diferentes graus de sofisticação, por todo o reino do vivo. ${ }^{61}$

Se os críticos da soberania cerebral, como vimos anteriormente, propugnavam um descentralismo anatomofisiológico, os adeptos da psicologia celular propunham, de forma mais ou menos enfática, um descentralismo mental que desapropriava o ser humano da pretensa ilusão de possuir um aparato psíquico radicalmente diferenciado. É nesse clima de combate às "figuras tradicionais de centralização” (STIEGLER, 2001, p. 22, tradução nossa) que Reich afirmou, sem

\footnotetext{
${ }^{61}$ Ao se referirem à presença, em seres unicelulares, de funções sensoriais e mnemônicas, chegando a enquadrá-las em certa atividade psicológica ou consciência primitivas, os adeptos da psicologia celular colocaram em xeque a própria noção de psiquismo. Não identificamos, porém, nos escritos dos autores da psicologia celular ou na obra reichiana a ideia de que esse 'psiquismo' dos micro-organismos conteria quaisquer rudimentos das complexas e criativas capacidades simbólicas típicas da vida mental humana.
} 
receios, que "toda matéria plasmática percebe, com ou sem nervos sensoriais" (REICH, 1949/1973c, p. 118, tradução nossa).

O autor, aliás, não apenas aderiu à tese de que haveria uma primitiva sensorialidade, como também desenvolveu o conceito de emocionalidade protoplasmática, pautando-se, como veremos a seguir, pelo fenômeno das correntes vegetativas.

\subsection{Emoção plasmática}

Comentamos, em outro momento, que Reich, ao tentar flexibilizar o encouraçamento de seus pacientes, deparou-se com a irrupção de uma série de fenômenos somáticos que tinham em comum a impressão subjetiva de que algo se movia ou passara a se mover no corpo como decorrência do processo terapêutico de desformatação da couraça. Vimos que o cientista denominou aquelas impressões de sensações plasmáticas, vegetativas, de órgão ou orgonóticas, e que, a seu ver, tais apreensões sensoriais estariam diretamente associadas à motilidade protoplasmática ou a função vegetativa humana. Focando a mais emblemática daquelas percepções - as sensações de corrente - vimos, ainda, que Reich não se limitou a averiguá-las do ponto de vista clínico e que as reexaminou durante seus experimentos com a bioeletricidade da pele.

A questão dos fluxos plasmáticos ou vegetativos se tornou "tão importante" para o cientista que ele decidiu estudá-los não apenas em seres humanos, mas também “microscopicamente em protozoários” (REICH, 1938/1979, p. 25, tradução nossa). O seu pressuposto era de que as correntes ou movimentações protoplasmáticas se fariam presentes tanto em unicelulares, quanto em 
multicelulares, e que a função vegetativa humana, como vimos anteriormente, nada mais representaria do que um aparato organizador da atividade plasmática do corpo como um todo.

No final de 1935, Reich, procedendo a investigações que logo o levariam ao estudo experimental dos bions, passou a observar pormenorizadamente o comportamento plasmático de alguns seres unicelulares (preocupando-se muito mais com as formas ou tipos de movimento, do que com os aspectos estruturais ou bioquímicos), inspirando-se, entre outros trabalhos, nas pesquisas dos protozoologistas Ludwig Rhumbler (1864-1939) e Max Hartmann (1876-1962). ${ }^{62}$ No contexto das investigações que submetiam seres unicelulares a diversos tipos de estímulos (químicos, térmicos, elétricos, luminosos), Rhumbler e Hartmann, como esclareceu um comentador reichiano, constataram que as amebas, em função da quantidade e qualidade dos estímulos, moviam-se em direção a eles ou os evitava, assumindo, nesse segundo caso, uma forma esférica do tipo “'fingindo-se de morto'”. Os pesquisadores também identificaram dois tipos de correntes plasmáticas nas amebas: fluxos de plasma em direção à superfície (que poderiam ser acompanhados por uma "aproximação ativa" do unicelular em relação a um dado objeto) e fluxos de plasma que seguiam da superfície em direção ao núcleo (denotando retração do micro-organismo). A dupla de cientistas também notou que a ameba, quando em repouso, apresentava "movimentos pulsáteis na forma de um ritmo alternado de expansão e contração" (SHARAF, 1983, p. 208, tradução nossa). Podia-se observar na ameba, em suma, tanto uma pulsatilidade, quanto fluxos plasmáticos.

\footnotetext{
${ }^{62}$ Hartmann interessou-se profundamente pela "morfologia comparativa de diferentes protistas", pelo "processo sexual em protozoários" e pela "análise e organização de seu núcleo" (FOKIN, 2004, p. 291292, tradução nossa).
} 
Em um estudo publicado em 1934, Reich sintetizou da seguinte forma aquelas pesquisas:

De acordo com Max Hartmann, o movimento da ameba depende diretamente do fluxo de plasma. Quando a ameba se move para frente, o plasma flui do centro para a periferia (formando assim o pseudópodo) [...]. Se a ameba for tocada, o fluxo de plasma revertese a si mesmo, isto é, o plasma se desloca do pseudópodo para o centro. É dessa forma que os pseudópodos se retraem. Se a ameba lançar vários pseudópodos e, por acaso, tocar em algo sólido, o plasma flui em direção ao pseudópodo que está em contato com o corpo sólido, enquanto os demais pseudópodos se retraem por esvaziamento de plasma. Quando ela se alimenta, o plasma sempre se move em direção à periferia. O plasma reage negativamente se afastando, em resposta a estímulos químicos, térmicos, elétricos ou luminosos. [...] A subestrutura do sistema de atividade vital da ameba nada mais é do que um fluxo vegetativo de plasma (REICH, 1934/1982a, p. 43, tradução nossa, grifo do autor).

Sempre preocupado em encontrar denominadores comuns entre distintos

fenômenos e níveis de funcionamento, o autor, associando suas pesquisas teóricas, clínicas, laboratoriais e epistemológicas, acreditou ter identificado um inédito e bastante peculiar ponto de ligação entre o comportamento dos seres unicelulares e a vida "emocional” humana:

A palavra 'emoção' significa, literalmente, 'mover para fora', 'empurrar para fora'. Assim, não só podemos como devemos tomar ao pé da letra a palavra 'emoção' quando nos referimos às sensações e movimentos. A observação, por meio de microscópio, de amebas vivas submetidas a discretos estímulos, revela inequivocamente 0 significado do termo 'emoção'. A emoção nada mais é, basicamente, do que um movimento plasmático. Os estímulos agradáveis eliciam uma 'emoção' no protoplasma, do centro em direção à periferia. Os estímulos desagradáveis, por sua vez, provocam uma 'emoção', ou melhor, uma 'remoção' do protoplasma, da periferia em direção ao centro do organismo. Essas duas direções básicas das correntes biofísicas plasmáticas correspondem aos dois afetos básicos do aparato 
psíquico: prazer e angústia. 0 movimento plasmático corporal e a correspondente sensação, como demonstraram os experimentos com o oscilógrafo, são funcionalmente idênticos (REICH, 1949/1973g, p. 356357, tradução nossa, grifo nosso).

Pautando-se por suas pesquisas experimentais, o autor insistiu que o sistema plasmático do ser vivo teria como propriedade básica a "MOTILIDADE ESPONTÂNEA" (REICH, 1952/1991b, p. 14, tradução nossa, grifo do autor). Por resultar, segundo o cientista, da coligação entre matéria e forças orgonóticas, a motilidade espontânea teria herdado o automovimento da energia orgone cósmica (pré-massa) e estaria, também, sob o efeito das determinações físico-químicas. Essa motilidade espontânea ou automovimento protoplasmático, com suas ações elementares de dilatação-retração e deslocamento por fluxos ou correntes, seria, na visão reichiana, a própria "emoção". Indivíduos humanos e organismos unicelulares seriam "funcionalmente idênticos" (apresentariam características comuns) no que se refere: a) "às excitações biológicas básicas", b) "às direções das correntes [plasmáticas]" (REICH, 1950/1990e, p. 19, tradução nossa).

Nessa perspectiva, criaturas unicelulares, desprovidas de sistema nervoso, seriam dotadas, elas também, de emoções no sentido reichiano do termo; mais que isso, teriam alguma percepção dessas “emoções” ou do próprio movimento protoplasmático: "Os impulsos e sensações são ações biológicas do organismo total. Estão presentes no sistema vital muito antes do desenvolvimento de um sistema nervoso organizado" (REICH, 1942/1989, p. 287, tradução nossa).

No âmbito dessa peculiar linha de investigação reichiana, os processos "emocionais" humanos, por estarem diretamente coligados à motilidade plasmático-vegetativa, aparentar-se-iam filogeneticamente às "formas de 
movimento dos moluscos e protozoários” (REICH, 1949/1973g, p. 398, tradução nossa, grifo do autor):

O sistema nervoso vegetativo é [...] um sistema plasmático contrátil, um órgão contrátil que permeia todo o organismo. Representa a 'ameba no organismo multicelular'. [...] 0 'animal no homem' [...] realmente existe como o elemento mais primitivo da natureza, que une o animal humano e a massa plasmática móvel (REICH, 1937/1982b, p. 125, tradução nossa, grifos do autor).

Procedendo a uma espécie de ‘despsicologização’ e enfatizando muito mais os aspectos dinâmicos do que os estruturais, o cientista ponderou, no estágio orgonômico de sua produção, que as "emoções" devem ser vistas como "funções plasmáticas, bioenergéticas", não como "funções mecânicas, químicas ou mentais" (REICH, 1949/1973h, p. 443, grifo do autor, tradução nossa). Mas não apenas as “emoções” receberam, por parte de Reich, uma inédita caracterização; o conceito de "expressão emocional" também foi reexaminado, pelo autor, em termos plasmáticos.

\subsection{Expressão emocional}

Reich sabia que precisaria definir com clareza seu conceito de emoção plasmática, para evitar confusões com as noções de emoção presentes "nos campos da psicologia moderna e da medicina”. Plenamente consciente de que o vocábulo em pauta é com frequência empregado como sinônimo “das palavras 'sentimento' e 'afeto"”, que remetem indubitavelmente ao “campo psíquico”, o autor, porém, viu um profundo significado, como observamos logo acima, no termo emoção - do latim ēmovēre: deslocar, mover para fora -, argumentando que a palavra teria 
expressado, originalmente, certa tentativa humana de dar concretude semântica ao "estado interno de 'motilidade’”. Mas, para além de questões etimológicas, o cientista estava convicto, a partir de sua experiência clínica e laboratorial, que o fenômeno da “emoção" não se restringiria à esfera psicológica e expressaria, antes de tudo, "estados de motilidade físicos e bioenergéticos" (REICH, 1952/1991b, p. 18-19, tradução nossa).

Além de estabelecer uma identidade entre a motilidade plasmática (em unicelulares e pluricelulares) e a “"emoção””, o autor também caracterizou tal motilidade interna como “'movimento expressivo”” (REICH, 1949/1973g, p. 359, tradução nossa). De acordo com a conceituação reichiana, o movimento expressivo do plasma (a emoção) se apresentaria externamente como expressão emocional. Movimento expressivo (a emoção ou motilidade plasmática interna) e expressão emocional (a configuração formal, exterior do movimento) seriam fenômenos interligados (REICH, 1949/1973h).

A pulsatilidade do plasma teria como motor, em outras palavras, uma energia biológica singular (denominada pelo autor, a partir de 1939, de energia orgone), se caracterizaria por pulsos e fluxos internos (o movimento expressivo emocional) e assumiria inevitavelmente uma forma exterior (a expressão emocional do movimento). Os movimentos plasmáticos internos (as emoções) poderiam ser, entre outras possibilidades, “rápidos ou lentos”, “intermitentes ou espasmódicos”. E um observador treinado conseguiria, segundo o autor, identificar o aspecto formal do estado plasmático (a expressão emocional), denominando-o, por exemplo, de “'rápido', 'voraz', ‘hesitante', ‘estagnado’” (REICH, 1952/1991b, p. 15-16, tradução nossa). 
No ser humano as sensações de órgão (a exemplo das sensações de corrente) nada mais seriam do que a tradução psíquica dos diferentes estados orgonóticos da motilidade plasmática. Na perspectiva reichiana, tais sensações representariam a “percepção subjetiva da 'excitação plasmática' objetiva'” (REICH, 1945, p. 1, tradução nossa, grifo do autor). A linguagem informal ou cotidiana conteria, segundo o cientista, claras indicações dessa apreensão psíquica, do tipo e grau de motilidade plasmática:

Os estados psíquicos de angústia e prazer são experienciados como estados específicos de motilidade. Experienciamos o prazer, de imediato, como um movimento de expansão, de abertura (widening); a angústia, por sua vez, é experienciada como contração 'encolhimento' no medo, 'esconder-se dentro de si mesmo' na vergonha, 'quase explodindo' ou 'agitação interna' nos estados agudos de angústia. Gostaria de salientar que não estou me referindo à qualidade 'prazerosa' ou 'desprazerosa' de dois estados perceptivos, mas tão somente à sensação de motilidade. Na linguagem coloquial a palavra 'movimento' (motility) também expressa, de forma direta, o que realmente acontece no organismo: a pessoa se sente 'mexida' ('moved'). Esse estar mexido ('being moved') pode ser forte ou fraco, prazeroso ou desprazeroso, mas é sempre movimento (REICH, 1952/1991b, p. 14-15, tradução nossa).

Ao se referir, na citação acima, ao prazer (em seres humanos) que é vivenciado como um movimento de expansão-abertura e à angústia que é experienciada como retração-encolhimento, o autor exemplificou didaticamente o seu conceito de sensação de órgão, plasmática, vegetativa ou orgonótica. Vimos examinando, ao longo deste trabalho, esse conceito e, agora, munidos da teoria reichiana das 'emoções', voltaremos a ele, averiguando-o dessa feita no quadro da terapêutica orgonômica. Para tanto, tomaremos como referência, uma vez mais, as 
sensações de corrente, uma das mais características percepções, de acordo com a perspectiva reichiana, das sensações plasmático-vegetativas.

\subsection{As sensações de corrente no contexto terapêutico}

Como comentamos anteriormente, entre as percepções plasmáticas ou de órgão chamou particularmente a atenção do autor (e de alguns de seus pacientes) as sensações de corrente, as quais se faziam excepcionalmente vívidas quando se apresentavam na forma de "correntes genitais". Em uma nota enxertada em 1945 em seu Charakteranalyse, o cientista esclareceu que, durante o trabalho orgonoterápico de dissolução da couraça, “todos os reflexos biológicos e movimentos" tenderiam a convergir para o "reflexo orgástico total" e suas "sensações de correntes orgonóticas no genital". Seria esse processo que, no entendimento do autor, permitiria “a instauração da potência orgástica” (REICH, 1933/1973a, p. 136, tradução nossa, grifo do autor).

De acordo com os relatos clínicos reichianos, o paciente, ao longo da orgonoterapia, gradativamente experienciava, como decorrência da flexibilização de seu encouraçamento, movimentos reflexos ou "contrações vegetativas isoladas" em várias partes do corpo; na fase final do processo aquelas contrações, segundo o autor, integravam-se, produzindo "um único reflexo corporal total”. O cientista afirmou ter identificado esse movimento reflexo global em 1935, denominando-o de "reflexo do orgasmo" (REICH, 1938/1979, p. 20, tradução nossa). ${ }^{63}$

\footnotetext{
${ }^{63}$ Reich relatou que, com a "descoberta" do reflexo do orgasmo em 1935, seu método terapêutico começou a se deslocar do trabalho com as defesas caracteriais para o "corpo" (REICH, 1949/1973g, p. 355 , tradução nossa, grifo do autor).
} 
Para Reich, o reflexo do orgasmo representava, excetuando-se o fenômeno da respiração, "a manifestação mais importante de movimento no reino animal" (REICH, 1949/1973g, p. 365, tradução nossa) e indicava a presença de uma resposta corporal unitária ou forte coesão organísmica. Na experiência orgástico-genital propriamente dita, os indivíduos reduzir-se-iam a "uma massa plasmática pulsante" (REICH, 1942/1989, p. 348, tradução nossa) e vivenciariam as sensações de corrente em "sua forma mais intensa" (REICH, 1990c, p. 51, tradução nossa).

Interessante observar que, para o autor, não apenas a básica sensorialidade e o fenômeno da 'emoção', mas também o 'orgasmo’ ocorreriam nos “organismos biológicos mais primitivos”, expressando-se, nesses micro-organismos, diretamente por “contrações plasmáticas” (REICH, 1942/1989, p. 348, tradução nossa). Reich acreditava, ainda, que a experiência orgástico-genital humana, por promover um intenso contato com as sensações de corrente, poderia levar o indivíduo a perceber a si mesmo como parte da natureza ( $\mathrm{REICH}, 1935 / 1973 d)$ e até mesmo sugerir-lhe o "fato biológico" de que "o homem é, fundamentalmente, um animal" (REICH, 1943/1946b, p. 286, tradução nossa, grifo do autor), mais precisamente, um animal protoplasmático. Pois o autor era da opinião de que os seres humanos, por mais que se esforçassem, não poderiam jamais escapar de sua "organização plasmática”, nem de sua "animalidade” (no sentido de condição animal, não de brutalidade), nem de seu “corpo”, nem do "sentimento orgástico” (REICH, 1990f, p. 40 , tradução nossa).

O sujeito encouraçado teria, no entanto, perdido essa mobilidade plasmática. Sem conseguir estabelecer conexão direta com seus pulsos-fluxos plasmáticos, o indivíduo cronicamente encouraçado passaria a construir, de acordo com a leitura reichiana, contatos substitutivos (artificiais, não imediatos) com o 
mundo. Coagido pela educação autoritária, ele incorporaria desde criança, como vimos anteriormente, traços de caráter bem-vistos pela ideologia dominante, à custa, porém, do amortecimento de sua vitalidade vegetativa, empobrecimento das capacidades crítico-intelectuais e distanciamento perceptivo das correntes orgástico-genitais (REICH, 1935/1973d). Por isso, Reich acreditava que sua orgonoterapia precisaria, para lidar com tão danoso encouraçamento, alcançar as “profundezas biológicas", ou melhor, o "sistema plasmático" ou “núcleo biológico do organismo" (REICH, 1949/1973g, p. 358, tradução nossa, grifos do autor).

A orgonoterapia, para Reich, olharia de uma forma fundamentalmente nova para o ser humano, pois essa técnica terapêutica teria tornado possível abandonar definitivamente “o campo da psicologia, inclusive o da psicologia 'profunda'”, ultrapassar a esfera da "fisiologia dos nervos e músculos” e alcançar, enfim, o “terreno das funções protoplasmáticas". Essa tentativa de entender a especificidade das funções plasmáticas e intervir diretamente nelas teria, no entendimento do autor, decisivas implicações "teóricas e práticas", pois uma abordagem como a orgonoterapia não procuraria "trabalhar meramente com conflitos individuais" ou examinar as particularidades dos encouraçamentos pessoais, mas sim, alcançar tecnicamente “o organismo vivo em si mesmo" (REICH, 1949/1973g, p. 358, tradução nossa, grifo do autor).

Nessa nova “compreensão funcional” do ser humano, o "bioaparato” passaria a ser visto, segundo o autor, como constituído por um "centro bioenergético ou NÚCLEO” (representado, nos “animais superiores”, pelo “aparato ganglionar autônomo") e uma "periferia bioenergética" ou "membrana de superfície do organismo" (REICH, 1950d, p. 121, tradução nossa, grifo do autor). Reich insistiu que esse modelo biofísico nada teria a ver e não deveria, em absoluto, ser 
confundido com os modelos freudianos de aparelho psíquico: "há somente um ponto de ligação entre os dois esquemas teóricos - o 'id’ da teoria psicanalítica, no qual termina o reino da psicologia e começa o da biofísica, para além da psicologia” (REICH, 1949/1973h, p. 403, tradução nossa, grifos do autor). Pois a aplicação do "método psicológico de pensamento" ao "funcionamento biológico plasmático” (REICH, 1950d, p. 121, tradução nossa) representaria, no entendimento do autor, um grave erro epistemológico.

Tais ponderações levam a pensar a respeito do papel do psiquismo no contexto das pesquisas orgonômicas reichianas. Tentemos, então, explorar brevemente essa questão.

\subsection{Sensação, autopercepção e consciência}

Nossas pesquisas puderam aferir, até o momento, que o autor, referindo-se ao amplo campo do vivo, propôs a existência de uma primitiva sensorialidade que derivaria da excitação ou pulsatilidade orgonótica e indicaria a condição emocional (tipo e grau de movimento protoplasmático) do organismo. Esses aspectos se associariam, em seres humanos, a outros dois: a sensação como dado imediato da consciência e como ingrediente básico do psiquismo. Examinamos anteriormente o entendimento do autor sobre a imediaticidade da apreensão sensorial e fizemos breves menções a sua tese de que a sensorialidade plasmática desempenharia importante papel no funcionamento psicológico humano. Averiguaremos agora, com mais detalhes, essa coligação entre sensação plasmática e dinâmica psíquica.

Vimos, em outro momento, que Reich caracterizou o psiquismo como a esfera das "sensações, percepções e ideias" (REICH, 1952/1991b, p. 3-4, tradução 
nossa), considerando, porém, que seu eixo central seriam as sensações: “É necessário limitar o conceito de ‘psíquico’ à esfera das sensações e, assim, utilizálo para descrever apenas a experiência subjetiva dos processos vitais objetivos" (REICH, 1950/1990e, p. 11, tradução nossa). Tais processos objetivos remeteriam, como observamos há pouco, à motilidade emocional (o movimento orgonóticoplasmático) do indivíduo.

$\mathrm{Na}$ literatura reichiana, especialmente em textos do período orgonômico, encontramos, porém, não apenas considerações sobre a sensorialidade plasmática, mas também sobre o papel, na vida humana, da percepção e consciência. Cabe examinar, assim, possíveis relações, no trabalho do autor, entre esses três conceitos.

Averiguando-se certo conjunto de escritos reichianos (REICH, 1944/1991a, 1949/1973c, 1949/1973h, 1996b, 1999), infere-se que, se a sensação, para o cientista, representava essencialmente uma sinalização da pulsatilidade plasmática, a função ou “sistema perceptivo" (REICH, 1999, p. 192, tradução nossa) apontava, por sua vez, para o próprio mecanismo de captação dos estímulos. Esse primitivo sistema de rastreamento (a função perceptiva) apreenderia (na forma de sensações) algumas modulações plasmáticas e determinados estímulos externos. Assim, sensação e percepção representariam, no que tange à motilidade plasmático-vegetativa, duas faces da mesma moeda. ${ }^{64}$

No entendimento de Reich, certa capacidade perceptiva e a sensorialidade plasmática deveriam ser vistas como propriedades básicas da matéria viva que se fariam presentes em toda e qualquer criatura vivente, não apenas em indivíduos

\footnotetext{
${ }^{64}$ Prova disso é o fato de o autor ter se referido, ainda que com frequência menor, à "percepção sensorial" (REICH, 1949/1973c, p. 41, tradução nossa).
} 
humanos ou em seres dotados de sistema nervoso. Mas, quando o autor se referia especificamente ao psiquismo humano, ora encontramos menções ao elemento rastreado - as sensações (especialmente as plasmáticas) -, ora ao próprio mecanismo de rastreamento, ou seja, a "autopercepção ou percepção de funções plasmáticas biofísicas, objetivas” (REICH, 1949/1973h, p. 433, tradução nossa).

O estudo da faculdade perceptiva e da consciência representava, na visão de Reich, uma tarefa tão desafiadora, quanto complexa. Em sua opinião, a pesquisa científica acabaria se havendo, cedo ou tarde, com um dos "mais difíceis e obscuros" problemas: a "função da autopercepção no plasma vivo". Essa capacidade perceptiva (que seria, como vimos anteriormente, indissociável da pulsatilidade orgonótica do ser vivo) e, também, a própria consciência humana representariam um intrincado enigma: “eu, pessoalmente, encaro [o problema da consciência] como o mais difícil e decisivo que se apresenta a toda ciência natural” (REICH, 1999, p. 192, tradução nossa).

Ainda que tivesse cogitado sobre certa capacidade percepto-sensorial que seria imanente a todos os seres vivos, Reich deu a entender que a instância da consciência - ou o "estar "consciente' de si mesmo" - seria uma "função superior" específica das “espécies mais desenvolvidas” (REICH, 1949/1973h, p. 442, tradução nossa). O cientista, entretanto, não esclareceu, até onde temos conhecimento, por que considerava tais espécies como dotadas de consciência, ou mesmo que espécies seriam essas. Ele se esforçou, porém, em esboçar algumas teses sobre o funcionamento da consciência em seres humanos.

Em uma esclarecedora anotação em seu diário, datada de 25 de janeiro de 1947, o cientista ponderou que a consciência representaria a "expressão máxima da unidade organísmica" ou o "ato" que integraria “todas as sensações de órgão 
em um Eu” (REICH, 1999, p. 382, tradução nossa, grifo do autor). Nesse sentido, a consciência atuaria como instância coordenadora e organizadora dos diversos gêneros de sensações plasmáticas que se fariam presentes ao indivíduo, continuamente.

No mesmo apontamento de 1947, o autor indicou duas outras e interdependentes características da consciência. Na visão reichiana, a instância da consciência promoveria os "limites do Eu” e, também, a “unidade entre o Eu e o universo", de modo que esses dois "estados" ou condições - noção de contorno e noção de fusão - se associariam "em um único estado". Dar-se-ia uma "dialética do Eu”, posto que o Eu se apresentaria, ao mesmo tempo, “como separado do todo e parte do todo": "Não posso me experienciar como um Eu, se não me diferencio do universo ao mesmo tempo em que experiencio a mim mesmo como parte dele" (REICH, 1999, p. 382, tradução nossa, grifo do autor). Diferenciação (noção de delimitação em relação ao mundo) e integração (noção de unidade com o mundo) seriam, na experiência do indivíduo, funções indissociáveis, mediadas, ambas, pela instância da consciência.

Em um texto intitulado “The schizophrenic split”, publicado em 1949 na terceira edição de seu Character analysis, Reich, ao descrever o tratamento orgonoterápico de uma paciente que chegara até ele com o diagnóstico de esquizofrenia, aventurou-se a realizar uma "primeira tentativa orgonômica" de abordar - valendo-se do caso clínico em apreço, de sua experiência no campo terapêutico e das formulações da Orgonomia - "o problema da consciência e da autopercepção” (REICH, 1949/1973h, p. 442, tradução nossa). Nesse estudo, ele apontou o caráter sintético e unificador da consciência, mencionado logo acima, e discorreu, entre diversos outros temas, sobre a fase inicial da vida do bebê, 
período em que, na visão reichiana, começaria a se desenvolver paulatinamente a consciência ou integração dos “inúmeros elementos da autopercepção em uma experiência unitária de SI MESMO (SELF)" (p. 442, tradução nossa, grifo do autor). ${ }^{65}$ Dado seu pressuposto de que haveria uma função perceptiva imanente à matéria viva ou à pulsatilidade bioenergética, o autor sentia-se à vontade para se referir a uma incipiente percepção plasmática que operaria desde a "vida uterina” (p. 445, tradução nossa). Esse gênero de percepção não deveria, entretanto, ser confundido com a consciência, instância que evolucionaria gradualmente, integrando, pouco a pouco, sensações relacionadas aos diversos órgãos e sistemas da criança:

\begin{abstract}
Os movimentos do recém-nascido não estão integrados em UMA função global e, consequentemente, não há qualquer 'propósito' ou 'significado' nos movimentos. É fato que as reações de prazer e angústia já estão nitidamente formadas, mas ainda não se pode encontrar quaisquer movimentos coordenados que indiquem a presença de ampla consciência e de noção de si mesmo (self-awareness). Precisamos assumir que no recém-nascido a autopercepção já existe e funciona amplamente, mas não de maneira coordenada, unitária. As mãos se movem autonomamente, assim como os olhos, os quais, de início, ainda não estão focados nos objetos [...]. Durante os primeiros meses de vida, desenvolve-se gradualmente a coordenação dos movimentos isolados e independentes (REICH, 1949/1973h, p. 444, tradução nossa, grifos do autor).
\end{abstract}

\footnotetext{
${ }^{65}$ Reich considerava como extremamente importante, para a saúde do indivíduo, o processo integrativo da percepção que teria início, a seu ver, nos dois ou três primeiros meses de vida (REICH, 1996b). Interessado na prevenção do encouraçamento de crianças e adolescentes, o autor vislumbrou, no período 1939-1949, a possibilidade de um trabalho profilático de caráter multidisciplinar, possibilidade essa que ganhou concretude em 16 de dezembro de 1949 na forma de um projeto denominado Orgonomic Infant Research Center (OIRC). O OIRC foi pensado como um amplo centro de pesquisas (REICH, 1984b) que, em sua formulação inicial, pretendia se dedicar, como explica uma comentadora da obra reichiana, ao "atendimento de 'crianças saudáveis' que oferecessem elementos para o estudo da saúde, sobretudo dos recém-nascidos" (MATTHIESEN, 2003, p. 180). Partindo do pressuposto de que seria preciso delimitar, com clareza, o conceito de “criança saudável'” (REICH, 1984a, p. 7, tradução nossa), quarenta profissionais foram selecionados para participar do projeto, entre eles, médicos, enfermeiras e assistentes sociais, além dos pais. A importância do processo de integração perceptiva nos bebês e diversas outras formulações discutidas no OIRC foram republicadas em 1984 no livro Children of the future (REICH, 1984a), obra que contém, ainda, outros estudos de Reich, redigidos em diferentes períodos de sua obra, a respeito da infância e adolescência.
} 
O recém-nascido - como comentou o autor por volta de 1949-1950 em um debate com seus alunos - mostrar-se-ia "não integrado, mas não desintegrado" (REICH, 1996b, p. 52, tradução nossa). ${ }^{66}$ Os movimentos corporais, ainda que não sincrônicos, seriam, no entendimento reichiano, efetivamente percebidos ou autopercebidos pelo bebê, e essas sensações de órgão se encaminhariam, na ausência de condições patológicas, para uma integração no plano da consciência ou do "funcionamento global" (p. 54, tradução nossa). Um exemplo desse processo de integração dar-se-ia quando a criança passa a observar, focando a visão, o movimento de sua própria mão. Esse tipo de coordenação representaria, na perspectiva reichiana, o surgimento de um importante contato (termo que o autor considerava bastante apropriado nesse contexto) entre duas ações distintas (olhos focando e mão em movimento), contato esse que influenciaria o "organismo como um todo", de modo que o ato de olhar passaria doravante a implicar o indivíduo em sua totalidade e não apenas seu sistema visual. Além disso, a criança gradualmente tomaria consciência "do fato de que ela enxerga" (p. 61, tradução nossa), estabelecendo-se assim um vínculo entre a ação somática (o olhar focado) e alguma noção psicológica da realização de tal ação:

Ao nascer, a criança é uma unidade orgânica, mas [...] as funções específicas no interior dessa unidade não estão conectadas. [...] Cada uma segue seu próprio caminho. Em determinado momento começa a coordenação dos movimentos. Os movimentos estabelecem contato entre si. Desenvolve-se então a percepção desses contatos ou a

\footnotetext{
${ }^{66}$ A desintegração das funções psíquicas em certos tipos de esquizofrenia seria justamente o negativo, na visão reichiana, do gradual processo de integração perceptiva do recém-nascido. Evitando o conceito psicológico de regressão, Reich preferia ver, em determinados casos de esquizofrenia, a permanência, no adolescente ou no adulto, de uma disfunção que teria sido construída e vivenciada desde a mais tenra idade: a precária ou pouco consistente coesão das funções perceptivas no plano da consciência. Desempenharia importante papel, nessa patologia, o fato de os olhos, segundo Reich, nem sempre participarem coordenadamente da experiência global do sujeito, por se ausentarem ou se desconectarem defensivamente (REICH, 1949/1973h, 1996b).
} 
consciência deles. Dessa forma, o organismo como um todo se torna uma unidade mais completa. O organismo como um todo vai se fortalecendo à medida que expande, não apenas em seu crescimento físico, mas em sua consciência desse crescimento. A consciência se amplia. [...] Consciência de si mesmo (REICH, 1996b, p. 62, tradução nossa). ${ }^{67}$

Haveria, assim, vinculação direta entre a sensorialidade plasmática e o desenvolvimento dos diversos órgãos da criança. A massa das autopercepções seria gradualmente integrada no âmbito da consciência, a qual, ao se desenvolver e expandir, reconfiguraria o próprio ato perceptivo: “consciência é uma função da autopercepção em geral, e vice-versa” (REICH, 1949/1973h, p. 442, tradução nossa, grifo do autor). O bebê experenciaria de forma imediata suas percepções plasmáticas, mas a integração dessas percepções, como vimos acima, dar-se-ia paulatinamente no plano da consciência. A ação dotada de propósito, direcionada, seria resultado, na criança pequena, desse processo de desenvolvimento da consciência. No adulto ocorreria, todo o tempo, uma estreita conexão entre autopercepção - “uma parte essencial do processo da vida” (REICH, 1948/1973e, p. 98, tradução nossa, grifo do autor) - e consciência:

\footnotetext{
${ }^{67} \mathrm{O}$ autor, como se pode notar na citação acima, atribuía grande autonomia à função perceptiva. Esse posicionamento faz-se ainda mais evidente em seu entendimento orgonômico sobre a relação corpomente. De acordo com as pesquisas reichianas, o ser humano seria dotado, desde o momento da concepção, de um estrato bioenergético profundo, caracterizado pela pulsatilidade orgonótica. Durante a gestação, esse amplo estrato começaria a se ramificar, porém sem se extinguir, dando origem a dois outros: um ramo "somático" (associado à formação dos diferentes órgãos) e um ramo "emocional" (associado à coordenação das diversas autopercepções); este último limitar-se-ia, no estágio pré-natal, às "percepções de prazer e desprazer". Por ocasião do nascimento, "soma e psique" já se comportariam nitidamente como dois ramos paralelos, ainda que interdependentes. Os órgãos e sistemas continuariam, então, se desenvolvendo e, aos poucos, estabelecendo coordenações entre si, em direção a uma integração cada vez mais consistente. Ao mesmo tempo, as percepções de prazer e desprazer começariam a se diversificar e se sofisticar, tomando a forma das "funções básicas de prazer, angústia e raiva" e de várias outras "funções de percepção" (REICH, 1944/1991a, p. 34, tradução nossa). Foge de nossos propósitos, aqui, examinar essas asserções reichianas e contrastá-las com outras teorias sobre o desenvolvimento do feto, do recém-nascido e da criança pequena. No escopo da presente tese cabe realçar, entretanto, que as formulações do autor a respeito da conexão corpo-mente estão diretamente associadas ao seu entendimento da percepção como uma operação básica imanente ao protoplasma (ou, em termos reichianos mais precisos, um protoplasma orgonoticamente excitado).
} 
[...] o grande problema referente ao funcionamento da consciência pode, muito provavelmente, ser solucionado por meio do estudo detalhado do processo de integração no recém-nascido. A consciência afigurar-se-ia, então, como a soma total de todas as integrações, de todos os contatos dentro do organismo e do contato desse organismo, internamente integrado, com o mundo separado e externo a ele (REICH, 1996b, p. 63, tradução nossa). ${ }^{68}$

Sintetizando o entendimento reichiano sobre a sensorialidade plasmática, o fenômeno perceptivo e o campo da consciência, pode-se dizer que o autor: a) apontou como núcleo do aparelho psíquico ou da consciência, as sensações ou percepções de órgão; b) concebeu a consciência como uma esfera que, por meio de uma espécie de força coesiva, integraria as diversas sensações plasmáticas; c) viu na consciência, também, uma instância promotora da diferenciação e da unidade com o mundo exterior.

\subsection{Considerações gerais}

Como pudemos observar, Reich ecoou, especialmente na fase norteamericana de sua produção, teses oriundas da psicologia celular, a vertente

\footnotetext{
${ }^{68}$ Ainda que Reich tenha continuamente apontado, no decorrer de sua produção, os fatores culturais que, a seu ver, impediriam nas sociedades autoritárias o pleno exercício da pulsatilidade emocional (plasmática) de crianças, adolescentes e adultos, chama a atenção, em algumas de suas análises orgonômicas sobre a integração percepto-sensorial ou sobre a dinâmica do psiquismo, o fato de os vetores internos (ou bioenergéticos) ganharem muito mais ênfase do que as determinações sociais. Não nos cabe avaliar profundamente, aqui, as razões desse posicionamento reichiano. Lembramos apenas que o autor, distanciando-se da perspectiva freudo-marxista que, no final da década de 1920 e primeira metade da década de 1930, orientara seus estudos sobre a interface entre constituição psíquica e dimensão político-cultural, não mais recorreu, em suas pesquisas orgonômicas, à crítica sociológica marxista e à teoria freudiana. Sem jamais deixar de reconhecer a importância das ideias de Freud e Marx para o desenvolvimento de sua obra, Reich, contudo, considerava ultrapassadas as correntes psicanalíticas e as orientações políticas marxistas, como se observa em uma carta que ele enviou ao amigo A. S. Neill, em 24 de julho de 1952: "[...] tanto o marxismo, quanto o freudismo são gatos mortos, mesmo que ainda façam barulho por mais uns poucos séculos". Um "tipo inteiramente novo de pensamento" (PLACZEK, 1981, p. 353, tradução nossa, grifo do autor) far-se-ia necessário, e Reich acreditava que as proposições científicas e epistemológicas da Orgonomia poderiam contribuir significativamente para uma inovadora e afirmativa visão de mundo em relação à vida.
} 
investigativa que, correndo paralela ao estudo do cérebro e à psicologia experimental, também se propôs a contribuir para o entendimento das operações percepto-sensoriais e da mente humana, buscando as matrizes da atividade psíquica em propriedades protoplasmáticas básicas que se fariam presentes tanto em criaturas unicelulares, quanto em cada célula do organismo pluricelular. Deixando de lado "organismos mais desenvolvidos, como sapos, coelhos ou cães" e colocando o foco "na célula ou em 'organismos elementares'”, os adeptos da psicologia celular puseram-se no encalço das "propriedades comuns a todos os seres vivos" (SCHLOEGEL; SCHMIDGEN, 2002, p. 616, tradução nossa). Reich, como vimos, pode ser considerado um continuador direto desse programa de pesquisa, embora não tenha chegado a propor, como comentamos anteriormente, que os organismos unicelulares fossem dotados de uma vida psíquica tão complexa e elaborada como a dos seres humanos.

O autor fez claras referências, porém, a uma classe de sensações - as sensações vegetativas ou orgonóticas - que acompanhariam o estado, condição ou grau de motilidade protoplasmática do organismo e se fariam presentes tanto em criaturas unicelulares, quanto em organismos pluricelulares. Sob a ação da pulsatilidade orgonótica, ocorreriam dilatação-encolhimento e fluxos plasmáticos que seriam acompanhados, em todo ser vivo, de alguma ressonância sensorial.

Nesse contexto, recuperamos a tese reichiana de que a motilidade plasmática (e suas correlatas sensações) representaria o principal fator comum a todas as criaturas vivas, de modo que, no caso dos seres humanos, o contato com as sensações plasmático-vegetativas teria potencial, na visão do autor, para reconectar o indivíduo às suas origens filogenéticas naturais. 
Vimos também que Reich, fundamentando-se em seus estudos clínicos e experimentais, atribuiu ao termo emoção o novo significado de movimento plasmático e estabeleceu uma diferenciação entre motilidade protoplasmática (a ‘emoção’ em si mesma) e expressão emocional (a manifestação externa e periférica de tal motilidade). Tratando-se de humanos, captar a expressão emocional de outrem significaria, na perspectiva reichiana, apreender-lhe o estado de motilidade plasmática.

Pudemos notar, ainda, que o autor concebeu a sensação e a percepção como dois ângulos de uma primitiva capacidade da matéria viva, e considerou a consciência humana como um sistema que coordenaria/integraria a sensorialidade plasmática e, assim, contribuiria para a construção de ações intencionais.

Ingrediente essencial da consciência, a sensação plasmática também desempenharia, segundo o autor, importante papel na produção humana de conhecimento, como veremos no próximo capítulo. 


\section{SENSAÇÃO E CONHECIMENTO}

“[...] nenhuma proposição científica foi formulada se não por meio da sensação. Todas as proposições científico-naturais são, assim, necessariamente afetadas pela sensação."

(W. Reich, 13.08.1943 - American Odissey. Letters and journals, 1940-1947). 
Examinamos, no capítulo anterior, a tese reichiana de que certa classe de sensações (as sensações vegetativas, de órgão, plasmáticas ou orgonóticas) nasceria das “emoções” (os pulsos e correntes plasmáticas). Averiguaremos, agora, as inter-relações, sugeridas por Reich, entre as sensações plasmático-vegetativas e a produção humana de conhecimento, inclusive o saber científico. Para tal, precisaremos recorrer a dois elementos-chave da obra do autor: a noção de couraça, sobre a qual já tecemos algumas apreciações, e o conceito de organização biopsíquica, que recuperaremos neste capítulo.

Como teremos oportunidade de observar, o autor defendeu a tese de que haveria uma organização ou estrutura biopsíquica que determinaria a maneira pela qual o indivíduo lê ou interpreta suas próprias sensações vegetativas. Essa leitura, interpretação ou modelação da experiência sensorial poderia assumir, na visão reichiana, tons mais ou menos mecanicistas, espiritualistas ou 'funcionais' e repercutiria diretamente em sua vida intelectual.

As raízes filosóficas desse conceito de organização remetem, como notaremos no presente capítulo, à tentativa de Lange de atualizar, de um ponto de vista científico-natural, certas proposições kantianas acerca da construção do conhecimento. As estruturas apriorísticas responsáveis pela constituição do conhecimento deveriam ser buscadas, de acordo com a perspectiva langeana, muito mais na organização psicofisiológica do sujeito do que nos confins da razão.

Tomando como ponto de partida essas formulações do filósofo alemão, procuraremos demonstrar que Reich, inspirando-se no conceito langeano de organização, caminhou em direção a uma teorização própria a respeito da 
produção de conhecimento e que essa teorização, em sua forma mais elaborada, adotou como elemento-chave de análise o conceito de sensação plasmática. Para tanto, examinaremos inicialmente algumas asserções reichianas de índole psicanalítica e de orientação freudo-marxista, prévias à noção de organização biopsíquica, em que o autor trabalhou a ideia geral de que a estrutura de caráter atuaria como um sistema regulador das dimensões emocional, erótica e intelectual do indivíduo. Chegaremos, a partir daí, à tese, apresentada pelo cientista em seu período orgonômico, de que a humanidade estaria basicamente divida em três tipos de organizações ou estruturas biopsíquicas: a estrutura mecanicista, a estrutura mística e a estrutura desencouraçada. Verificaremos, então, a postulação reichiana de que cada uma dessas estruturas conduziria a um específico posicionamento diante das sensações plasmáticas: negação ou distanciamento na estrutura mecanicista, distorção patológica na estrutura mística, e uma atitude acolhedora e afirmativa na estrutura desencouraçada.

Retomaremos, por fim, os estudos reichianos acerca do papel da sensação no trabalho dos profissionais da ciência. Nesse contexto, notaremos que Reich, em suas reflexões epistemológicas, propôs que a sensação plasmática poderia representar importante instrumento no trabalho investigativo de um cientista e que o grau de proximidade do cientista em relação às suas próprias correntes vegetativas repercutiria diretamente nos resultados da pesquisa.

\subsection{Sensação plasmática e visão de mundo}

A noção reichiana de organização ou estrutura biopsíquica substancializa, como veremos mais adiante, as conexões que o autor estabeleceu, especialmente 
no estágio orgonômico de sua produção, entre sensorialidade plasmática e produção de conhecimento. De acordo com o cientista, haveria na sociedade contemporânea três formas gerais de estruturação, como mencionamos brevemente logo acima: a estrutura mecanicista, a estrutura mística e a estrutura não encouraçada. As duas primeiras padeceriam de uma intensa couraça, o que não ocorreria com a terceira.

A diferenciação entre indivíduo encouraçado e desencouraçado é central na produção de Reich e a base a partir da qual ele abordou os vínculos entre sensorialidade plasmática e produção de conhecimento. Assim, cabe retomar, antes de tudo, algumas apreciações gerais do autor sobre tal diferenciação.

\subsubsection{Couraça e subjetividade}

Em diversos momentos e a partir de diferentes ângulos, Reich defendeu a tese de que a couraça influenciaria ou moldaria, de maneira determinante, a subjetividade do sujeito. Para o cientista, a presença ou não de encouraçamento seria algo crucial na existência do indivíduo, pois, a seu ver, o "organismo encouraçado" perceberia e compreenderia a si mesmo e ao seu entorno de maneira "essencialmente distinta" da do "indivíduo desencouraçado" (REICH, 1949/1973c, p. 56, tradução nossa, grifos do autor).

Como mencionamos anteriormente, o sujeito encouraçado, segundo as pesquisas reichianas, apresentaria um rígido bloqueio ou sérias disfunções no que concerne à mobilidade de suas "correntes plasmáticas" (REICH, 1990c, p. 31, tradução nossa), de modo que ele, ou não perceberia tais correntes ou as experienciaria de forma distorcida. Em ambas as situações, o indivíduo deixaria de 
estabelecer contato direto, sélfico, com os “processos vivos" (REICH, 1949/1973c, p. 60, tradução nossa) e perderia, consequentemente, a possibilidade de compreendê-los de forma profunda ou, na linguagem reichiana, de forma funcional (mais adiante, analisaremos em detalhes esses processos de abafamento e distorção das sensações plasmático-vegetativas). ${ }^{69}$

Ao se ver na presença de alguém que apresenta uma mobilidade plasmática “livre", o sujeito encouraçado, de acordo com o autor, tenderia a sentir a motilidade alheia como "algo estranho e perturbador", podendo até mesmo experienciar certa "ansiedade consciente". Em “todos os casos de encouraçamento" seria possível observar não apenas esse profundo temor da “motilidade livre” (REICH, 1949/1973c, p. 61, tradução nossa) de outros indivíduos, como também, a existência e consequente risco de irrupção de impulsos cruéis e sádicos.

Para Reich, o sadismo seria resultado da tentativa frustrada de o "ser humano encouraçado” dar expressão aos seus ímpetos plasmáticos primários como os "impulsos amorosos" -, posto que tais ímpetos inevitavelmente se chocariam com as fortes limitações impostas pela couraça (ou a paralisia da motilidade plasmático-vegetativa). O impulso primário continuaria, entretanto,

\footnotetext{
${ }^{69}$ Como mencionamos logo acima, a polarização estrutura encouraçada/estrutura desencouraçada é uma constante na obra reichiana. Embora concebesse a existência de brechas na couraça, que promoveriam acesso, mesmo que raramente, ao assim chamado núcleo sélfico, Reich, ao falar do caráter, estrutura ou organização desencouraçada, não parecia estar se referindo a um sujeito que vivencia estados ou contatos fugazes associados aos seus (empregando-se a terminologia do autor) impulsos primários, mas sim, a um indivíduo que, salvo condições excepcionais, teria contato direto, vívido e cotidiano com seus ímpetos profundos. Ainda que ultrapasse nossos objetivos, aqui, investigar possíveis reducionismos nesse posicionamento reichiano, parece-nos que uma análise crítica precisaria iniciar com a ideia que dá fundamento à polarização em pauta, ou seja, a noção de impulsos primários e impulsos secundários. Pois, para o autor, seria em torno dos impulsos primários que basicamente gravitaria a existência do indivíduo desencouraçado, ao passo que o sujeito encouraçado estaria realizando um esforço contínuo e exaustivo, seja para conter seus impulsos secundários, seja para acessar seus ímpetos primários. A nosso ver, essa dicotomia entre impulsos primários e secundários contém importante porta de entrada para um exame crítico da proposição reichiana de que a humanidade estaria basicamente dividida em indivíduos encouraçados e desencouraçados.
} 
exercendo pressão no e pelo sistema plasmático, como que buscando a todo custo uma solução periférica ou expressão emocional (a consecução, na superfície organísmica, do ímpeto profundo). Esse exaustivo processo promoveria, por fim, uma mudança na qualidade do impulso. Pois, ao forçar sua passagem, o impulso original se transformaria em "ódio e crueldade" (REICH, 1949/1973c, p. 124, tradução nossa): “O organismo tenta romper a couraça à força, como se estivesse aprisionado" (p. 120, tradução nossa).

Por outro lado, o indivíduo desencouraçado, que estaria bastante coadunado com seus impulsos primários e dotado de “capacidade para convulsão orgástica e descarga do excesso de bioenergia” (REICH, 1950/1990e, p. 1, tradução nossa), teria possibilidade, na visão reichiana, de perceber e compreender a importância crucial das emoções (os movimentos plasmático-espontâneos), tanto as de outras pessoas, como as suas próprias. Para Reich, esse ser humano não encouraçado conseguiria manter contato - valendo-se de sua sensorialidade plasmática - "com a natureza dentro e fora dele” (REICH, 1949/1973c, p. 116, tradução nossa).

Por experienciarem sensações e condições plasmáticas muito distintas, o sujeito encouraçado e o sujeito não encouraçado apresentariam concepções de mundo radicalmente opostas. Pois, na visão reichiana, "a qualidade das apreciações formuladas pelo indivíduo" e "as reações baseadas nessas apreciações" dependeriam, em derradeira instância, da "qualidade das sensações [plasmáticas]" (REICH, 1949/1973c, p. 56, tradução nossa). Para o autor, haveria uma ligação direta entre o grau de motilidade plasmático-vegetativa (numa escala que iria da pulsatilidade livre ao mais rígido encouraçamento) e a visão de mundo do sujeito (que iria, como veremos mais adiante, de engessadas concepções mecano- 
metafísicas, negadoras da vida, a flexíveis concepções funcionais, afirmadoras da vida). ${ }^{70}$

Por ter trabalhado terapeuticamente, durante um longo período, para que um "grande número de organismos encouraçados" pudesse experienciar "o fluxo de sua corrente orgonótica”, o autor sentia-se gabaritado para afirmar que a "atitude em relação à vida” ou a “"visão de mundo”” (REICH, 1949/1973c, p. 61, tradução nossa) estaria diretamente subordinada à capacidade de movimento do protoplasma do indivíduo. A experiência clínica teria demonstrado, ao autor, que a presença de fluídas correntes vegetativas e sua integração na experiência orgástica se traduziriam em uma concepção afirmativa em relação ao fenômeno da vida, ao passo que o crônico encouraçamento estaria frequentemente associado a uma visão de mundo negadora da vida, que pendularia entre a resignação depressiva e o sadismo cruel (voltaremos a esse tema, mais adiante).

\footnotetext{
${ }^{70}$ Contando com dados extraídos de suas diversas linhas investigativas (trabalho clínico, estudos antropológicos, pesquisa laboratorial orgonômica), Reich especulou sobre como a "função humana do conhecimento" teria surgido do substrato dos "eventos naturais" (REICH, 1951/1973b, p. 277-278, tradução nossa, grifo do autor). Em texto intitulado "The rooting of reason in nature", integrado ao seu livro Cosmic Superimposition, o autor ponderou, inicialmente, que o surgimento da vida em nosso planeta teria ocorrido por meio do confinamento do "fluxo cósmico" de energia orgone em uma membrana, confinamento esse que resultaria no surgimento, na criatura vivente, de outro fluxo ou corrente: as correntes plasmáticas. Passado longo período de tempo, a energia orgone organísmica teria desenvolvido a capacidade de "perceber seu próprio fluxo": "expansão no "prazer', contração na 'angústia'” (p. 291, tradução nossa, grifo do autor) (o autor não esclareceu, porém, como essa primitiva capacidade perceptiva teria surgido do protoplasma orgonoticamente excitado). Partindo desses pressupostos, o cientista cogitou que o "ser humano", em algum ponto remoto de sua trajetória evolutiva, teria começado a "raciocinar acerca de suas próprias sensações de correntes" e, também, acerca de sua capacidade "de perceber a si mesmo e de perceber, de uma forma geral" (p. 293, tradução nossa, grifo do autor). Admitindo que tais análises, ainda que apoiadas em indícios provenientes de diferentes ramos de pesquisas, esbarravam na imensa dificuldade de reconstituir eventos ocorridos em tempos tão remotos, Reich, entretanto, considerou lícito supor que a função de raciocínio teria tido início quando o animal humano, para utilizarmos uma expressão cara ao autor, tomou suas próprias sensações plasmáticas como objeto privilegiado de atenção. Mas, cabe indagar, e o inverso, a influência da esfera intelectual na dinâmica da vida? A esse respeito, parece-nos bastante feliz a seguinte reflexão do psicólogo bielorrusso Lev Vigotski (1896-1934), em obra publicada logo após seu precoce falecimento: "Por certo que a vida determina a consciência. Esta surge da vida e forma só um de seus momentos. Mas, uma vez nascido, o próprio pensamento determina a vida, ou, mais precisamente, a vida pensante se determina a si mesma por meio da consciência" (VYGOTSKI, 1935/1997, p. 269, tradução nossa).
} 
Continuamente ampliando, à medida que sua pesquisa avançava, o conceito de couraça, o autor propôs, especialmente em seus escritos orgonômicos, que haveria dois grandes grupos de encouraçamentos: a estrutura “mecanicista" e a estrutura "mística” (REICH, 1949/1973c, p. 10, tradução nossa). A humanidade, de acordo com a perspectiva reichiana, seria basicamente constituída por essas duas (e prevalentes) estruturas encouraçadas e por um terceiro (e bastante raro) tipo de organização, a estrutura “desencouraçada” (REICH, 1950/1990e, p. 1, tradução nossa). Se o grau de encouraçamento poderia ser aferido pelo impacto ou profundidade, na vida do indivíduo, de seu bloqueio emocional (a paralisia da pulsatilidade protoplasmática, de acordo com a conceituação reichiana), os grandes grupos de estruturações remeteriam, por sua vez, à atitude básica do sujeito diante de suas próprias correntes vegetativas. Adiantando-nos a nossos estudos, cabe comentar, por ora, que, na visão reichiana, as sensações plasmáticas mostrar-se-iam bloqueadas na estrutura mecanicista, distorcidas na estrutura mística e vivenciadas afirmativamente, na estrutura não encouraçada (REICH, 1949/1973c).

Interessado em avaliar, em suas reflexões epistemológicas, o papel do encouraçamento na produção científica, Reich insistiu que o ato de investigação e seus resultados não estariam imunes à “estrutura de caráter” (REICH, 1949/1973c, p. 108, tradução nossa) do pesquisador. Em diversas oportunidades, ele procurou demonstrar que o contato do cientista com suas próprias correntes vegetativas poderia desempenhar papel fundamental em sua atividade investigativa.

Mas, antes de analisarmos de forma mais detalhada os diferentes gêneros de estruturação - os dois tipos encouraçados e o tipo não encouraçado - e as modelações (de teor mecanicista, metafísico ou 'funcional') que eles imprimiriam, 
em linhas gerais, à pesquisa científica, cabe examinar outra noção empregada pelo autor, pois ela tem potencial para iluminar a concepção reichiana de estrutura moduladora da sensorialidade plasmática. Trata-se do conceito de organização.

Referimo-nos, anteriormente, à proposição reichiana de que a sensação seria o "único portal” a dar acesso "ao entorno e à nossa própria organização" (REICH, 1944/1991a, p. 28, tradução nossa). Em Ether, God and Devil, o autor, em uma passagem em que fez breves menções a Lange e Kant, ampliou suas considerações sobre a questão da “organização”, ponderando: a) que a “organização física” do sujeito determinaria suas "observações e apreciações"; b) que "a organização e funcionamento do organismo vivo" deveriam ser vistos como os mais importantes “critérios do conhecimento científico em geral”; c) que a "organização biológica" estaria na raiz de “todo conhecimento" (REICH, 1949/1973c, p. 62-63, tradução nossa).

Depreende-se, dessas citações, que Reich via na "organização" do sujeito o estofo em que se processariam os dados dos sentidos, as avaliações a respeito da realidade e a produção de conhecimento, inclusive, o saber científico. Trata-se, portanto, de um tema central, cujas raízes filosóficas merecem ser prospectadas. Como veremos mais adiante, o resgate histórico desse conceito de "organização" permitirá compreender melhor a asserção reichiana de que as estruturas de caráter, com seus modos próprios de se relacionarem com as sensações plasmáticas, imprimiriam, cada qual à sua maneira, singulares moldes epistêmicos ao conhecimento científico.

É em Lange (e no contraste que o pensador estabeleceu com tradicionais teses kantianas acerca da produção do conhecimento) que é preciso buscar, como insinuou o próprio Reich, as fontes da noção de “organização”. Tomaremos então 
esse atalho, procurando averiguar a noção langeana de organização e a forma pela qual Reich a retrabalhou a partir dos conceitos de couraça e sensação plasmática.

\subsubsection{Organização psicofísica}

Para iniciarmos essa breve análise, cabe lembrar que Lange integrou a assim chamada corrente neokantiana, constituída por pensadores interessados em encontrar a "fórmula adequada" (DILTHEY, 1949/1992, p. 223, tradução nossa) para unir Kant à ciência natural. Fundamentando-se em certas pesquisas de época a respeito da fisiologia dos órgãos dos sentidos, Lange insistiu que toda experiência e pensamento do indivíduo estariam submetidos a sua "organização psicofísica" (LANGE, 1865/1879, vol. 2, p. 43, tradução nossa). Tratar-se-ia, como esclareceu um comentador da obra do filósofo, de certa estrutura a priori, de evidente inspiração kantiana, que transformaria os "dados sensíveis em conhecimento" (ROSSET, 2006, p. 38). Os limites do conhecimento seriam aqueles impostos pela estrutura psicofisiológica do sujeito, de modo que "outra organização" psicofísica submetida aos "mesmos objetos" iria percebê-los de maneira "completamente distinta", comprovando-se assim a tese de que "a coisa em si" de Kant jamais estaria, de fato, ao alcance de "qualquer ser finito" (LANGE, 1865/1879, vol. 2, p. 6, tradução nossa).

Ao colocar ênfase na organização psicofísica, Lange, como veremos a seguir, diferenciou-se de seu mestre no que tange à caracterização das estruturas apriorísticas envolvidas na produção do conhecimento. Acompanharemos, ainda que panoramicamente, essas diferenças entre os dois filósofos, pois elas constituíram a via teórica que, a nosso ver, desembocou na compreensão reichiana 
de uma organização ou estrutura que determinaria o teor epistêmico (mais ou menos mecanicista, mais ou menos espiritualista, mais ou menos 'funcional') das primitivas sensações plasmáticas.

Comecemos, então, por alguns aspectos do pensamento de Kant. Em sua célebre tentativa de examinar os alcances e limites do conhecimento, fazendo a razão voltar-se a si mesma (PASCAL, 2008), o filósofo de Königsberg ponderou, em sua Kritik der reinen Vernunft, ${ }^{71}$ que a mais simples "forma lógica de nosso conhecimento" poderia conter "conceitos puros a priori", conceitos esses que, "previamente a qualquer experiência, representam os objetos" (KANT, 2001, p. 267, tradução nossa). Lange explicou da seguinte maneira essa formulação:

\begin{abstract}
Kant demonstrou, inicialmente por meio da matemática, que nosso pensamento realmente dispõe de certo conhecimento a priori e que nem mesmo a formulação mais corriqueira ocorreria sem esse tipo de conhecimento. A partir disso ele procurou mostrar que, não apenas na matemática, mas em cada ato do conhecimento, elementos apriorísticos cooperam e amplamente condicionam nossa experiência (LANGE, 1865/1879, vol. 2, p. 34, tradução nossa).
\end{abstract}

A existência de elementos apriorísticos não significava, entretanto, que Kant duvidasse que o conhecimento começava com a "experiência" - "de que maneira nossa capacidade de conhecer", indagou o pensador, "poderia ser despertada e colocada em ação se não fosse pelos objetos que excitam nossos sentidos?". Na perspectiva kantiana, esses objetos estimulariam ou produziriam “representações” que o intelecto ver-se-ia impelido a comparar, reunir ou distinguir, trabalhando, dessa forma, a “matéria bruta das impressões dos sentidos para extrair delas um conhecimento dos objetos". Por isso Kant julgava que, "cronologicamente",

\footnotetext{
${ }^{71}$ Valemo-nos aqui de uma tradução francesa da obra do filósofo alemão: Critique da la raison pure (Kant, 2001)
} 
nenhum conhecimento precederia a experiência sensorial, e que todo conhecimento começaria por ela. Mas o fato de o conhecimento ter como ponto de partida a experiência não significa que ele derivaria "inteiramente dela". Seria mais plausível supor, argumentou o célebre filósofo, que nosso “conhecimento experiencial" representasse uma composição daquilo que "recebemos das impressões dos sentidos" e daquilo que "nossa própria capacidade de conhecer (simplesmente excitada por impressões dos sentidos) produz por si mesma [...]" (KANT, 2001, p. 31, tradução nossa, grifo do autor). Tentemos nos aprofundar um pouco mais nessas proposições kantianas.

Howard Caygill, em seu Dicionário Kant, comentou que o filósofo alemão considerava como uma das principais realizações de sua crítica da razão pura a distinção entre “ideias transcendentais ou 'conceitos puros da razão’ e as categorias ou "conceitos puros do entendimento'” (CAYGILL, 2000, p. 178). Estas últimas, as categorias, seriam independentes dos objetos, mas concordantes com eles; elas se coligariam necessariamente e a priori aos objetos da experiência, permitindo que os objetos pudessem ser pensados (KANT, 2001). As ideias transcendentais ou conceitos puros da razão, no entanto, estariam situadas para além da apreensão dos sentidos, como explicou o filósofo:

As ideias [transcendentais] estão ainda mais distantes da realidade objetiva do que as categorias; pois não se pode encontrar qualquer fenômeno no qual elas possam ser representadas in concreto. Elas contêm certa perfeição que não está ao alcance de nenhum conhecimento empírico possível [...] (KANT, 2001, p. 413, tradução nossa).

O idealismo kantiano propunha, em outras palavras, que o "espírito intervém ativamente na elaboração do conhecimento e que o real, para nós, é resultado de 
uma construção" (PASCAL, 2008, p. 36). Nesse idealismo transcendental a razão conteria, em suma, certos elementos apriorísticos que permitiriam ordenar o "real", de forma que todo objeto de conhecimento seria determinado a priori “pela própria natureza de nossa faculdade de conhecer” (p. 45).

Voltemos, agora, a Lange e ao seu conceito de "organização psicofísica”, seguindo a tentativa do filósofo de encontrar algum acordo entre o idealismo kantiano e a moderna pesquisa em ciências.

Embora considerasse que o materialismo fosse estéril como visão de mundo e limitadíssimo para abarcar a subjetividade humana, Lange reconheceu na concepção mecano-materialista um indispensável método de pesquisa (já havíamos notado esse posicionamento quando resgatamos suas contribuições para o nascimento da psicologia científica). Em sua Geschichte des Materialismus o pensador aclamou, inclusive, a valiosa contribuição da pesquisa empíricomaterialista para a elucidação dos mistérios do Universo. Mas ele ponderou, igualmente, que o idealismo kantiano jamais deveria ser descartado na busca da "verdade", posto que, a seu ver, as ideias transcendentais seriam "tão indispensáveis quanto os fatos para o progresso das ciências” (LANGE, 1865/1950, vol. $2,2^{\cdot a}$ seção, p. 341, tradução nossa).

Distante das informações sensoriais, tão caras aos materialistas, o "ponto de vista do Ideal" revelar-se-ia indubitavelmente, de acordo com Lange, nos domínios da Arte, Filosofia e Religião. Mas as “ideias" ou "conceitos puros da razão" não deixariam de fazer parte e determinar, também, a pesquisa científica; assim, o Idealista, na visão langeana, também poderia ser “um cientista investigador”. A “moderna investigação científica” teria, inclusive, tornado difícil delimitar com clareza as influências do Materialismo e do Idealismo. E o cientista que conseguisse 
combinar a investigação experimental com a visão idealista, sem introduzir “confusão, obscuridade ou estéril timidez em suas pesquisas”, alcançaria "um alto padrão de genuína e completa humanidade" (LANGE, 1865/1950, vol. 2, 4.a seção, p. $358-359) .^{72}$

Procurando equacionar a pesquisa científica prática e o idealismo kantiano, Lange ponderou:

As ideias científicas originam-se, assim como as ideias poéticas e metafísicas, da interação de todos os elementos da mente humana. Mas tomam um curso diferente, pois estão submetidas elas mesmas ao julgamento da investigação, no qual apenas os sentidos, o entendimento e a consciência científica são os juízes (LANGE, 1865/1950, vol. 2, 2.a seção, p. 341, tradução nossa).

Esse "idealismo material" langeano resultou em algumas diferenças em relação ao pensamento de Kant. Lange adotou, certamente, o ponto de vista kantiano de que o conhecimento humano não resultaria de um espelhamento direto dos objetos externos, mas sim, de uma organização/modelação apriorística dos dados sensoriais: "em todo conhecimento encontra-se um elemento que provém não da influência externa, mas da essência do sujeito do conhecimento" (LANGE, 1865/1879, vol. 2, p. 37, tradução nossa). Mas, pautando-se por pesquisas fisiológicas de época a respeito do "aparato cognitivo humano" (MOORE, 2002, tradução nossa), ${ }^{73}$ Lange não situou as estruturas apriorísticas (responsáveis por

\footnotetext{
${ }^{72}$ Curioso observar que agradou ao jovem Reich, quando ele leu a Geschichte des Materialismus, a defesa langeana da "indispensabilidade da filosofia idealista da vida" (REICH, 1942/1989, p. 24, tradução nossa).

${ }^{73}$ Lange sofreu forte influência do médico e cientista Hermann von Helmholtz (1821-1894), um dos nomes mais importantes da ciência alemã da segunda metade do século XIX. Helmholtz circulou, ao longo de sua obra, por diversas áreas do conhecimento, sendo frequentemente lembrado por suas pesquisas nos campos da eletrodinâmica, hidrodinâmica, astrofísica e termodinâmica (ele contribuiu significativamente para a formulação da lei da conservação de energia) e fisiologia (estudioso dos órgãos dos sentidos, o cientista se dedicou especialmente à ótica e à acústica).
} 
transformar as informações dos sentidos em conhecimento organizado) nas formas da intuição (as formas a priori do espírito em que nada haveria referente à sensação) ou nas categorias kantianas (TEO, 2002), mas, como apontamos anteriormente, na “organização psicofisiológica” (LANGE, 1865/1879, vol. 2, p. 43, tradução nossa). Para Lange, os elementos apriorísticos responsáveis pela sistematização do conhecimento não deveriam ser procurados nos confins da razão, mas na estrutura, organização ou limites do próprio corpo.

Essa “organização”, como esclareceu um comentador, diria respeito a "um conjunto de funções físicas (anatomofisiológicas) e psicológicas (intelectuais)” que regulariam “como e o que podemos pensar e sentir”. Tanto o âmbito intelectual (entendimento), quanto o âmbito da percepção (sensibilidade) estariam condicionados ao "aparato anatomofisiológico", aparato esse que, em derradeira instância, seria responsável por nossa capacidade de “representar e conhecer objetos" (GARCIA, 2008, p. 53).

Em Ether, God and Devil, Reich citou um trecho da Geschichte des Materialismus, em que Lange professava a esperança de que a filosofia kantiana viesse a se conciliar, em algum momento, com a fisiologia: “Talvez a base da ideia de causalidade possa ser encontrada, um dia, no mecanismo do movimento reflexo e da excitação simpática; nós então traduziremos a razão pura de Kant para a fisiologia, tornando-a assim mais acessível” (LANGE citado em REICH, 1949/1973c, p. 63, tradução nossa; LANGE, 1865/1950, vol. 2, 1.a seção, p. 211). Reich acreditava que sua teorização madura havia cumprido, finalmente, aquela “importante predição” langeana. De certa forma, Reich se dedicou ao “mecanismo do movimento reflexo" (especialmente, o reflexo orgástico) e a investigação da “excitação simpática” (a motilidade vegetativa, na linguagem reichiana). Mas ele 
acreditava ter identificado, sobretudo, o "sentido básico de natureza estritamente fisiológica” (REICH, 1949/1973c, p. 63, tradução nossa, grifo do autor) que coligaria a esfera biológica (protoplasmática) à produção de conhecimento, a saber, as sensações vegetativas, de órgão ou orgonóticas. Na visão do autor, tal sensorialidade plasmática seria, como mencionamos em outros momentos, de natureza essencialmente biológica ou bioenergética e expressaria estados de movimento do protoplasma orgonoticamente excitado.

Para o autor, o intelecto funcionaria como "órgão executor do plasma vivo" e sondaria a "natureza" - "fora e dentro de nós" - por meio das "sensações de órgão” (REICH, 1949/1973c, p. 96, tradução nossa). Reich acreditava que as investigações concernentes à dinâmica da sensação plasmático-vegetativa poderiam conduzir até mesmo à das Ding an sich, a coisa em si kantiana:

Se conseguíssemos compreender a função da percepção e da sensação per se em termos energéticos (orgonoticamente), isto é, estudando sua verdadeira natureza, desenvolveríamos um acesso a das Ding an sich. $\mathrm{Na}$ produção de Freud o 'inconsciente' desempenhou o papel de das Ding an sich na organização psíquica e tornou-se, assim, instrumento da pesquisa natural. A descoberta da energia orgone deu-se por meio do estudo amplo e consistente das funções de energia, primeiro no campo da psique e, depois, no campo do funcionamento biológico. 0 pilar dessa pesquisa foi a sensação de órgão (REICH, 1949/1973c, p. 62, tradução nossa, grifo do autor).

Do ponto de vista reichiano, a sensação de órgão ou plasmático-vegetativa (fenômeno que teria tido importante participação, como se observa na citação acima, na própria produção reichiana $)^{74}$ seria, em suma, uma crucial função

\footnotetext{
${ }^{74} \mathrm{Em}$ um texto de caráter metodológico, editado em 1950, Reich admitiu que suas hipóteses de começo de carreira tiveram como substrato certas sensações vivenciadas por ele mesmo. Ponderando sobre as razões que o levaram a especular, por volta de 1919-20, a respeito da possível existência de uma energia primária, ele comentou que suas incipientes suposições talvez tivessem a ver com determinadas
} 
biológica que daria sustentação à produção do conhecimento. Por outro lado, Reich insistiu que a sensação de órgão seria sempre filtrada pela estrutura do sujeito, estrutura essa que poderia imprimir, à sensorialidade plasmática, tons mecanicistas, espiritualistas, ou 'funcionais'. Para Reich, haveria, assim, como que um caminho de duas mãos: a motilidade plasmática e sua correspondente sensorialidade seriam o fundamento biopsíquico para a produção do conhecimento, mas essa sensorialidade seria, ao mesmo tempo, modelada pela estrutura ou organização do indivíduo.

Se, para Kant, o conhecimento, embora não prescindisse da sensação, receberia forte contribuição dos elementos apriorísticos próprios à faculdade de conhecer, e se, para Lange, as sensações estariam sempre subordinadas aos limites da organização psicofisiológica do sujeito, para Reich haveria uma estrutura modeladora, fortemente enraizada e de amplo alcance que colorizaria as sensações plasmáticas. A essa estrutura valorativa, que determinaria o posicionamento epistêmico do sujeito em relação à sua própria sensorialidade vegetativa, o autor denominou de “estrutura de caráter” (REICH, 1944/1991a, p. 37, tradução nossa) ou “estrutura biopsíquica” (REICH, 1946a, p. vii, tradução nossa).

Vejamos, então, algo sobre esse conceito reichiano de estrutura, para caminharmos, em seguida, aos seus tipos gerais (mecanicista, espiritualista, desencouraçado), examinando como cada um deles processaria as sensações plasmáticas e, de acordo com as pesquisas do autor, a própria produção de conhecimento científico.

“sensações de movimento" (REICH, 1950/1990d, p. 4, tradução nossa) provenientes de seu próprio corpo. A produção reichiana adotou, aliás, como seu primeiro objeto de estudo as “(tão denegridas) sensações de prazer" (REICH, 1949/1973c, p. 44, tradução nossa). 


\subsubsection{Estrutura biopsíquica}

Pode-se observar, em diferentes momentos da produção reichiana, a ideia de que haveria uma instância que pautaria ou mesmo determinaria os matizes da experiência subjetiva do indivíduo adulto e, consequentemente, sua visão de mundo. As primeiras formulações do autor, a esse respeito, remontam ao estágio inicial de sua produção, quando trabalhou como psicanalista em Viena e, depois, em Berlim.

Alguns anos após ter sido formalmente aceito na Associação Psicanalítica, Reich, sob forte influência da teoria psicossexual freudiana, publicou em 1925 o estudo Der Triebhafte Charakter - Eine psychoanalytische Studie zur Pathologie des Ich ("O caráter impulsivo - Um estudo psicanalítico sobre a patologia do Eu”). ${ }^{75}$ Para redigir o livro (o primeiro de sua carreira), o autor se beneficiou amplamente dos atendimentos que realizara por três anos com pacientes que apresentavam acentuados comportamentos antissociais (então denominados de "caráteres impulsivos"), mas que não se enquadravam facilmente nas categorias psicopatológicas bem estabelecidas:

Nesses 'caráteres impulsivos', [Reich] identificou atitudes intensamente 'regressivas', indicativas de certas fases primitivas do desenvolvimento mental, fases essas que não eram facilmente observáveis, in loco, em neuróticos típicos. Procedendo a uma análise comparativa entre as 'típicas neuroses com inibição dos impulsos' (histeria e neurose obsessiva) e os 'caráteres impulsivos', o autor trabalhou no sentido de ampliar a compreensão da gênese, desenvolvimento e funcionamento do ego, pois acreditava que 'a dinâmica do ego é mais difícil de ser compreendida do que a dinâmica do desenvolvimento sexual' (REICH, 1925/1975b, p. 237). Em sua 75 Valemo-nos aqui de uma tradução norte-americana da obra: “The impulsive character - A
psychoanalytic study of ego pathology" (REICH, 1925/1975b). 
opinião, a Psicanálise precisava aprimorar seu conhecimento a respeito das etapas de evolução do ego, como fizera inicialmente em relação aos estágios do desenvolvimento sexual (BEDANI, 2007a, p. 76-77).

A ideia de que elementos estruturais e arraigados da personalidade desempenhariam importante papel no posicionamento geral do sujeito em relação à realidade externa, já se fazia presente em Der Triebhafte Charakter. Nesse escrito, o caráter é definido como a "atitude psíquica particular - própria de um dado indivíduo - em relação ao mundo exterior”, atitude essa que seria determinada pelas experiências de vida e "temperamento" (REICH, 1925/1975b, p. 250, tradução nossa). Dando prosseguimento às suas investigações sobre o papel da dimensão caracterial nas patologias neuróticas, o autor realçou, em conferência proferida em 1927, que o caráter representaria “o modo específico de existência da pessoa", modo esse que conteria, estruturalmente, "todo o passado do indivíduo" (REICH, 1933/1973a, p. 48, tradução nossa).

Ao formular, no período 1925-1933, o método terapêutico da Análise do Caráter (REICH, 1933/1969), o autor deu especial atenção ao aspecto exterior dos traços caracteriais de seus pacientes, tendo inclusive aprimorado sua capacidade de "reconhecer e observar funções puramente formais" (REICH, 1994a, p. 1, tradução nossa). Interessavam a Reich, no trabalho clínico, os traços visivelmente automatizados e rígidos que limitariam sobremaneira o exercício crítico-intelectual e a vida emocional do paciente e cumpririam, em especial e última instância, a função de defesa à experiência da potência orgástica (o que qualificaria um traço como patológico seria justamente, na visão reichiana, o fato de ele funcionar como bloqueio direto à convulsão orgástica). Pautando-se pelo pressuposto de que a "forma" (substancializada, no caso da neurose, em comportamentos extremamente 
rígidos e inflexíveis) seria “o processo congelado da experiência”, o autor acreditava que, com sua metodologia terapêutica, haveria a possibilidade de, partindo do "aspecto formal das atitudes" (os traços enrijecidos superficiais), alcançar e mobilizar clinicamente os "processos de excitação" que teriam se tornado "congelados" (REICH, 1994b, p. 89, tradução nossa), especialmente o processo orgástico-genital. ${ }^{76}$

Reich, contudo, não se limitou a abordar os mecanismos internos da estrutura de caráter. A partir de 1927 ele procurou compreender, também, de um ângulo freudo-marxista, a dimensão sociológica da formação caracterial ou o caráter como “instância psíquica depositária da ideologia dominante” (BEDANI; ALBERTINI, 2006). Funcionando como um repositório que a todo o momento atualizaria as configurações defensivas historicamente construídas, o caráter neurótico, na visão reichiana, continuamente imprimiria às experiências pessoais tons moralístico-patriarcais, o que dificultaria sobremaneira o exercício reflexivo e crítico do indivíduo.

Considerando que “cada organização social produz as estruturas de caráter que precisa para sobreviver”, o autor esclareceu, em 1933, que, para a ideologia dominante, não se trataria apenas de inculcar uma doutrina "por meio de atitudes e opiniões". A ideologia prevalente procuraria ir mais longe, tentando implementar um "processo de longo alcance" que atingisse "cada nova geração de uma dada sociedade", com o objetivo de "modificar e modelar as estruturas psíquicas (em todas as camadas da população) de acordo com a ordem social" (REICH, 1933/1973a, p. xxii-xxiii, tradução nossa).

\footnotetext{
${ }^{76}$ Uma ampla análise dos estudos psicanalíticos de Reich sobre o caráter pode ser encontrada em Oliveira e Silva (2001).
} 
Em sua autobiografia científica de 1942, o cientista, já distante da Associação Psicanalítica e do movimento político-partidário de esquerda, sintetizou da seguinte forma suas reflexões sobre a "relação direta entre a estrutura social e a estrutura do caráter":

\begin{abstract}
A sociedade molda o caráter humano. Por sua vez, o caráter humano reproduz, em massa, a ideologia social. É assim que, reproduzindo a negação da vida inerente à ideologia social, as pessoas geram sua própria supressão. Esse é o mecanismo básico da assim chamada tradição (REICH, 1942/1989, p. 187, tradução nossa, grifo nosso).
\end{abstract}

Para designar, na fase orgonômica de sua produção, a "ativa reprodução da história” (REICH, 1999, p, 325, tradução nossa) em âmbito individual, o autor, além de empregar expressões como “estrutura de caráter humana” (REICH, 1949/1973c, p. 6, tradução nossa) e “estrutura humana média” (REICH, 1999, p. 422, tradução nossa), fez uso, também, de outras denominações, tais como "estrutura biofísica” (REICH, 1949/1973c, p. 48, tradução nossa) e “estrutura biopsíquica” (REICH, 1946a, p. vii, tradução nossa).

Partindo do pressuposto de que "cada percepção e sensação" seria tingida pela “estrutura de caráter” (REICH, 1944/1991a, p. 37, tradução nossa), o autor, como comentamos anteriormente, fez diversas referências, nas décadas de 1940 e 1950, a três tipos gerais de organizações ou estruturas biopsíquicas que colorizariam, cada qual a sua maneira, a sensorialidade plasmática: a estrutura mecanicista, a estrutura mística e a estrutura desencouraçada (REICH, 1949/1973c). Cada uma dessas organizações imprimiria uma específica orientação epistêmica às sensações de órgão, e essas orientações se traduziriam, por sua vez, em distintos estilos de raciocínio. 
Examinaremos agora, com mais detalhes, tais organizações, começando com a estrutura mecanicista e a estrutura mística.

\subsection{Estrutura mecanicista e estrutura mística}

Reich afirmou ter se deparado, desde o início de sua carreira, com dois poderosos “sistemas de pensamento", o “mecanicismo" e o “misticismo”, os quais possuiriam fortes raízes históricas e seriam sustentados por "poderosas organizações sociais”. 0 “mecanicismo” englobaria "o materialismo, o atomismo, o quimismo etc.", ao passo que o "misticismo" abarcaria "o idealismo, a metafísica, o espiritualismo etc." (REICH, 1950b, p. 3, tradução nossa). Ambas as vertentes, no entendimento reichiano, seriam inapropriadas para a compreensão da especificidade do fenômeno vivo (REICH, 1942/1989) e da sensorialidade plasmática, de modo que o autor, preocupado com a eficácia de sua atuação como médico e cientista, pôs-se a buscar concepções metodológicas que superassem as limitações que, a seu ver, seriam inerentes àquelas duas visões de mundo (REICH, 1949/1973c).

Para Reich, a expansão das fronteiras científicas ficara a cargo, especialmente, de pesquisadores não ortodoxos que se insurgiram contra o “mecanicismo" e o “misticismo”. Como "rebeldes da ciência natural” e "rebeldes no pensamento", esses pesquisadores teriam caminhado, com ousadia e vivacidade, "através das barreiras", enfrentando dogmas que recaíam sobre "a imutabilidade das substâncias químicas, as relações entre energia e massa, as relações entre humano e animal etc." (REICH, 1949/1973c, p. 108-109, tradução nossa). 
As visões de mundo "mecanicista" e "mística" teriam, no entanto, se tornado prevalentes e poucos cientistas conseguiriam escapar delas:

O mecanicista e o místico estão, ambos, envoltos nas limitações e determinações conceituais de uma civilização dominada por um compósito contraditório e mortífero de máquinas e deuses. Esta civilização forma as estruturas mecanicistas-místicas dos homens, e são as estruturas de caráter mecanicistas-místicas que reproduzem a civilização mecanicista-mística (REICH, 1949/1973c, p. 10, tradução nossa).

Um aspecto unificaria, no entanto, as "filosofias de vida mecanicista e mística": cada uma delas atacaria, a sua maneira, "o elemento vivo no animal humano", derivando suas formas de pensar da "negação da vida" (REICH, 1949/1973c, p. 13, tradução nossa, grifo do autor); ademais, elas manifestariam, em algum momento e com consequências sociais mais ou menos drásticas, um intenso “ódio à Vida” (REICH, 1953/1975c, p. 5, tradução nossa). Em suma, a negação e o ódio à vida seriam indissociáveis daquelas duas organizações biopsíquicas - a estrutura mística e a estrutura mecanicista -, organizações essas que ainda teriam em comum 0 fato de apresentarem um profundo encouraçamento.

Do ponto de vista reichiano, a estrutura biopsíquica determinaria, como comentamos anteriormente, o valor ou grau de importância que o sujeito atribuiria às suas próprias sensações plasmáticas. Essa valoração expressaria o posicionamento do indivíduo diante do fenômeno da vida: negação e, até mesmo, ódio à motilidade viva espontânea, no caso das estruturas encouraçadas místicas e mecanicistas, e afirmação e acolhimento, no caso das estruturas não encouraçadas. Vejamos, de forma mais detalhada, os estudos de Reich, em seu período 
orgonômico, a respeito da estrutura encouraçada de orientação mecanicista (mais adiante examinaremos as ponderações reichianas acerca da estrutura mística). Tais estudos, como veremos a seguir, tiveram como núcleo a questão da sensação de órgão e focaram o distanciamento do indivíduo em relação à sua sensorialidade plasmática.

\subsubsection{Encouraçamento e mecanicismo}

Para Reich, o rígido posicionamento mecano-materialista e o processo de encouraçamento seriam fenômenos correlatos e, para exemplificar sua tese, ele fez referências, em Ether, God and Devil, à forma de pensar do "físico mecanicista típico". Esse físico seria, na visão reichiana, completamente escravo do raciocínio mecanicista e pensaria de acordo com os "princípios de construção das máquinas". De forma semelhante à máquina, que precisa ser a mais perfeita possível, o físico mecano-materialista precisaria, ele também, ser “"perfeito””. O perfeccionismo seria, inclusive, "uma característica essencial do pensamento mecanicista" (REICH, 1949/1973c, p. 82, tradução nossa, grifo do autor), pensamento esse que, na avaliação do autor, não toleraria erros, incertezas e condições em fluxo.

Mas a natureza, diferentemente do que pudesse vir a acreditar o pesquisador encastelado no rígido mecanicismo, operaria, insistiu Reich, essencialmente de maneira 'funcional', ou seja, de forma não mecânica, 'espontânea', automovente e capaz de autorregulação:

Todas as máquinas do mesmo tipo são idênticas até nos mínimos detalhes. Desvios são vistos como falta de precisão. No que concerne à construção de máquinas isso é perfeitamente correto. Mas tal 
princípio conduzirá ao erro se for aplicado aos processos da natureza. A natureza é imprecisa. Ela não opera mecanicamente, mas sim, funcionalmente (REICH, 1949/1973c, p. 83, tradução nossa).

O autor chamou atenção para o fato de que a natureza, ainda que regida por leis, apresentaria, a todo tempo, variabilidade e imprecisão, desconhecendo, assim, "qualquer tipo de perfeccionismo". Exemplo disso seria uma floresta, local em que se poderia identificar um "princípio uniforme de crescimento", mas nunca duas árvores - nem duas folhas entre milhares de árvores - que se assemelhassem com precisão fotográfica, pois “o campo das variações” mostrar-se-ia, sempre, "infinitamente maior do que o campo da uniformidade". Em suma, "perfeccionismo e incerteza" (REICH, 1949/1973c, p. 83-84, tradução nossa) se excluiriam mutuamente.

No entendimento reichiano, a pesquisa acerca dos processos naturais teria como característica o fato de ser “tateante, 'irregular', instável, flexível, sempre passível de correção, em fluxo, incerta, insegura e, apesar disso, conectada aos processos reais". Esses "processos reais" estariam certamente sujeitos a leis gerais, mas apresentariam alto grau de variabilidade, sendo "livres no sentido de irregulares, imprevisíveis e não repetíveis" (REICH, 1949/1973c, p. 84, tradução nossa). A natureza, na concepção reichiana, não conheceria qualquer "burocracia": "Leis naturais são funcionais, não mecanicistas. Mesmo onde as leis do mecanicismo são válidas, a natureza é rica em variações" (p. 106, tradução nossa).

Além de apontar as rígidas limitações intelectuais que, a seu ver, seriam inerentes à estrutura mecanicista, Reich também procurou compreender os elementos internos que comporiam tal estrutura. Entre esses elementos, um seria central: o pânico das sensações orgástico-plasmáticas. 


\subsubsection{Angústia orgástica}

Em diversas oportunidades, o autor afirmou que o núcleo do encouraçamento humano residiria em um profundo temor em relação aos movimentos corporais "involuntários", movimentos esses que, como vimos anteriormente, se manifestariam indubitavelmente, do ponto de vista reichiano, na “convulsão orgástica” (REICH, 1942/1989, p. 108, tradução nossa). Ancorando-se em sua extensa prática clínica, que tinha como referencial de cura o restabelecimento das convulsões orgásticas, o autor deu àquele intenso receio a denominação de "angústia orgástica": "O prazer de viver e o prazer do orgasmo são idênticos. Uma extrema angústia orgástica forma a base do medo generalizado em relação à vida" (p. 162, tradução nossa).

Reich descobrira que a angústia orgástica se apresentava, no contexto clínico, como uma espécie de pânico ou mesmo de horror: "o horror às forças da vida no animal humano" (REICH, 1949/1973h, p. 503, tradução nossa, grifos do autor). Ele notou, também, que tal temor representava, por assim dizer, o último reduto do processo de encouraçamento, de modo que o paciente, ao tomar consciência dessa angústia defensiva e então a sobrepujar terapeuticamente, costumava ter acesso direto àquilo que ela defendia: a motilidade plasmática em sua expressão orgástica, ou, nas palavras do autor, a "convulsão bioenergética involuntária do organismo" (REICH, 1942/1989, p. 108, tradução nossa). Esse contato com a angústia orgástica em sua forma mais cristalina (praticamente sem os ruídos provenientes de outras camadas de encouraçamento) ocorreria no estágio final do tratamento, momento em que ela poderia se converter, a partir do suporte terapêutico, em prazer orgástico-plasmático, pois a mesma força contida na 
contração angustiante passaria a ser direcionada para fora, agora como expressão emocional expansiva (a consecução periférica da excitação protoplasmática).

O autor também chamou atenção para os perigos que resultariam de o indivíduo entrar em contato com a motilidade orgástico-plasmática sem dispor de um efetivo suporte terapêutico. Nesse caso, as sensações orgásticas de corrente suscitariam, de acordo com os relatos reichianos, não apenas um insuportável sentimento de angústia (o pânico do movimento espontâneo ou automovimento), mas também, uma custosa irrupção de impulsos secundários, posto que a excitação orgástica, buscando sobrepujar o crônico e cristalizado encouraçamento vegetativo, tentaria forçar passagem, o que resultaria, entre outras possibilidades, no surgimento de impulsos sádicos antissociais ou comportamentos autodestrutivos.

A couraça, em suma, expressar-se-ia por um amortecimento do movimento plasmático espontâneo e um simultâneo bloqueio à percepção direta desse movimento. Em diversas oportunidades, o autor insistiu que o encouraçamento teria por alvo, em última instância, a motilidade espontânea, motilidade essa que se manifestaria, de acordo com as pesquisas orgonômicas reichianas, tanto em estratos profundos da estrutura biopsíquica do sujeito, quanto em certos níveis de funcionamento da própria atmosfera. Pois, como comentamos anteriormente, tal movimento espontâneo tomaria raízes, segundo Reich, no automovimento de uma específica “força” - a energia orgone cósmica - que se faria presente nos campos do vivo e do não vivo.

O encouraçamento não deixaria de afetar, como sublinhou Reich, os profissionais da ciência, sendo o pesquisador de "estrutura mecanicista" um claro exemplo disso. No entendimento reichiano, gerações e gerações de cientistas teriam sofrido o encouraçamento de sua "vivacidade movente (motile aliveness)", 
de modo que "o princípio da vida em si mesmo, o movimento (o aspecto, de fato, mais importante da vida)" teria permanecido "um livro fechado" (REICH, 1949/1973c, p. 115, tradução nossa, grifo nosso). O rígido pesquisador mecanomaterialista estaria certamente apto, de acordo com a leitura reichiana, a captar o movimento mecânico, mas não a apreender a motilidade 'funcional', 'espontânea' dos fenômenos.

$\mathrm{Na}$ tentativa de abafar sua angústia orgástico-plasmática, o pesquisador mecanicista desenvolveria potentes defesas, encastelando-se obstinadamente em teorias e métodos rígidos que lhe dariam a ilusão de proteção real, mas que, em última instância, apenas aumentariam sua distância para com as sensações vegetativas:

A rigidez mecanicista, quando da observação e formulação de teorias, está muito mais a serviço da segurança pessoal do que da investigação objetiva. Pude notar várias vezes em mim mesmo e em muitos colaboradores, que este apego às leis e barreiras rígidas tem a função de nos livrar da inquietação mental. Por estranho que pareça, sentimo-nos menos ameaçados quando permitimos que o aspecto móvel se enrijeça do que quando investigamos um objeto em movimento (REICH, 1949/1973c, p. 107, tradução nossa).

O sujeito de estrutura mecanicista, no entendimento reichiano, nada perceberia, em suma, de seus fluxos plasmáticos. Resguardando-se de forma tenaz (devido a sua angústia orgástica) da irrupção dos movimentos vegetativos espontâneos, o “mecanicista” escudar-se-ia em uma fria objetividade, restando-lhe tão somente ansiar pelo paraíso perdido da vivacidade, dos brilhos, das "emoções” prazerosas. 0 profundo temor em relação à pulsatilidade vegetativa se expressaria intelectualmente como uma aridez lógica, reduto último de um indivíduo que teria 
perdido contato com suas vibrantes sensações de órgão, o mais importante sinalizador, segundo a leitura reichiana, do movimento espontâneo ou da propriedade (que se faria presente em estratos do vivo e do não vivo) do automovimento. Por isso, o indivíduo de estrutura mecanicista, caso viesse a ter algum acesso à sua sensorialidade plasmática ou à de outros indivíduos, a desprezaria radicalmente ou diminuiria sobremaneira seu valor.

As estruturas de caráter mecanicistas não teriam sido, contudo, as únicas a sofrerem disfunções no campo da sensorialidade plasmática; o problema afetaria severamente, também, as estruturas místicas. No entendimento do autor, “misticismo e superstição” seriam tendências que governariam "a mentalidade da maior parte da espécie humana, arruinando suas vidas” (REICH, 1949/1973h, p. 437, tradução nossa).

\subsubsection{Encouraçamento e misticismo}

Diferentemente da estrutura mecanicista, a estrutura mística teria algum acesso perceptivo, segundo Reich, ao movimento plasmático. Mas, por estar impossibilitado (pelo encouraçamento) de perceber a motilidade vegetativa como um fenômeno intrínseco à própria corporalidade, o "místico" conferiria às correntes protoplasmáticas uma origem sobrenatural. Capaz de sentir os fluxos vegetativos, mas interpretando-os como advindos de forças exteriores, o “homem místico" vivenciaria suas “emoções” (o movimento protoplasmático espontâneo) como se elas estivessem refletidas em um "espelho distorcido" (REICH, 1949/1973c, p. 92, tradução nossa). 
Portador de um tipo de encouraçamento que não lhe permitiria reconhecer suas “sensações de órgão” como percepções de uma excitação corporal objetiva e real, o "místico" transferiria projetivamente a "motilidade da vida" para quiméricas esferas suprafísicas, “para o além” (REICH, 1949/1973c, p. 115, tradução nossa). Se a estrutura mecanicista padeceria de um bloqueio de afeto que impediria qualquer aproximação com as sensações de órgão, a estrutura mística, por sua vez, julgaria de forma distorcida seus próprios fluxos vegetativos, de modo que "qualquer tentativa de conduzir um místico ao contato direto com sua excitação" poderia disparar rapidamente "sua angústia ou mesmo a inconsciência". O "místico", de acordo com os estudos reichianos, apenas poderia perceber a emoção “como em um espelho, nunca como realidade” (p. 92-93, tradução nossa). Daí o sentido que o cientista atribuía ao termo “"misticismo””: “uma transformação, literalmente, das impressões sensoriais e sensações de órgão em algo irreal e para além deste mundo” (p. 92-88, tradução nossa).

De acordo com as pesquisas do autor, o sujeito de estrutura mística poderia recorrer até mesmo à brutalidade para conquistar a “imagem espelhada". Isso ocorreria caso a "vida no espelho" se tornasse uma "provocação constante" para o próprio indivíduo, havendo inclusive o risco, nesse caso, de irrupção de delírios:

Lá está a motilidade; ela vive, ri, chora, odeia, ama, mas sempre e somente no espelho. Na verdade, o Eu se vê tão impossibilitado de acessar a motilidade, quanto estava Tântalo de alcançar as frutas (REICH, 1949/1973c, p. 115-116, tradução nossa).

Em suma, a contradição que seria vivenciada pelo indivíduo de estrutura mística - vislumbrar os fluxos plasmático-vegetativos, sem jamais experienciá-los 
“de forma direta e unificada" - apenas poderia levá-lo a supor a existência de “forças místicas, sobrenaturais” (REICH, 1944/1991a, p. 29, tradução nossa).

Além da estrutura mística e da estrutura mecanicista, Reich reconheceu a existência do "organismo desencouraçado" (REICH, 1949/1973c, p. 58, tradução nossa) ou, segundo a expressão que cunhara em seu período psicanalítico, do genitale Charakter (“caráter genital”) (REICH, 1933/1969, p. 187, tradução nossa).

\subsection{Estrutura não encouraçada}

Para Reich, a estrutura de caráter desencouraçada (ou caráter genital) teria como característica central o acesso à "convulsão orgástica", o "principal enraizamento do ser humano na natureza" (REICH, 1951/1973b, p. 284, tradução nossa). Nesse estilo de estruturação, não haveria bloqueios entre o "estrato biológico profundo" (o conjunto das motilidades plasmáticas celulares) e a "superfície psíquica", de forma que as "emoções biológicas" (as correntes vegetativas) poderiam "fluir livremente" do "núcleo em direção à periferia" (REICH, 1950/1990e, p. 1, tradução nossa).

Devido a esse "sistema plasmático em livre fluxo" (REICH, 1949/1973c, p. 58, tradução nossa), o indivíduo não encouraçado perceberia os estímulos e reagiria a eles de forma diferenciada, estabelecendo um contato fenomênico direto e vívido que em nada se assemelharia ao bloqueio perceptivo da estrutura mecanicista ou às experiências patológicas projetivas, da estrutura mística: “o caráter genital irá se sentir bem, feliz, e bastante coordenado sob o impacto da corrente orgonótica" (REICH, 1949/1973h, p. 433, tradução nossa). Esse contato cristalino (nem amortecido, nem enevoado) do sujeito desencouraçado com suas 
sensações plasmáticas, abriria, na visão reichiana, possibilidades ímpares de entendimento da própria vida, da natureza e da sociedade. Poder-se-ia até mesmo reconhecer na "vida desencouraçada" - como anotou o autor em seu diário, em 05 de agosto de 1945 - um toque de genialidade, desde que se entendesse por genialidade a "ampla e natural expansão de um ser”: “o oposto disso é o indivíduo limitado, ‘encarcerado', aprisionado” (REICH, 1999, p. 299, tradução nossa).

Fator central, de acordo com o autor, para o bem-estar do indivíduo, a sensação plasmática seria, também, essencial para o trabalho do pesquisador, representando "o instrumento mais importante da investigação científico-natural" (REICH, 1949/1973c, p. 61, tradução nossa, grifo do autor). Por estar consciente do potencial da sensorialidade plasmática para traduzir a motilidade não mecânica de certos fenômenos, o cientista desencouraçado trataria suas sensações de órgão com bastante cuidado, "da mesma forma que um bom carpinteiro cuida de sua plaina". Esse pesquisador sempre procuraria coadunar sua "atividade intelectual" com "suas 'sensações"”, mantendo-se atento aos "sutis avisos" de sua sensorialidade, pois tais sinais poderiam the indicar se seu pensamento estaria "certo ou errado", "claro ou turvado por interesses pessoais", modelado por "inclinações irracionais ou processos objetivos." Nada disso teria a ver com "misticismo", mas tão somente, com a tentativa de manter "em boas condições" o aparato sensorial em sua função de instrumento de pesquisa. Essa calibragem não seria resultado de um “'dom”” ou “'talento' especial”, mas de um exercício contínuo de "autocrítica e autocontrole". Pois a atividade científica requereria, do pesquisador, não apenas “um límpido sistema sensorial”, mas também a capacidade de "clareá-lo" caso esse sistema viesse a se tornar "irracionalmente distorcido" (p. 96, tradução nossa). 
Com essa afinação perceptiva, o pesquisador teria mais chances de se inteirar da motilidade funcional (não mecânica, espontânea) de seu objeto de estudo, estabelecendo, assim, uma espécie de empatia. Pois, se o distanciamento defensivo (estrutura mecanicista) e o espelhamento distorcido (estrutura mística) em relação às sensações vegetativas seriam duas características centrais do encouraçamento, a atitude empática de base plasmática representaria um dos elementos essenciais, segundo Reich, da vida desencouraçada, como veremos a seguir.

\subsubsection{A função da empatia}

Em um texto enxertado em 1949 no livro Character analysis - "The expressive language of the living" (A linguagem expressiva da vida) -, Reich fez algumas referências à dimensão empática do contato humano. Apresentando importantes fundamentos de seu terceiro método terapêutico (a orgonoterapia), ele ponderou que "apenas quando tivermos sentido a expressão facial do paciente estaremos em condições de compreendê-la". O termo "compreender", realçou o autor, significaria "literalmente saber qual é a emoção que está se manifestando naquela expressão facial", ou seja, qual é o estado ou grau de mobilidade protoplasmática que o rosto traduz. Não faz diferença, ponderou o autor, "se a emoção é móvel e ativa, ou se é imóvel e contida", pois o que importa, a seu ver, é a apreensão da condição plasmática: "Precisamos aprender a reconhecer a diferença entre uma emoção móvel e uma emoção contida" (REICH, 1949/1973g, p. 362, tradução nossa, grifos do autor). 
Retomando, no último livro por ele publicado - Contact with space ("Contato com o espaço"), de 1957 - a importância desse contato empático mediado pelas sensações ou impressões de órgão, o autor descreveu a situação em que um indivíduo, em busca de tratamento para um incômodo sintoma corporal, consulta vários médicos, sem obter deles uma solução para o seu enigmático desconforto; ainda com esperanças de encontrar uma saída para o seu sofrimento, ele resolve procurar um orgonoterapeuta. Reich relatou os procedimentos iniciais que ele costumava adotar em casos como esses e em outros, semelhantes, que impunham alto grau de dificuldade:

A primeira coisa a fazer em tais situações é relaxar, sentar-se, olhar o paciente, conversar com ele e saber que 'impressão' ele nos dá (get 'the feel' of him), impressão essa que é desdenhada tanto por 'cientistas exatos', quanto pela 'psicologia' ou pelo 'misticismo' (REICH, 1957, p. 11, tradução nossa, grifo do autor).

Essa atitude empática se manifestaria, por vezes, de forma mimética: “os movimentos expressivos do paciente eliciam involuntariamente uma imitação em nosso próprio organismo. Imitando esses movimentos, nós 'sentimos' e compreendemos a expressão em nós mesmos e, consequentemente, no paciente". Partindo do pressuposto de que toda expressão indicaria uma "condição emocional do protoplasma", Reich acreditava, como comentamos logo acima, que "a linguagem da expressão facial e corporal" do paciente representaria uma via privilegiada de acesso às suas “emoções”, ou seja, ao grau de motilidade plasmática: “Quando falamos de 'atitude caracterial' estamos nos referindo à expressão global de um organismo. Essa expressão é literalmente idêntica à 
impressão global que o organismo provoca em nós" (REICH, 1949/1973g, p. 362, tradução nossa, grifos do autor).

\subsection{Considerações gerais}

Pudemos observar que haveria, no entendimento reichiano, uma instância denominada pelo autor, entre outras caracterizações, de estrutura biopsíquica que determinaria a atitude geral do indivíduo em relação às suas próprias sensações de órgão: distanciamento radical (estrutura mecanicista), distorção projetiva (estrutura mística), aproximação vívida (estrutura desencouraçada). Convicto de que a estrutura mecanicista e a estrutura mística seriam predominantes no mundo atual, o autor procurou compreender, também, como esses estilos de organização biopsíquica influenciariam o trabalho do profissional de ciência, especialmente dos cientistas que estariam, na avaliação reichiana, sob forte efeito da concepção de mundo mecano-materialista.

Distanciado, na avaliação reichiana, do principal indicador corpóreo do movimento espontâneo - as sensações plasmáticas -, o pesquisador de estrutura mecanicista ficaria agarrado às ranhuras da substância, tentando decifrar seus mínimos detalhes e se protegendo, assim, do contato direto com os aspectos irregulares e contraditórios dos fenômenos. Pois, para garimpar leis científicas gerais em terrenos movediços ou instáveis seria preciso que o pesquisador sobrepujasse, de acordo com Reich, sua "angústia orgástica" (o temor da motilidade vegetativa espontânea). Caso contrário, a estrutura mecanicista dificilmente acessaria a lógica 'funcional' dos fenômenos, em que a propriedade do 
automovimento desempenha importante papel. O encouraçamento, como salientou o autor, representaria o reverso da motilidade espontânea.

Outro tipo de funcionamento bastante comum, seria, na visão reichiana, a estrutura mística. Com essa designação o autor não estava se referindo a uma preferência pessoal (por temas esotéricos, por exemplo), mas a uma remodelação do funcionamento global do indivíduo que alcançaria e perturbaria o estrato profundo da motilidade espontânea. Estabelecendo contraposições entre a estrutura mecanicista e a estrutura mística, o cientista chegou à conclusão que esta última, diferentemente da primeira, estabeleceria alguma aproximação com as móveis correntes vegetativas. Tratar-se-ia, porém, de um contato espelhado ou enevoado, visto que a couraça da estrutura mística impediria que o indivíduo reconhecesse suas sensações plasmáticas como acontecimentos inerentes à própria corporalidade; distorcidas, as percepções dos fluxos vegetativos se converteriam em fantasmagorias que o sujeito atribuiria a instâncias suprafísicas.

Por mais que as estruturas mecanicistas contribuíssem continuamente para um melhor entendimento de uma ampla gama de fenômenos (inclusive, acerca das minúcias da matéria) e as estruturas místicas sempre denunciassem as limitações da dureza materialista, ambas compartilhariam, mesmo que inconsciente e involuntariamente, de certa crueldade em relação ao vivo: as estruturas mecanicistas porque se esqueceriam, com frequência, de que os seres humanos não podem ser tratados como máquinas, e as estruturas místicas porque poderiam recorrer, por vezes, à uma intensa agressividade na tentativa de apalpar o espelhamento da motilidade.

Partindo do pressuposto de que a sensação de órgão representaria o principal indicador da existência de processos energéticos primários (funcionais ou 
automoventes, na linguagem técnica reichiana), o autor tentou demonstrar que o pesquisador mecano-materialista, por conta da paralisia de sua própria motilidade sensorial, não conseguiria alcançar certos estratos dinâmicos da realidade. Estaria vedado a ele, em especial, os estratos que teriam relação direta, no entendimento reichiano, com o automovimento da energia orgone; distante dessa dimensão 'funcional', o cientista mecano-materialista precisaria se limitar aos aspectos superficiais e quantitativos dos acontecimentos. O indivíduo de estrutura mística, por sua vez, ainda que tivesse algum contato com suas sensações de fluxo, pouco ou nada contribuiria para um melhor entendimento científico do movimento plasmático espontâneo ou do automovimento dos fenômenos externos, pois sua couraça não lhe permitiria reconhecer a concretude objetiva da pulsação orgonótica e faria, assim, com que ele atribuísse a entidades suprafísicas acontecimentos 'funcionais' estritamente objetivos.

Reich era da opinião, contudo, que o cientista não encouraçado teria chances de enxergar para além da causalidade mecânica e examinar as propriedades funcionais automoventes, tanto na natureza inorgânica, quanto na natureza viva. Por vivenciar a intensa experiência da convulsão orgástica, o pesquisador desencouraçado não temeria suas sensações plasmáticas, tendo mais chances, assim, de captar sinais do automovimento orgonótico, nele próprio e externamente a ele, e desenvolver uma atividade científica 'funcional' ou não mecanicista.

Para o autor, a pesquisa científica estaria, em suma, diretamente associada à estrutura de funcionamento do pesquisador, estrutura essa que seria definida, basicamente, pelo tipo de contato que o indivíduo estabelece com suas sensações vegetativas. As estruturas mecanicistas, apesar do bloqueio de suas sensações de 
órgão, realizariam pesquisas extremamente relevantes, que não alcançariam, porém, os estratos orgonóticos profundos (espontâneos) da realidade; as estruturas místicas, com sua espiritualização das sensações de órgão, pouco ou nada contribuiriam para a pesquisa científica objetiva, mas cumpririam importante papel ao denunciar os limites do pensamento mecano-materialista; as estruturas não encouraçadas, por apresentarem contato direto e sem ruídos com suas sensações de órgão, teriam, por sua vez, mais chances de chegar aos níveis operacionais funcionais (não mecânicos e automoventes). 


\section{CONCLUSÃO}

“O QUE É A SENSAÇÃO? COMO A MATÉRIA PODE CHEGAR A PERCEBER A SI PRÓPRIA? DE QUE A SENSAÇÃO É TRIBUTÁRIA? EM QUE CONDIÇÕES A SENSAÇÃO SE APRESENTA E EM QUE CONDIÇÕES ELA NÃO SE FAZ PRESENTE?"

(W. Reich, 1949 - Ether, God and Devil). 
Empenhamo-nos em resgatar, nos capítulos anteriores, as principais asserções reichianas sobre o funcionamento sensorial e prospectar suas raízes científicas e filosóficas. Assim procedendo, procuramos contribuir para ampliar o entendimento sobre as pesquisas sensorialistas de Reich, pesquisas essas que, embora basilares em sua produção, permanecem pouco conhecidas ou discutidas. Teceremos agora, a título de finalização, algumas reflexões gerais suscitadas pelo presente estudo.

Salta aos olhos, antes de tudo, justamente o papel fundamental que o tema da sensação ocupou no conjunto da obra do cientista. Tivemos oportunidade de notar, ao longo deste trabalho, que o problema da sensorialidade não apenas permeou, por quase quatro décadas, as investigações clínico-terapêuticas, experimentais e epistemológicos reichianas, como também atuou como elemento articulador desses três setores. Por isso, os estudos de Reich sobre a sensação assumem, a nosso ver, lugar de destaque em sua produção e ocupam o mesmo patamar de outras pesquisas-chave do autor, tais como as que ele dirigiu à questão da energia e à epistemologia da produção científica.

Chama atenção, também, o fato de o cientista ter adotado, como elemento de base de suas investigações sensorialistas, um tipo específico de percepção, ao qual ele atribuiu, como vimos, quatro distintas, porém correlatas denominações: sensação plasmática, sensação vegetativa, sensação de órgão e sensação orgonótica. Para Reich, a sensação de órgão era de suma importância, pois ela representaria a tradução psíquica mais cristalina dos pulsos e fluxos plasmáticos, teria potencial para relembrar ao ser humano sua origem animal (protoplasmática), 
seria um elemento indispensável da potência orgástica, funcionaria como antídoto às seduções mecanicistas e espiritualistas e desempenharia importante função na produção do conhecimento, inclusive, do saber científico. Pode-se dizer ainda que, com seus multifacetados estudos (clínico-terapêuticos, experimentais, epistemológicos) sobre as sensações plasmáticas humanas, o autor trouxe um novo olhar para um tipo de percepção ou vivência (como as sensações de corrente) que não raramente desponta nas práticas diretamente voltadas ao movimento do corpo (danças, artes marciais, atividades esportivas), nas assim chamadas terapias corporais, em determinados estados de bem-estar e mesmo em algumas condições patológicas, e, como realçou o autor, em certas experiências eróticas.

Adotando a sensação plasmático-vegetativa como unidade de análise, o autor acabou realizando uma pesquisa de amplo espectro que articulou dois aspectos extremos da sensorialidade: suas matrizes biológicas e cósmicas, por um lado, e seu papel na construção humana do conhecimento, por outro. Concebendo a sensação plasmática como uma característica básica da matéria viva (decorrente da coligação entre energia orgone e substância protoplasmática) e não apenas como um fenômeno específico de seres humanos ou de organismos dotados de sistema nervoso, Reich também procurou demonstrar que, no campo do humano, esse gênero de apreensão sensorial seria continuamente modelado por uma estrutura caracterial construída historicamente na relação dialética indivíduosociedade.

Merece destaque, ainda, outro aspecto singular da teoria sensorialista reichiana: seu caráter simultaneamente perspectivista e alinhavador. Ainda que tivesse circulado por distintas áreas do conhecimento (Biologia, Psicologia, Epistemologia, entre outras), o autor, rebelando-se contra a rígida 
compartimentalização dos saberes e mantendo-se fiel a um aspecto central de sua metodologia de pesquisa, apostou na existência de um princípio fenomênico unificador que integrasse desde o funcionamento unicelular até a atividade intelectual humana. O cientista apresentou esse fator comum no quadro de sua teoria das emoções, propondo que as espontâneas direções de movimento do plasma (as emoções, de acordo com a terminologia orgonômica) e suas concomitantes sensações comporiam uma motilidade sensorial que, além de se fazer presente no organismo unicelular, seria um ingrediente fundamental (como sensações de órgão) na formação e exercício do intelecto humano. Ambas as asserções - de que haveria uma motilidade sensorial em micro-organismos e de que esse mesmo gênero de sensorialidade seria fundamental para o pensamento humano e sua orientação epistêmica - são tão ousadas, quanto polêmicas, e mereceriam, a nosso ver, análises multidisciplinares mais aprofundadas.

Examinando as proposições sensorialistas do autor, não é possível deixar de notar sua tentativa de enraizar em termos bioenergéticos (ou, dito em linguagem reichiana mais precisa, em termos de pulsatilidade plasmática orgonótica) não apenas os fenômenos da sensação e percepção, mas também o orgasmo, a emoção e a expressão emocional. Frequentemente considerado o pai de algumas psicoterapias corporais, Reich, sem jamais desconsiderar o crucial papel do psiquismo na existência humana, parecia estar mais interessado, em especial no estágio orgonômico de sua produção, em contribuir para a construção de uma bioterapia, ou seja, uma abordagem clínica que acessasse, da forma mais direta possível, as disfunções da motilidade plasmático-vegetativa. Com o método da orgonoterapia, o autor pretendia, de acordo com sua peculiar conceituação, alcançar as perturbações emocionais (os entraves das movimentações plasmáticas e 
de sua expressão periférica), as disfunções percepto-sensoriais (os bloqueios e distorções das sensações de órgão) e, especialmente, a impotência orgástica (a paralisação global da pulsatilidade plasmática).

O papel da sensorialidade plasmático-vegetativa no desenvolvimento psíquico do recém-nascido e da criança pequena representa, em nosso entendimento, outra promissora diretriz investigativa reichiana. Nesse contexto, são bastante originais as tentativas do autor, que apenas esboçamos aqui, de correlacionar a desintegração do pensamento, em certos casos de esquizofrenia, a possíveis perturbações vivenciadas na primeira infância durante o processo de integração das sensações de órgão da criança.

Por meio de inovadoras pesquisas, direções investigativas e plataformas de análise, o autor ofereceu, sem dúvida, novos elementos teóricos, experimentais e epistemológicos para o estudo da sensorialidade. Com o presente trabalho empreendemos algumas aproximações com esse peculiar e polêmico percurso reichiano - um percurso que, parece-nos, ainda tem muito a ser explorado. Alguns temas que apenas pudemos abordar de forma panorâmica - como as proposições reichianas sobre o mecanicismo e o misticismo, a sensorialidade dos unicelulares e a base sensorial do psiquismo -, também mereceriam, a nosso ver, análises mais detalhadas, dado seu potencial para suscitar, em uma contemporaneidade que parece pouco disposta a se embrenhar nas searas da Teoria do Conhecimento, discussões simultaneamente científicas e epistemológicas. Seriam igualmente valiosas, em nossa opinião, eventuais pesquisas que estabelecessem contrastes críticos entre as asserções sensorialistas reichianas e outros estudos sobre o funcionamento percepto-sensorial. 
Em suma, são muitas e diversas, a nosso ver, as implicações decorrentes das teorias de Reich sobre a sensação, embora não tenhamos tido a oportunidade de começar a explorá-las aqui, dado nosso propósito de, essencialmente, recuperar e circunscrever tais teorias. O autor desta tese tem, aliás, a sensação (!) de ainda estar bastante impactado pelas asserções sensorialistas reichianas e que passará um bom tempo digerindo suas implicações científicas, filosóficas e terapêuticas.

Esperamos, no entanto, ter apontado, com a presente pesquisa, o papel central da sensorialidade na produção reichiana e as contribuições do cientista para o conjunto de investigações que, de longa data, vêm procurando compreender o intrigante fenômeno da apreensão sensorial. 


\section{REFERÊNCIAS}

ALBERTINI, P. Reich - História das ideias e formulações para a educação. São Paulo: Ed. Ágora, 1994.

ARAUJO, S. F. A fundamentação filosófica do projeto de uma psicologia científica em Wilhelm Wundt. 2007. Tese (doutorado) - Instituto de Filosofia e Ciências Humanas, Universidade Estadual de Campinas, São Paulo, 2007.

ARAUJO, S. F. Uma visão panorâmica da psicologia científica de Wilhelm Wundt. Scientiae Studia, São Paulo, v. 7, n. 2, p. 209-20, 2009.

BAIN, A. The senses and the intellect. London: Jonh W. Parker and Son, 1855.

BAKER, C. F. Atmospheric pulsation: Air and water. Annals of the Institute for Orgonomic Science, v. 2, n. 1, p. 25-32, September 1985.

BAKER, C. F. Energy: An overview. Annals of the Institute for Orgonomic Science, v. 4, n. 1, p. 1-14, September 1987.

BEALE, L. S. Protoplasm; or, life, matter and mind. London: J. Churchill \& Sons, 1870.

BEAN, O. Me and the orgone. Princeton: The American College of Orgonomy Press, 2000. (Trabalho original publicado em 1971).

BEDANI, A. Energética e epistemologia no nascimento da obra de Wilhelm Reich. 2007. 177 f. Dissertação (Mestrado) - Instituto de Psicologia, Universidade de São Paulo, São Paulo, 2007(a).

BEDANI, A. O impacto das teorias mnemônicas de Richard Semon na obra reichiana. Pensamento Reichiano em Revista, v. 2, p. 33-66, 2007(b).

BEDANI, A.; ALBERTINI. P. Política e sexualidade na trajetória de Reich: Berlim (19301933). Arquivos Brasileiros de Psicologia, v. 61, n. 2, 2009. Disponível em: <http://146.164.3.26/seer/lab19/ojs2/index.php/ojs2/article/viewArticle/499/323> . Acesso em: $20 \mathrm{fev} .2011$. 
BEDANI, A.; ALBERTINI, P. Política e sexualidade na trajetória de Reich: Viena (1927-1930). Encontro - Revista de Psicologia, v. 11, n. 14, p. 62-77, jul-dez 2006.

BENAROYO, L. La renaissance de la pensée biologique de Rudolf Virchow dans l'oeuvre de Ludwig Aschoff. Revue d'histoire des sciences, tome 50, n. 4, p. 447-60, 1997.

BERGSON, H. Essai sur les données immédiates de la conscience. In: Henri Bergson Oeuvres. Paris: Presses Universitaires de France, 1984(a). (Trabalho original publicado em 1889).

BERGSON, H. L'evolution créatrice. In: Henri Bergson - Oeuvres. Paris: Presses Universitaires de France, 1984(b). (Trabalho original publicado em 1907).

BERNARD, C. Leçons sur les phénomènes de la vie communs aux animaux et aux végétaux. Paris: Librairie J.-B. Baillière et fils, 1879.

BINET, La vie psychique des micro-organismes. In: Études de psychologie expérimentale. Paris: Octave Doin, Éditeur, 1888.

BORDENAL, P. The Surface and the Abyss: Nietzsche as Philosopher of Mind and Knowledge (Monographien Und Texte Zur Nietzsche-Forschung). Berlin/New York: Walter de Gruyter GmbH \& Co. KG, 2010

BRAID, B.; DEW, R. Reich's bioelectric experiments: A review with recent data. Annals of the Institute for Orgonomic Science, v. 5, n. 1, p. 1-18, September 1988.

CAPONI, G. A marcha da natureza e seus descaminhos. Revista Ciência Hoje, jul. 2009.

CAREY, K.; DUNLAP, S. Culturing SAPA bions. The Journal of Orgonomy, v. 22, n. 1, p. 6875, may 1988.

CASSIRER, E. Substance and function \& Einstein's theory of relativity. Tradução de William C. Swabey, Marie C. Swabey. New York: Dover Publications, 1953. (Trabalhos originais publicados em 1910 e 1921).

CAYGILL, H. Dicionário Kant. Tradução de Álvaro Cabral. Rio de Janeiro: Jorge Zahar Editor, 2000.

CLARK, E.; JACYNA, L. S. Nineteenth century origins of neuroscientific concepts. University of California Press, 1987. 
CORREA, J. D. V. Historia de la célula. La teoría celular en los orígenes de la biología moderna. Chile: Editorial Universitaria, 1998.

DALGALARRONDO, P. Evolução do cérebro - Sistema nervoso, psicologia e psicopatologia sob a perspectiva evolucionista. Porto Alegre: Ed. Artmed, 2011.

DIDEROT, D. Oeuvres Complètes de Diderot. Belles-Lettres VI - Poésies diverses. Sciences Mathématiques, Physiologie. Liechtenstein: Kraus Reprint Lda, 1966.

DILTHEY, W. Historia de la filosofia. Tradução de Eugenio Ímaz. México: Fondo de Cultura Económica, 1992. (Trabalho original publicado em 1949).

DUJARDIN, F. Mémoire sur l'organisation des infusoires. Annales des sciences naturelles, Seconde Série, Tome Dixième, Zoologie, Paris, Crochard \& Cie, Libraires-Éditeurs, 1838.

FELTZ, B. Le réductionnisme en biologie. Approches historique et épistémologique. Revue Philosophique de Louvain, v. 93, n. 93-1-2, p. 9-32, 1995.

FIGUEIREDO, L. C. M.; DE SANTI, P. L. R. Psicologia - Uma (Nova) Introdução. São Paulo: EDUC, 2004.

FLOURENS, P.-M.-J. Recherches expérimentales sur les propriétés et les fonctions du système nerveux, dans les animaux vertébrés. Paris: Chez Crevot, Libraire-Éditeur, 1824.

FOKIN, S. I. A brief history of ciliate studies (late XVII - the first third of the XX century). Protistology, 3 (4), p. 283-96, 2004. Disponível em: <http://protistology.ifmo.ru/num3_4/fokin.pdf> Acesso em: 11 jul. 2011.

FREEDHEIM, D. K.; WEINER, I. B. (Eds.). Handbook of Psychology: Volume 1 - History of Psychology. New Jersey: John Wiley \& Sons, Inc., 2003.

FREUD, S. Las neuropsicosis de defensa. In: Sigmund Freud - Obras Completas. Tomo 1. Tradução de Luis Lopez-Ballesteros y de Torres. Madrid: Editorial Biblioteca Nueva, 1973(a). (Trabalho original publicado em 1894).

FREUD, S. Tres ensayos para una teoria sexual. In: Sigmund Freud - Obras Completas. Tomo 2. Tradução de Luis Lopez-Ballesteros y de Torres. Madrid: Editorial Biblioteca Nueva, 1973(b). (Trabalho original publicado em 1905). 
GARCIA, A. L. M. Metáforas do corpo: reflexões sobre o estatuto da linguagem na filosofia do jovem Nietzsche. 208 f. Dissertação (Mestrado) - Instituto de Filosofia e Ciências Humanas - Programa de Pós-Graduação em Filosofia, Universidade Estadual de Campinas, São Paulo, 2008.

GEISON, G. L. The protoplasmic theory of life and the vitalist-mechanist debate. Isis, v. 60, n. 3, p. 272-92, 1969.

GOETHE, J. W. Oeuvres d'histoire naturelle de Goethe. Tradução de Ch. Fr. Martins. Paris: AB. Cherbuliez et Co. Libraires, 1837.

GOODWIN, C. J. História da psicologia moderna. Tradução de Marta Rosas. São Paulo: Editora Cultrix, 2010.

HAECKEL, E. Freedom in science and teaching. New York: Appleton and Company, 1879.

HAECKEL, E. Monism as connecting religion and science. The confession of faith of a man of science. Tradução de J. Gilchrist. London: Adam and Charles Black, 1895.

HALL, T. S. The scientific origins of the protoplasm problem. Journal of the history of ideas, v. 11, n. 3, p. 339-356, jun. 1950.

HERSCHEL, W. A preliminary discourse on the study of natural philosophy. London: Longman, Orme, Brown, Green \& Longmans, 1840. (Trabalho original publicado em 1831).

HIGGINS, M.; RAPHAEL, C. (Org.) Reich speaks of Freud. London: Condor Book, 1972. HOTHERSALL, D. História da psicologia. (4 ${ }^{\text {a }}$ ed.). Tradução de Elaine Pepe, Eliane Fittipaldi. São Paulo: Ed. McGraw-Hill, 2006.

HUGHES, A. A History of Cytology. London: Abelard-Schuman, 1959.

HUGHES, D. C. Some Geiger-Müller counter observations after Reich. The Journal of Orgonomy, v. 16, n. 1, p. 68-73, may 1982.

HUXLEY, T. H. On the physical basis of life. New Haven: C.C. Chatfield, 1870. 
KANT, E. Critique da la raison pure. Tradução de A. Tremesaygues, B. Pacaud. Paris: Presses Universitaires de France, 2001.

LAMARCK, J.-B. Recherches sur l'organisation des corps vivans, 1802. Texto integral contido no website CEuvres et rayonnement de Jean-Baptiste Lamarck, Plateforme technologique du CRHST-CNRS, disponível em: http: / /www.lamarck.cnrs.fr/. Acesso em: 17 jan. 2012.

LANGE, A. F. Histoire de matérialisme (Tome premier). Tradução de B. Pommerol. Paris:

Chez C. Reinwald et Cie., Llbraires-Éditeurs, 1877. (Trabalho original publicado em 1865).

LANGE, A. F. Histoire de matérialisme (Tome seconde). Tradução de B. Pommerol. Paris: Chez C. Reinwald et Cie., Llbraires-Éditeurs, 1879. (Trabalho original publicado em 1865).

LANGE, A. F. The history of materialism and criticism of its present importance. ( $3^{. \mathrm{a}} \mathrm{ed}$.). Tradução de Ernest C. Thomas. London: Routledge \& Kegan Paul Ltd., 1950. (Trabalho original publicado em 1865).

LISPECTOR, C. Perto do Coração Selvagem. Rio de Janeiro: Rocco, 1998. (Trabalho original publicado em 1943).

MARTINS, L. P. A teoria da progressão dos animais de Lamarck. 1993. 403 f. Dissertação (Mestrado) - Instituto de Biologia, Universidade Estadual de Campinas, 1993.

MATTHIESEN. S. Q. A educação em Wilhelm Reich - Da psicanálise à pedagogia econômicosexual. São Paulo: Editora Unesp, 2003.

MAYR, E. Isto é biologia: a ciência do mundo vivo. Tradução de C. Ângelo. São Paulo: Companhia das Letras, 2008.

MEGLHIORATTI, F. A.; CALDEIRA, A. M. A.; BORTOLOZZI, J. Recorrência da ideia de progresso na história do conceito de evolução biológica e nas concepções de professores de biologia: interfaces entre produção científica e contexto sociocultural. Filosofia e História da Biologia, vol. 1, p.107-23, 2006.

MERLEAU-PONTY, M. La nature - Notes. Cours du Collège de France (Établi et annoté par Dominique Séglard). Éditions du Seuil, 1995.

MOORE, G. Nietzsche, biology and metaphor. Cambridge University Press: 2002. 
NASSELSTEIN, P. The Discovery of the Orgone Energy - 1919-1939. Orgonomie.net, 2007. Disponível em: <www.orgonomie.net>. Acesso em 22 abr. 2012.

NIETZSCHE, F. A gaia ciência. Tradução de Paulo César de Souza. São Paulo: Cia. das Letras, 2001. (Trabalho original publicado em 1882 e ampliado em 1887).

OLIVEIRA E SILVA, J. R. O desenvolvimento da noção de caráter no pensamento de Reich. 2001. 149 f. Dissertação (Mestrado) - Instituto de Psicologia, Universidade de São Paulo, São Paulo, 2001.

OLLENDORFF DE REICH, I. Wilhelm Reich: Una biografia personal. Tradução de Julio Crespo. Barcelona: Gedisa, 1978.

ORGONE INSTITUTE PRESS. WILHELM REICH: BIOGRAPHICAL MATERIAL. History of the discovery of the life energy (European and American Period, 1920-1952), documentary volume A-IX-B. Bibliography on orgonomy. Rangeley, Maine: Orgone Institute Press, 1953.

OTIS, L. Networking: Communicating with bodies and machines in the nineteenth century. University of Michigan: 2004.

PASCAL, G. Compreender Kant. Tradução de Raimundo Vier. Rio de Janeiro: Vozes, 2008.

PEIRCE, C. S. Semiótica. Tradução de José Teixeira Coelho Neto. São Paulo: Ed. Perspectiva, 2000.

PESSOA, F. O guardador de rebanhos e outros poemas - Poesia completa de Alberto Caeiro. São Paulo: Landy Editora, 2006.

PIGNATARI, D. Semiótica \& Literatura. São Paulo: Ateliê Editorial, 2004.

PLACZEK, B. R. (Ed.) Record of a friendship - The correspondence of Wilhelm Reich and A. S. Neill. New York: Farrar, Strauss \& Giroux, 1981.

QUEIROZ, J. Semiose segundo C.S. Peirce. São Paulo: Educ-Fapesp, 2004.

REICH, W. Massenpsychologie des Faschismus. Kopenhagen - Prag - Zürich: Verlag für Sexualpolitik, 1933.

REICH, W. Experimental orgone therapy of the cancer biopathy (1937-1943). International Journal of Sex-Economy and Orgone-Research, v. 2, n. 1, p. 1-92, March 1943. 
REICH, W. Anorgonia in the carcinomatous shrinking biopathy. International Journal of Sex-Economy and Orgone-Research, v. 4, n. 1, p. 1-33, April 1945.

REICH, W. Preface to the third edition. In: .The mass psychology of fascism. Tradução de Theodore P. Wolfe. New York: Orgone Institute Press, 1946(a). (Prefácio redigido em 1945).

$\mathrm{REICH}, \mathrm{W}$. The biological miscalculation in the human struggle for freedom. In: . The mass psychology of fascism. Tradução de Theodore P. Wolfe. New York: Orgone Institute Press, 1946(b). (Trabalho original publicado em International Journal of Sex-Economy and Orgone-Research, v. II, n. 2-3, p. 97-121, September 1943).

REICH, W. The mass psychology of fascism. Tradução de Theodore P. Wolfe. New York: Orgone Institute Press, 1946(c).

REICH, W. Orgonometric Equations: I. Geral Form. Orgone Energy Bulletin, v.2, n. 4, p. 161-183, October 1950(a). (Capítulos 1-10 de texto redigido em maio de 1949).

REICH, W. Orgonomic functionalism. Part II. On the historical development of orgonomic functionalism. Tradução de Myron R. Sharaf. Orgone Energy Bulletin, v.2, n.1, p. 1-15, January 1950(b).

REICH, W. Orgonomic functionalism. Part II. On the historical development of orgonomic functionalism (Cont.). Tradução de Myron R. Sharaf. Orgone Energy Bulletin, v.2, n. 2, p. 49-62, April 1950(c).

REICH, W. Orgonomic functionalism. Part II. On the historical development of orgonomic functionalism (Cont.). Tradução de Myron R. Sharaf. Orgone Energy Bulletin, v.2, n. 3, p. 99-123, July 1950(d).

REICH, W. Contact with space. Oranur - Second Report. 1951-1956. New York: Core Pilot Press, 1957.

REICH, W. Charakteranalyse - Technik und Grundlagen für studierende und praktizierende Analytiker. Verlag De Munter Amsterdam, 1969. (Obra original publicada em 1933). 
REICH, W. Character analysis. Tradução de Vincent R. Carfagno. London: Vision Press, 1973(a). (Trabalho original publicado em 1933 e ampliado em 1945 e 1949).

REICH, W. Cosmic Superimposition. In: Ether, God and Devil. Cosmic

Superimposition. Tradução de Therese Pol. New York: Farrar, Strauss \& Giroux, 1973(b). (Trabalho original publicado em 1951).

REICH, W. Ether, God and Devil. In: Ether, God and Devil. Cosmic

Superimposition. Tradução de Therese Pol. New York: Farrar, Strauss \& Giroux, 1973(c). (Trabalho original publicado em 1949).

REICH, W. Psychic contact and vegetative current. In: Character analysis. Tradução de Vincent R. Carfagno. London: Vision Press, 1973(d). (Trabalho original: Psychischer Kontakt und vegetative Strömung. Abhandlungen zur personellen Sexualökonomie $N^{o}$ 3, Sexpol Verlag, 60 p., 1935; republicado em 1945 na segunda edição de Character analysis).

REICH, W. The Cancer Biopathy: Volume 2 of The Discovery of the Orgone. Tradução de Andrew White. New York: Farrar, Strauss \& Giroux, 1973(e). (Trabalho original publicado em 1948).

REICH, W. The emotional plague. In: Character analysis. Tradução de Vincent R. Carfagno. London: Vision Press, 1973(f). (Trabalho original publicado no International Journal of Sex-Economy and Orgone-Research, v. 4, n. 1, p. 34-53, April 1945; republicado em 1949 na terceira edição de Character analysis).

$\mathrm{REICH}, \mathrm{W}$. The expressive language of the living. In: Character analysis. Tradução de Vincent R. Carfagno. London: Vision Press, 1973(g). (Redigido no inverno de 1948 e publicado em 1949 na terceira edição de Character analysis).

REICH, W. The schizophrenic split. In: Character analysis. Tradução de Vincent R. Carfagno. London: Vision Press, 1973(h). (Trabalho concebido no período 1940-1948, redigido entre agosto e setembro de 1948 e publicado em 1949, na terceira edição de Character analysis).

REICH, W. Further remarks on the therapeutic significance of genital libido. In: Early writings - Volume One. Tradução de Philip Schmitz. New York: Farrar, Strauss \& Giroux, 1975(a). p. 199-221. (Trabalho original publicado em 1925). 
REICH, W. The impulsive character - A psychoanalytic study of ego pathology. In:

Early writings - Volume one. Tradução de Philip Schmitz. New York: Farrar, Strauss \& Giroux, 1975(b). p. 237-332. (Trabalho original publicado em 1925).

REICH, W. The murder of Christ. Great Britains: Souvenir Press (Educational \& Academic) Ltd, 1975(c). (Trabalho original publicado em 1953).

REICH, W. Deux types narcisiques. In: - Premiers Écrits 1. Tradução de J. Chavy, D. Deisen. Paris: Ed. Payot, 1976(a). p. 154-167. (Trabalho original publicado em 1922).

REICH, W. People in trouble. Volume two of the emocional plague of makind. Tradução de Philip Schmitz. New York: Farrar, Straus and Giroux, 1976(b). (Trabalho original publicado em 1953).

REICH, W. Sur l'énergie des pulsions. In: - Premiers Écrits 1. Tradução de J. Chavy, D. Deisen. Paris: Ed. Payot, 1976(c). p. 154-167. (Trabalho original publicado em 1923).

REICH, W. The bion experiments. Tradução de Derek e Inge Jordan. New York: Farrar, Strauss \& Giroux, 1979. (Trabalho original publicado em 1938).

REICH, W. Genitality - In the theory and therapy of neurosis. Tradução de Philip Schmitz. New York: Farrar, Strauss \& Giroux, 1980(a). (Trabalho original publicado em 1927).

REICH, W. The function of the orgasm (part 2). Tradução de Barbara G. Koopman. The journal of orgonomy, New York, v. 14, n. 1, 1980(b). (Trabalho original publicado em 1927).

REICH, W. Sexuality and anxiety. The basic antithesis of vegetative life. In: The bioelectrical investigation of sexuality and anxiety. Tradução de Marion Faber, Derek Jordan, Inge Jordan. New York: Farrar, Strauss \& Giroux, 1982(a). (Trabalho original publicado em 1934: Der Urgegensatz des vegetativen Lebens, Zeitschrift für Politische Psychologie und Sexualökonomie, v.1, n.2, p. 125-142, 1934).

REICH, W. The bioelectrical function of sexuality and anxiety. In: . The bioelectrical investigation of sexuality and anxiety. Tradução de Marion Faber, Derek Jordan, Inge Jordan. New York: Farrar, Strauss \& Giroux, 1982(b). (Trabalho original publicado em 1937: Experimentelle Ergebnisse über die elektrische Funktion von Sexualität und Angst. Abhandlungen zur personellen Sexualökonomie. Klinische und experimentelle Berichte aus dem Institut für sexualökonomische Lebensforschung, n. 4, Kopenhagen, Prag, Zürich: Sexpol-Verlag, January 1937). 
REICH, W. The orgasm as an electrophysiological discharge. In: . The bioelectrical investigation of sexuality and anxiety. Tradução de Marion Faber, Derek Jordan, Inge Jordan. New York: Farrar, Strauss \& Giroux, 1982(c). (Trabalho original publicado em 1934: Der Orgasmus als elektrophysiologische Entladung - Abhandlungen zur personellen Sexualökonomie N.1, Kopenhagen: Verlag für Sexualpolitik, 1934.)

REICH, W. Children of the Future. Tradução de Derek e Inge Jordan, Bervely Placzek. New York: Farrar, Strauss \& Giroux, 1984(a).

REICH, W. Children of the future. In: Children of the Future. Tradução de Derek e Inge Jordan, Bervely Placzek. New York: Farrar, Strauss \& Giroux, 1984(b). [Comunicado sobre o Orgonomic Infant Research Center, proferido pelo autor na Second International Orgonomic Conference, em 25 de agosto de 1950. Trabalho original publicado em Orgone Energy Bulletin, v.2, n.4, p. 194-206, out. 1950].

REICH, W. The function of the orgasm: Volume 1 of the discovery of the orgone - Sexeconomic problems of biological energy. Great Britain: Condor Book, 1989. (Trabalho original publicado em 1942).

REICH, W. A note on "Simpathetic Understanding”. Tradução de Beverly Placzek. Orgonomic Functionalism: A journal devoted to the work of Wilhelm Reich, Rangeley, Maine, v.1, p. 75-81, 1990(a). (Publicação póstuma de texto redigido em 1946).

REICH, W. Man's roots in nature. Orgonomic Functionalism: A journal devoted to the work of Wilhelm Reich, Rangeley, Maine, v. 2, p. 50-74, 1990(b). (Publicação póstuma que transcreve conferência proferida em 1950).

REICH, W. The biological revolution from Homo Normalis to the child of the future. Tradução de Derek e Inge Jordan. Orgonomic Functionalism: A journal devoted to the work of Wilhelm Reich, Rangeley, Maine, v. 1, p. 30-74, 1990(c). (Publicação póstuma; não há informações sobre a data em que o texto foi elaborado, mas indicações no próprio material sugerem que foi redigido após 1947).

REICH, W. The developmental history of orgonomic functionalism. Tradução de Derek e Inge Jordan. Orgonomic Functionalism: A journal devoted to the work of Wilhelm Reich, Rangeley, Maine, v. 1, p. 1-29, 1990(d). (Trabalho original publicado em Orgone Energy Bulletin, v. 2, n. 1, jan. 1950, e Orgone Energy Bulletin, v. 2, n. 2, abr. 1950). 
REICH, W. The developmental history of orgonomic functionalism - Part Two. Tradução de Derek e Inge Jordan. Orgonomic Functionalism: A journal devoted to the work of Wilhelm Reich, Rangeley, Maine, v. 2, p. 1-23, 1990(e). (Trabalho original publicado em Orgone Energy Bulletin, v .2, n. 3, jul. 1950).

REICH, W. Wrong thinking kills. Orgonomic Functionalism: A journal devoted to the work of Wilhelm Reich, Rangeley, Maine, v. 2, p. 34-43, 1990(f). (Publicação póstuma de trabalho redigido em 1936).

REICH, W. Orgonotic Pulsation, Part One: The differentiation of orgone energy from electromagnetism - Presented in Talks with an Electrophysicist. Orgonomic Functionalism: A journal devoted to the work of Wilhelm Reich, Rangeley, Maine, v. 3, p. 20-63, 1991(a). (Trabalho redigido entre 1939 e 1944 e originalmente publicado em International Journal of Sex-Economy and Orgone-Research, vol. 3, n. 2-3, p. 97-150, october 1944).

REICH, W. The developmental history of orgonomic functionalism - Part Three. Tradução de Derek e Inge Jordan. Orgonomic Functionalism: A journal devoted to the work of Wilhelm Reich, Rangeley, Maine, v. 3, p. 1-19, 1991(b). (Trabalho redigido em 1947-48, originalmente publicado em Orgone Energy Bulletin, v. 4, n. 1, jan. 1952, e Orgone Energy Bulletin, v. 4, n. 4, out. 1952).

REICH, W. Orgone functions in weather formation. Tradução de Derek e Inge Jordan. Orgonomic Functionalism: A journal devoted to the work of Wilhelm Reich, Rangeley, Maine, v.4, p. 41-51, 1992(a). (Publicação póstuma de trabalho redigido em 1943 e revisado e ampliado em 1946).

REICH, W. Orgonotic Pulsation, Part Two: The differentiation of orgone energy from electromagnetism - Presented in Talks with an Electrophysicist. Orgonomic Functionalism: A journal devoted to the work of Wilhelm Reich, Rangeley, Maine, v. 4, p. 19-40, 1992(b). (Trabalho redigido entre 1939 e 1944 e originalmente publicado em International Journal of Sex-Economy and Orgone-Research, vol. 3, n. 2-3, p. 97-150, october 1944).

REICH, W. The attitude of mechanistic natural science to the life problem. Tradução de Derek e Inge Jordan. Orgonomic Functionalism: A journal devoted to the work of Wilhelm Reich, Rangeley, Maine, v. 4, p. 52-63, 1992(c). (Publicação póstuma de trabalho redigido em novembro de 1941). 
REICH, W. The developmental history of orgonomic functionalism - Part Four. Tradução de Derek e Inge Jordan. Orgonomic Functionalism: A journal devoted to the work of Wilhelm Reich, Rangeley, Maine, v. 4, p. 1-18, 1992(d). (Trabalho redigido em 1947-1948 e originalmente publicado em Orgone Energy Bulletin, v.4, n. 4, out. 1952; contém, também, material inédito).

REICH, W. Orgonomic functionalism in non-living nature - Part 1. Orgonomic Functionalism: A journal devoted to the work of Wilhelm Reich, Rangeley, Maine, v.5, p. 1-19, 1994(a). (Publicação póstuma de trabalho redigido em 1947-48).

REICH, W. The fundamental problem of form. Orgonomic Functionalism: A journal devoted to the work of Wilhelm Reich, Rangeley, Maine, v.5, p. 89, 1994(b). (Publicação póstuma de trabalho redigido em 1935).

REICH, W. Orgonomic functionalism in non-living nature - Part 2. Orgonomic Functionalism: A journal devoted to the work of Wilhelm Reich, Rangeley, Maine, v. 6, p. 1-21, 1996(a). (Publicação póstuma de trabalho redigido em 1947-48).

REICH, W. Processes of integration in the newborn and the schizophrenic. Orgonomic Functionalism: A journal devoted to the work of Wilhelm Reich, Rangeley, Maine, v. 6, p. 51-71, 1996(b). (Publicação póstuma que transcreve conferência proferida em 1949 ou 1950).

REICH, W. American odyssey - Letters and journals, 1940-1947. Tradução de Derek e Inge Jordan, Philip Schmitz. New York: Farrar, Strauss \& Giroux, 1999.

REICH, W. Escuta Zé-ninguém. Tradução de Waldéa Barcellos. São Paulo: Ed. Martins Fontes, 2007. (Trabalho original publicado em 1948).

REICH, W. Where's the truth? - Letters and journals, 1948-1957. Tradução de Derek e Inge Jordan. New York: Farrar, Strauss \& Giroux, 2012.

ROSSET, L. A crítica de Friedrich Albert Lange ao materialismo psicofísico. 2006. $76 \mathrm{f}$. Dissertação (Mestrado) - Pontifícia Universidade Católica de São Paulo, São Paulo, 2006.

SAPP, J. Genesis: The Evolution of Biology. Oxford University Press, 2003.

SCHLOEGEL, J. J.; SCHMIDGEN, H. General physiology, experimental psychology, and evolutionism: Unicellular organisms as objects of psychophysiological research, 1877-1918. Isis, v. 93, n. 4, p. 614-45, december 2002. 
SCHULTZ, D. P.; SCHULTZ, S. E. História da psicologia moderna (tradução da 9.a edição norte-americana). Tradução de M. M. Zanella, S. S. M. Cuccio. São Paulo: Cengage Learning, 2009.

SEMON, R. Mnemic psychology. Tradução de Bella Duffy. London: George Allen \& Unwin, 1923. (Trabalho original publicado em 1909).

SEMON, R. The mneme. Tradução de Louis Simon. London: George Allen \& Unwin, 1921. (Trabalho original publicado em 1904).

SERAFINI, A. The epic history of biology. New York, Perseus Publishing, 1993.

SHARAF, M. Fury on Earth. A biography of Wilhelm Reich. New York: St. Martin's Press/Marek, 1983.

STIEGLER, S. Nietzsche et la biologie. Paris: Presses Universitaires de France, 2001

TEO, T. Friedrich Albert Lange on neo-Kantianism, socialist Darwinism, and a psychology without a soul. Journal of History of the Behavioral Sciences, v. 38(3), p. 285-301, 2002.

TIXIER-VIDAL, A. De la théorie cellulaire à la théorie neuronale. Biologie Aujourd'hui, v. 204, n. 4, p. 253-66, 2010.

UEXKÜLL, J. V. Theoretical Biology. Tradução de D. L. MacKinnon. New York: Harcourt, Brace \& Company Inc.- London: Kegan Paul. Trench, Trubner \& Co., Ltd., 1926. (Trabalho original publicado em 1920).

VIRCHOW, R. L. K. La pathologie cellulaire basée sur l'étude physiologique et pathologique des tissus. Tradução de Paul Picard. Paris: J.-B. Baillière et fils, 1868. (Trabalho original publicado em 1858).

VIREY, J.-J. Philosophie de l'histoire naturelle ou phénomènes de l'organisation des animaux e des végétaux. Paris: Librairie de J. B. Baillière, 1835.

VYGOTSKI, L. S. El problema del retraso mental. In: - Obras escogidas - Tomo V. Fundamentos de defectología. Tradução de Guillermo Blank. Madrid: Ed. Visor, 1997 (Trabalho original publicado em 1935).

WAGNER, C. M. Freud e Reich - Continuidade ou ruptura? São Paulo: Summus Editorial, 1995. 
WARDEN, C. J. Animal psychology (Viewpoint and program). In: GUILFORD, J. P. (Ed.). Fields of Psychology. New York: D. Van Nostrand, 1940.

WEIDMAN, N. M. Constructing Scientific Psychology - Karl Lashley's Mind-Brain Debates. Cambridge University Press, 1999.

WELCH G. R.; CLEGG, J. S. From protoplasmic theory to cellular systems biology: a 150year reflection. American Journal of Physiology, v. 298, n. 6, C1280-C1290, June 2010.

WUNDT, W. Principles of Physiological Psychology. Tradução de Edward Bradford Titchener. 1904. [Classics in the History of Psychology]. Disponível em: < http://psychclassics.yorku.ca/Wundt/Physio/intro.htm> . Acesso em 10 out. 2011. (Trabalho original publicado em 1874). 